\title{
Handbook of Secon
Storage Batteries and Charge Regulators in Photovoltaic Systems Final Report
}

Exide Management and Technology Company 19 West College Avenue, P.O. Box 336 Yardley, Pennsylvania 19067

Prepared by Sandia National Laboratories, Albuquerque, New Mexico 87185 and Livermore, California 94550 for the United States Department of Energy under Contract DE-AC04-76DP00789

Printed August 1981

Prepared for Sandia National Laboratories under Contract No. 13-2202 


\section{DISCLAIMER}

This report was prepared as an account of work sponsored by an agency of the United States Government. Neither the United States Government nor any agency Thereof, nor any of their employees, makes any warranty, express or implied, or assumes any legal liability or responsibility for the accuracy, completeness, or usefulness of any information, apparatus, product, or process disclosed, or represents that its use would not infringe privately owned rights. Reference herein to any specific commercial product, process, or service by trade name, trademark, manufacturer, or otherwise does not necessarily constitute or imply its endorsement, recommendation, or favoring by the United States Government or any agency thereof. The views and opinions of authors expressed herein do not necessarily state or reflect those of the United States Government or any agency thereof. 


\section{DISCLAIMER}

Portions of this document may be illegible in electronic image products. Images are produced from the best available original document. 
Issued by Sandia National Laboratories, operated for the United States Department of Energy by Sandia Corporation.

NOTICE: This report was prepared as an account of work sponsored by an agency of the NOTICE: This report was prepared as an account of work sponsored by an agency of the
United States Government. Neither the United States Government nor any agency thereof nor any of their employees, nor any of their contractors, subcontractors, or their employees, makes any warranty, express or implied, or assumes any legal liability or responsibilty for the accuracy, completeness, or usefulness of any information, apparatus. product, or prosenteres by trade name, trademark manufacturer, or or herwise dol prot uct, prorily constitute imply its endorsement, recommendation, or favoring by the United States Government any a ency thereof or any of their contractors or sub an a gency herein or any Government, any agency thereof or any of their contractors or subcontractors. 


\section{Handbook of}

\section{Secondary Storage Batteries \\ and Charge Regulators in \\ Photovoltaic Systems}

\section{Final Report}

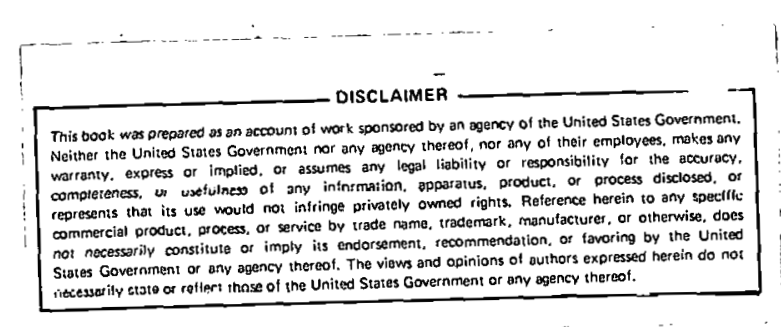

Prepared by

Exide Management and Technology Company

19 West Gollege Avenue, P.O. Box 336

Yardley, Pennsylvania 19067

Work Performed for

The U.S. Department of Energy

Sandia National Laboratories

Albuquerque, New Mexico 87185

Under Contract No. 13-2202 


\section{DISCLAIMER}

This report was prepared as an account of work sponsored by an agency of the United States Government. Neither ESB Incorporated, the United States Government, or any agency thereof, nor any of their employees, make any warranty, express or implied, or assume any legal liability or responsibility for the accuracy, completeness, or usefulness of any information, apparatus, product, or process disclosed, or represent that its use would not infringe privately owned rights. Reference herein to any specific commercial product, process, or service by trade name, mark, manufacturer, or otherwise, does not necessarily cons titute or imply $i$ ts endorsement, recommendation, or favoring by ESB Incorporated, the United States Government or any agency thereof. The views and opinions of authors expressed herein do not necessarily state or reflect those of ESB Incorporated, the United States Government or any agency thereof. 


\section{ACKNOWLEDGMENTS}

Acknowledgment is given to the following individuals who have contributed to the preparation of this handbook as authors, editors, reviewers and technical/test investigators.

Sandia National Laboratories, Albuquerque, New Mexirn

$$
\begin{aligned}
& \text { Donald M. Bugh } \\
& \text { Jay L. Chamberl in } \\
& \text { Robert P. Clark } \\
& \text { Jerry L. Watkins }
\end{aligned}
$$

Motorola, Inc., Government Electronics Division, Scottsdale, Arizona Gary Husa

Exide Management and Technology Company, Yardley, Pennsylvania
D. L. Beals
A. M. Chreitzberq
J. B. Doe
D. T. Ferrell, Jr.
J. J. Kelley
F. P. Malaspina
M. M. Sipe
t. A. Wagner

Exide Corporation 101 Gibraltar Road, Horsham, Pennsylvania

G. P. Cuuk

Exide Corporation 2510 North Blvd., Raleigh, North Carolina
A. Alexander
J. Fox 


\section{ABSTRACT}

Solar photovoltaic systems often require battery subsystems to store reserve electrical energy for times of zero insolation. This handbook is designed to help the system designer make optimum choices of battery type, battery size and charge control circuits. Typical battery performance characteristics are summarized for four types of lead-acid batteries: pure lead, lead-calcium and lead-antimony pasted flat plate and lead-antimony tubular positive types. Similar data is also provided for pocket plate nickel cadmium batteries.

Economics play a significant role in battery selection. Relative costs of each battery type are summarized under a variety of operating regimes expected for solar PV installations. 
PAGE

DISCLAIMER

ACKNOWLEDGMENTS $\quad$ ii

ABSTRACT - ․

TABLE OF CONTENTS iv

LIST OF TIGURES

LIST OF TABLES

Chapter 1

Introduction, Summary and Goals of Handbook

$1-1$

Chapter 2

General Information for Selection of

Batteries for Photovoltaic Systems

Components and Functions 2-1

Key Elements in Battery Selection 2-5

References 2-9

Chapter 3 Lead-Acid Batteries 3-1

Ceill Designi and Theory 3-1

Lead-Acid Battery Construction Types 3-2

Lead-Acid Cell Discharge Characteristics 3-9

Effect of Specific Gravity of Electrolyte and 3-14

Operating Temperature

Methods of Charging Lead-Acid Batteries 3-17

Maximum Battery Subsystem Voltage 3-21

Stratification of Electrolyte in Cells 3-24

Selection of Charge Currents $3-26$

Effect of Cell Design on Battery Life 3-31

Effect of Operating Parameters on Battery Life 3-32

Environmental Effects on Battery Life 3-34

Maintenance of Lead-Acid Batteries 3-39

Watering Cells $\quad 3-40$

Safety Precautions 3-42

Safety Rules to Avoid Chemical Burns and Shock Hazards 3-44

References $\quad 3-45$ 
TABLE OF CONTENTS (Continued)

\begin{tabular}{|c|c|c|}
\hline & & $\underline{\text { PAGE }}$ \\
\hline \multirow[t]{7}{*}{ Chapter 4} & Nickel-Cadmium Batteries & $4-1$ \\
\hline & Chemistry and Construction & $4-1$ \\
\hline & Discharge Characteristics of NiCd Cells & $4-4$ \\
\hline & Charging Characteristics & $4-8$ \\
\hline & Operating and Charged Stand Life & $4-11$ \\
\hline & Maintenance and Safety Precautions & $4-13$ \\
\hline & References & $4-15$ \\
\hline \multirow[t]{5}{*}{ Chapter 5} & Battery Costs in Solar Photovoltaic Systems & $5-1$ \\
\hline & Lead-Acid System Energy Costs & $5-3$ \\
\hline & Nickel-Cadmium System Energy Costs & $5-13$ \\
\hline & $\begin{array}{l}\text { Summary of Annual and Stored Energy Cost } \\
\text { Estimates }\end{array}$ & $5-16$ \\
\hline & References & $5-19$ \\
\hline \multirow[t]{15}{*}{ Chapter 6} & Chargers and Voltage Regulators & $6-1$ \\
\hline & Basic Voltage Regulator & $6-2$ \\
\hline & Photovoltaic System Battery Charge Control & $6-6$ \\
\hline & Series Pass Voltage Regulator & $6-9$ \\
\hline & Shunt Regulators & $6-11$ \\
\hline & Switching Regulators & $6-13$ \\
\hline & Step-Down Series-Switch Converter/Regulator & $6-15$ \\
\hline & Stcp-Up Shunt Switch Converter/Regulator & $6-18$ \\
\hline & Comparison of Voltage Regulators & $6-23$ \\
\hline & Series-Pass Voltage Regulator & $6-24$ \\
\hline & Shunt Voltage Regulator & $6-25$ \\
\hline & Step-Down Series Switch Regulator & $6-27$ \\
\hline & Step-Up Shunt Switching Regulator & $6-28$ \\
\hline & Cost/Performance Trade-0ffs & $6-30$ \\
\hline & References & $6-32$ \\
\hline
\end{tabular}


TÁBLE OF CONTENTS (Continued)

PAGE

Chapter 7

Selection of Battery for Photovoltaic System

Shallow Cycle Service

Deep Cycle Service

$7-1$

Standby Service Versus Cycle Service

$7-2$

Application Data Summary Forin

$7-6$

Appendi $\ddot{A}$

Typical Performance lharacteristics of

Appendix A-1

Lead-Acid Cells and Batteries

$A-1-1$

Pure Lead Charge Retaining Batteries (110$600 \mathrm{Ah})$

Appendix A-2

Lead-Calcium Pasted Flat Plate Cells (50-200 Ah)

Appendix A-3 Lead-Calcium Pasted Flat Plate Cells (1850-3700 Ah)

Appendix A-4 Lead-Antimony Pasted Flat Plate Cells (50-200 Ah)

$A-2-1$

$A-3-1$

$A-4-1$

Appendix A-5 Lead-Antimony Pasted Flat Plate Cells (110-900 Ah)

Appendix A-6

Lead-Antimony Tubular Positive Cells and

$A-6-1$ Batteries (220-1820 Ah)

Appendix B

Typical Performance Characteristice of Nickel-Cadmi um Pocket Plate Cells

Appendix B-1

Typical Performance Rharacteristics of Nickel-Cadmi um Pockct Plate Cells 


\section{LIST OF FIGURES}

Figure

$\underline{\text { Title }}$

Page

Components of Solar Photovoltaic System

Solar Array vs. System Load Power Requirement

Manchex Type

Tubular Positive Type

Flat Pasted Plate

Effect of Discharge Rate on Output at $25^{\circ} \mathrm{C}$

Effect of Discharge Temperature Rate and Specific Gravity on Output Capacity

Effect of Discharge Rate and Temperature on $25^{\circ} \mathrm{C}$ Discharge Capacity

Effect of Depth of Discharge and Number of Cycles per Year on Wet Life, $25^{\circ} \mathrm{C}$.

Relative Local Action of Cells of Different Construction

3-11 Effect of Cel1 Temperature on Capacity Loss During Charged Stand (Pure Lead Charge Retaining Cells)

Effect of Discharge Rate on Capacity and Voltage Regulation

Effect of Operating Temperature on Discharge Capacity 


\section{LIST OF FIGURES (Continued)}

Figure

Title

Page

5-1 Shallow Cycle Life of Low Rate, Pure Lead Flat

Plate Cells, Charge Retaining Type, 110-600 Ah

Size Range

6-1 Basic Regulator Block Diagram 6-3

6-2 Control Element Configurations 6-5

6-3A Ce11 Vullage and Current Buring Charqe $6-6$

6-3B Typical Solar Array Current vs. Voltage Output 6-7

6-4 Basic Series - Pass Voltage Regulator. $Q_{7}$ is an 6-10 Electronically Controlled Variable Resistance in Series with the Load

6-5 Bäsic Shunt Regulator $6-12$

6-6 Basic Switching Regulators 6-13

6-7 (a) Swi Luhing Vul Laye Converter Average Output b-16 Vol tage

(b) Switching Voltage Converter with LC Filter and Diode

A Shunt Switch Voltage Step-Up Converter

$6-19$

6-8B Addition of a Feedback Loop to Build a Step-Up 6-22 Switching Converter

A-1-1 Discharge Vol tage vs. Percent Time to End Voltage, 11 to 500 Hour Discharge Rate, 110, 220, and bü Ah iells, 1.3́u Specitic liravity, $25^{\circ} \mathrm{C}$

A-7-2 Energy Density per Unit Weight, Charge Retaining 110,220 and 600 Ah Cells vs. Discharge Rate, $10-500 \mathrm{~h}, 25^{\circ} \mathrm{C}$

A-1-3 Energy Density per Unit Volume, Charge Retaining 110,220 and 600 Ah Cells vs. Discharge Rate, $10-500 \mathrm{~h}, 25^{\circ} \mathrm{C}$ 


\section{LIST OF FIGURES (Continued)}

Figure

Title

Page

A-2-1

Cell Voltage vs. Percent Time to Final Voltage

$A-2-3$ of 50-200 Ah Cells at $25^{\circ} \mathrm{C}, 1.215$ Specific Gravity Sulfuric Acid

A-2-2 Energy Density per Unit Weight vs. Discharge Rate (Hours) at $25^{\circ} \mathrm{C}, 50-200$ Ah Cells, 1.215

$A-2-3$ Specific Gravity Acid

Energy Density per Unit Volume vs. Discharge Rate (Hours) at $25^{\circ} \mathrm{C}, 50-200$ Ah Cells, 1.215

$A-2-3$

Specific Gravity Acid

A-3-1 Discharge Cell Voltage vs. Percent of Time to 1.75 Volts End Voltage, $1,3,8$ and 500 Hour. Discharge Rate, $25^{\circ} \mathrm{C}$

A-3-2 Energy Density per Uni.t Weight vs. Discharge Rate, $1-500$ Hours, $25^{\circ} \mathrm{C}$

A-3-3 Energy Density per Unit Volume vs. Discharge Ra te, $1-500$ Hours, $25^{\circ} \mathrm{C}$

$A-3-3$

A-4-I Discharge Voltage vs. Percent Time to End
Voltage of 1.75 Volts at 1,8 and 500 Hour

$A-3-3$

A-4-I Discharge Voltage vs. Percent Time to End
Voltage of 1.75 Volts at 1,8 and 500 Hour Rate, $25^{\circ} \mathrm{C}$

A-4-2 Energy Density per Unit Weight vs. Discharge Rate, Hours, $25^{\circ} \mathrm{C}$

$A-4-3$

A-4-3 Energy Density per Unit Volume vs. Discharge A-4-4 Rate, Hours, $25^{\circ} \mathrm{C}$

A-3-3

$A-4-3$

Wet Life and Cycle LIfe vs. \% Depth of Discharge, A-4-4 $25^{\circ} \mathrm{C}$

A-6-1 Discharge Voltage vs. Percent Time to End Voltage A-6-2 of 1.75 Volts per Cell at $25^{\circ} \mathrm{C}$ at 1,8 and 500 Hour Discharge Rate

A-6-2 Wet Cycle Life vs. Percent Depth of Discharge, 200- A-6-2 400 Ah Tubular Positive Cells, 1.28 Specific Gravity, $25^{\circ} \mathrm{C}$ 


\section{LIST OF TABLES}

Table

Title

Page

$3-1$

Ce.11 Discharge Characteristics

3-2 Freezing Points of Sulfuric Acid Electrolyte

3-3 Correction Factors for Cell Gassing Voltage

$3-4$

Battery Subsystem Voltage vs. System Window (200 - 300 Volts)

Effect of Age of Lead-Anti
Charge Current and Voltage

Effect of Discharge Depth, Initial Charge Rate at 2.39 VPC and Finishing Rate on Charge Time

3-7 Effect of Initial Charge Current and Constant Potential on Charge Time for 60 and $80 \%$ Depth of Discharge 
Table

Title

Page

$5-6$

Energy Output, Delivered and Stored Energy

$5-10$ Cost 220-770 Ah Lead-Antimony Tubular Positive Motorized Truck Cells

Energy Output, Delivered and Stored Energy Cost 760-2130 Ah Lead Antimony, Tubular Positive General Purpose Cells

Energy Output, Deliyered and Stored Energy Cost 225-1200 Ah Lead-Antimony, Pasted Flat Plate Motive Power Cells

Energy Output, Delivered and Stored Energy Cost 6 Volt Electric Vehicle Type Lead-Antimony Flat Plate Batteries

NiCd Pocket Plate Ce1]. Output Energy and Stored Energy Costs vs. Discharge Rate

5-11A Summary of Battery Subsystem Annual and Stored Energy Costs Lead-Acid System

$5-14$

Summary of Battery Subsystem Annnual and Stored Energy Costs Nickel-Cadmium System

Normalized Cost/Performance Trade-0ffs

Discharge Energy Output vs. Discharge Rate 600 Ah Low Rate Charge Retaining Cel1, $25^{\circ} \mathrm{C}$ Temperature Lead-Calcium Flat Plate Cells 50-200 Ah

A-3-1 Energy Density vs. Discharge Rate and Operating A-3-2 Temperature Lead-Calcium Flat Plate Cells 1020-3700 Ah

A-4-1 Energy Output and Energy Density per Unit Weight A-4-2 and Volume at $-18,0$ and $25^{\circ} \mathrm{C}$ vs. Discharge Rate 1,8 and 500 Hours to 1.75 Volts per Cell, 50-200 Ah Cells 


\section{LIST OF TABLES (Continued)}

Table

Title

$\underline{\text { Page }}$

$A-5-1$

Discharge Voltage vs. Discharge Rate and Depth A-5-2 of Discharge, Motive Power Ce11s, $25^{\circ} \mathrm{C}$.

$A-5-2$

Energy Output, Energy Density vs. Discharge

$A-5-3$

Rate, 3, 8, and 72-Hours, Motive Power Cc11s, $25^{\circ} \mathrm{C}$.

A-5-3 Wet Lifc and Cyele Life vs. Depllh uf D1scharge, A-5-4 Motive Power Cells, $25^{\circ} \mathrm{C}$.

A-5-4 Discharge Capacity, Energy Output, and Energy A-5-5 Density, $25^{\circ} \mathrm{C}, 6$ Volt Electric Vehicle Type Batteries

A-6-1 Energy Output 6-Hour Rate, Energy Density vs. A-6-1 Operating Temperature, $-18,0$ and $25^{\circ} \mathrm{C}$ for 12 V Motorized Hand Truck Batteries.

$A-6-2$

Energy Output, Average $\mathrm{Vn} ! \mathrm{tage}$, Energy Density $A=G=\hat{\imath}$ vs. Discharge Rate, $7,8,100$ and 500 Hours $25^{\circ} \mathrm{C}$ General Purpose Tubular Positive Cells, 760-1820 Ah.

A-6-3 Energy Output, Energy Density vs. Discharge A-6-5 Rate 6,12 and 72 -Hours, $25^{\circ} \mathrm{C}$. Tubular Positive Motive Power Ce17s, 510-1200 Ah.

A-6-4 Wet Life and Cycle Life vs. Depth of Discharge, A-6-6 Tubular Positive Industrial Truck Cells, $25^{\circ} \mathrm{C}$.

$B-1-1 \quad$ Discharge Voltage vs. Discharge Rate and Depth $B-1-2$ of Discharge, $25^{\circ} \mathrm{C}$.

B-7-2 Charge Efficiency of Pocket'Plate Nickel- B-1-2 Cadmi uiii Ce 11 is, $25^{\circ} \mathrm{C}$.

B-1-3 Energy Output, Energy Density vs. Discharge B-1-3 Rate, $.1,5,10,50,500$ Hours, 7.5-480 Ah Cells, $25^{\circ} \mathrm{C}$.

B-1-4 Charged Stand Loss Rates at 22 and $49^{\circ} \mathrm{C}$. B-1-4 


\section{CHAPTER I}

INTRODUCTION, SUMMARY AND GOALS OF HANDBOOK

Work Performed for

The U.S. Department of Energy

Sandia National Laboratories

Albuquerque, New Mexico 87185

Under Contract No. 13-2202 


\section{CHAPTER 1 \\ INTROOUCTION, SUMMARY AND GOALS OF HANDBOOK}

Harnessing energy from the sun to perform useful work is becoming more and more urgent, perhaps one of the most important priorities for the eighties. The direct conversion of the sun's insolation to electrical current is no longer a scientific curiosity but a practical way to generate auxiliary power for electrical devices in remote locations with no access to a utility grid.

Photovoltaic systems composed of solar photovoltaic cells in panels, voltage control circuits and batteries for energy storage can now be the major power source for navigational aids, village electrical power, water pumping, communication devices, TV stations and homes.

The major purpose of this handbook is to collect some of the essential information needed by the photovoltaic system designer as an overview of the requirements for the battery energy storage subsystem and its charge control equipment. This handbook provides technical data to enable the photovoltaic system designer to select the battery type and size best suited to meet the specifications for each application and to predict how the battery subsystem will operate under each set of conditions:

Brief descriptions are given of four types of lead-acid batteries and one type of nickel-cadmium battery available from commercial sources today. 
Discharge characteristics are given for each battery type, and the effects of discharge rate; discharge depth and operating temperature are illustrated with tables of data and graphs. Optimum charging methods are recommended to meet operating requirements and to extend 1 ife. The effects of cell design and operating conditions on battery life are outlined to aid the solar PV system designer in battery selection.

Remote solar PV installations require battery subsystems with minimum maintenance because of the extreme costs associated with transporting personnel and parts by helicopter to each site. Minimum maintenance requirements are therefore recommended for each battery type, and safety precautions advised for personnel who install and maintain the systems.

Estimates are given of battery purchase prices based on GSA approved catalog prices for late 1980. Delivered energy costs are calculated in dollars per kilowatt-hour for single dischargess at various rates from the 1-hour to the 500-hour rate. Energy storage costs are estimated using cycle lives consistent with actual test and operational experience in non-solar PV system applications. This battery cycle cost covers all cycles during the life of the battery and has units of dollars per kilowatt-: hour per cycle.

The relative economic viability of each of the four types of lead-acid batteries and one type of nickel-cadmium battery can be compared under a variety of test conditions. 
The operation of four types of voltage regulator circuits is explained. A comparison of the characteristics of each circuit is made to aid the designer in selecting a circuit most favorable to each application. The impact of their charge control on the battery is given in terms of the trade-off of initial vs. long term performance, voltage control vs. life, energy storage efficiency and maintenance.

Finally, the process of engineering a particular battery into a solar photovoltaic system is described in terms of the minimum essential information required by the designer to match a battery design to a given solar PV system design.

Technical information on batteries which are commercially available is collected in the appendix so that the designer can become aware of their performance characteristics. Using this data and the handbook, the solar PV system designer should be able to work intelligently with the battery manufacturer's sales and applications engineers to select the optimum battery type, a capacity to assure adequate energy storage, and a cell design to provide the required years of wet life. 


\section{CHAPTER 2}

GENERAL INFORMATION FOR SELECTION OF BATTERIES FOR PHOTOVOLTAIC SYSTEMS

- Components and Functions

- Key Elements in Battery Selection

Work Performed for

The U.S. Department of Energy Sandia National Laboratories Albuquerque, New Mexico 87185 Under Contract No. 13-2202 


\section{CHAPTER 2}

\section{GENERAL INFORMATION FOR SELECTION OF BATTERIES FOR PHOTOVOLTAIC SYSTEMS}

Photovoltaic systems are designed to perform the following functions:

- Convert solar energy to direct current

- Regulate the electrical energy output

- Feed the electrical energy into an external load circuit to perform work, ior

- Store the electrical energy in a battery subsystem for later use.

Photovoltaic systems are designed for many applications varying in size and complexity. Some are isolated from ac power lines. Remote systems include navigational aids along coastlines; beacons on mountain peaks, and isolated villages in developing countries. Some photovoltaic systems have ac power or diesel electric generators as a source of auxiliary electric power. Systems have been designed for water pumping stations, for supplying power to TV and communication equipment, village power, auxiliary power for heating and cooling private homes and industrial applications.

\section{COMPONENTS AND FUNCTIONS}

A block diagram of a typical system is shown in Figure $2-1$ to identify the components and their functions. The key components are the solar panel, the voltage regulator, the storage battery, the dc-ac inverter (or dc to dc converter), and the load. 


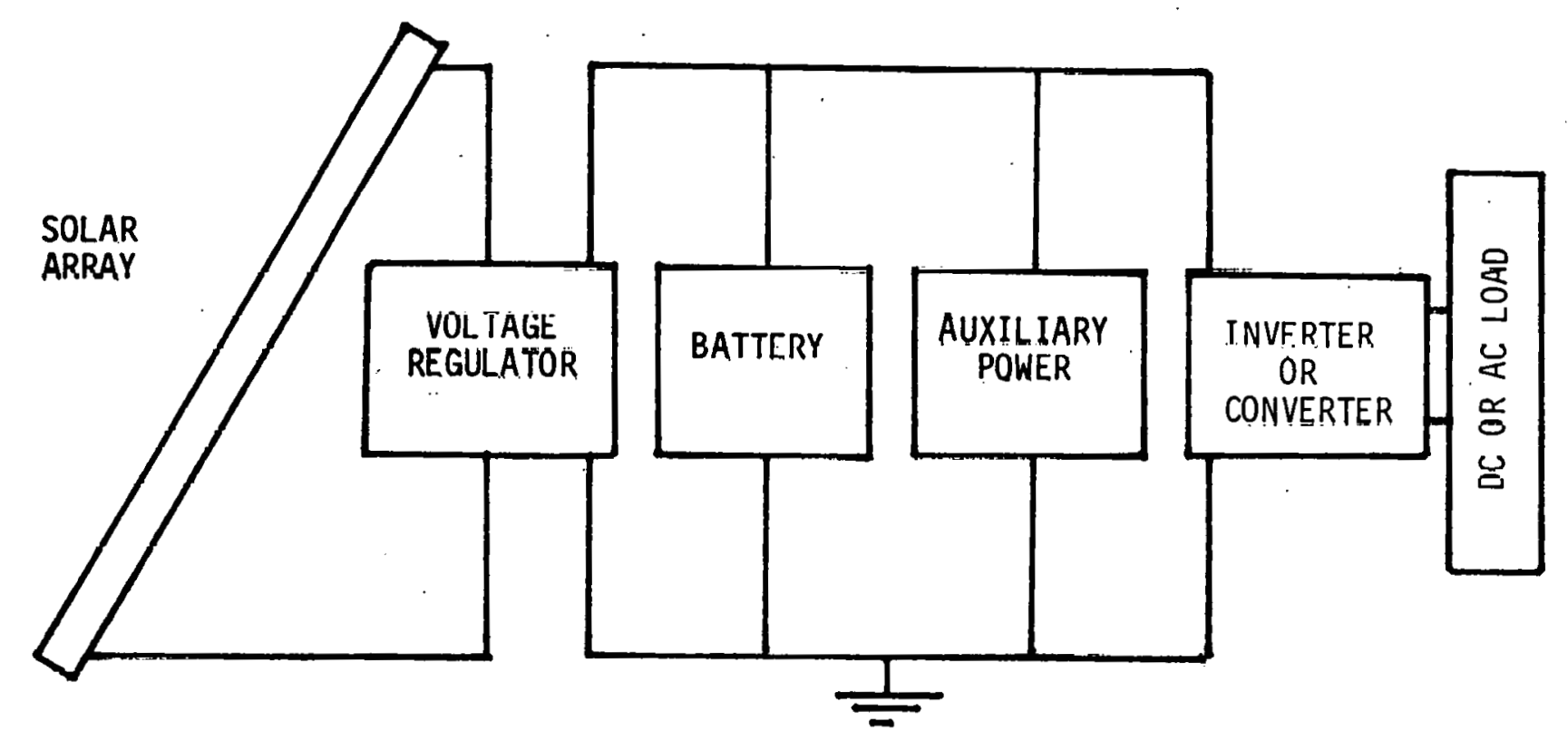

Figure 2-1 Components of Solar Photovol taic System 
Solar panels are an orderly arrangement of solid state solar photovoltaic cells in series and parallel strings which convert incident solar energy into direct unregulated current. Panel electrical performance is normally described by $i$ ts characteristics delivered under maximum sunlight:

- Peak power

- Voltage at peak power

- Current at peak power

- Short circuit current

- Open circuit voltage

Incident sunlight, or insolation, varies constantly during the day and with geographical location. Panel output therefore also varies and must be regulated by the voltage regulator to control the current and the vol tage of electrical power delivered to the external load or the battery subsystem to be stored. Excessive current and voltage delivered to the battery is a major reason for short battery life.

The dc-ac inverter changes $d c$ power from either the solar panel or the battery to ac power to perform work in ac loads (motors, transmitters, lights, etc.). A dc-dc converter can be used if the load is designed for dc power. 
At night and during continuing overcast days, the energy stored in the battery subsystem can be depleted. When the discharging battery voltage drops below a predetermined value, the auxiliary dc power supply cuts in to carry the load and recharges the battery as specified by the battery manufacturer.

In the simplest stand-alone system, the only components which may appear to be needed are the solar panel, the battery and the dc load. The battery is sized to accept the highest power output from the solar panel wi thout overcharge damage. In most cases, however, insolation is not that predictable, and the panel output varies over such a wide range that voltage regulators are needed and recommended to regulate power flowing to the battery. A low voltage disconnect is also recommended to protect the battery from overdischarge.

The battery subsystem stores excess energy generated by the solar panel during bright days of high insolation and discharges this stored energy back into the load at night or on overcast days. For a continuous power output capability, the battery is a very essential component. Batteries can be selected to give a much wider range of output than the solar panel to provide:

- High peak energy for starting motors or engines

- For opening and closing circuit breakers

- For steady current output for long periods of time 
In addition, the battery can repeat these functions through many charge-discharge cycles within a wide temperature range during its long life. Correct battery selection is therefore most important to the success of the solar photovoltaic system.

\section{KEY ELEMENTS IN BATTERY SELECTION}

Selection of the proper battery for a solar photovoltaic system requires a complete analysis of the battery discharge requirements. The kilowatt-hours of energy stored in the battery will depend upon the load requirements, the number of days of storage, the insolation patterns in the geographical area of the installation and the solar panel output. 0ther factors in sizing the battery are operating temperature variations, environmental temperature extremes and daily ranges, the voltage regulator efficiency, and the efficiency of the inverter.

The energy required to charge a battery will be the sum of the previous discharge energy output and the energy expended as work and excess heat during the recharge. Longer charge times and lower charge currents tend to increase charge efficiency. In lead-acid batteries, turn around energy efficiency can approach 85 percent. Shorter charge times and higher charge currents will sacrifice energy efficiency and battery life. Charge time and power available from the solar panel-regulator subsystem must therefore be considered in selecting the battery type and size. 
The analysis of the application requirements must include a review of the following performance parameters:

- The minimum and maximum operating voltage of electronic equipment, battery and components of the load: i.e., the voltage window

- The power cycle including all sequences of charge and discharge

- The power output profile of the photovoltaic panel predicted at the site under the prevailinq insolation patterns.

Charging power at voltages up to the maximum voltages at top-of-charge required by the battery must be available from the voltage regulator sufficiently long during each charge period to maintain the battery in the charged state. If charging voltages are set too low, recharge time will be greatly extended or, in the worst case, recharge will not be completed. The minimum voltage in the window will be the lowest voltage delivered by the battery during discharge, and the voltage at which auxiliary power will be cut into the system to recharge the battery, or the voltage at which the battery will disconnect from the lnad. This voltage window determines the number of solar cells in series in the photovoltaic panel and the number of battery cells in series in the battery subsystem.

A study of the power requirements of the system duty cycle must establish each current, time, and power level for all sequences and for each component in the system load. 
A corresponding study of the photovoltaic panel output must establish the sequential pattern of power output and duration expected on site for the full period of system operation and not less than one year. Seasonal variations may show, as in Figure 2-2, that excess power may be expected during high insolation months but that; in some months, the power required by the anticipated load can exceed power available from the solar panel. Unbalance of power requirements of this kind must be corrected by increasing the panel size, by power conservation in the load, or by use of an auxiliary power source.

From the analysis above, considerations must establish:

- The size of the photovoltaic panel required to provide the energy for the load and for recharging the battery subsystem

- The recharging time and power available

- The size of the battery required for energy storage, i.e., number of cells in series and parallel, the individual cell capacity, the subsystem storage energy in kilowatt-hours and capacity in ampere-hours.

Battery cell type, plate and separator designs must then be selected in consultation with the sales engineers representing the battery manufacturer. Cell design must. match the highest charge and discharge rates and the extremes in operating temperature predicted for the battery under conditions at each site. The battery manufacturer must provide operating voltage data to assure the system designer that the required capacities are delivered within the specified acceptable voltage range 


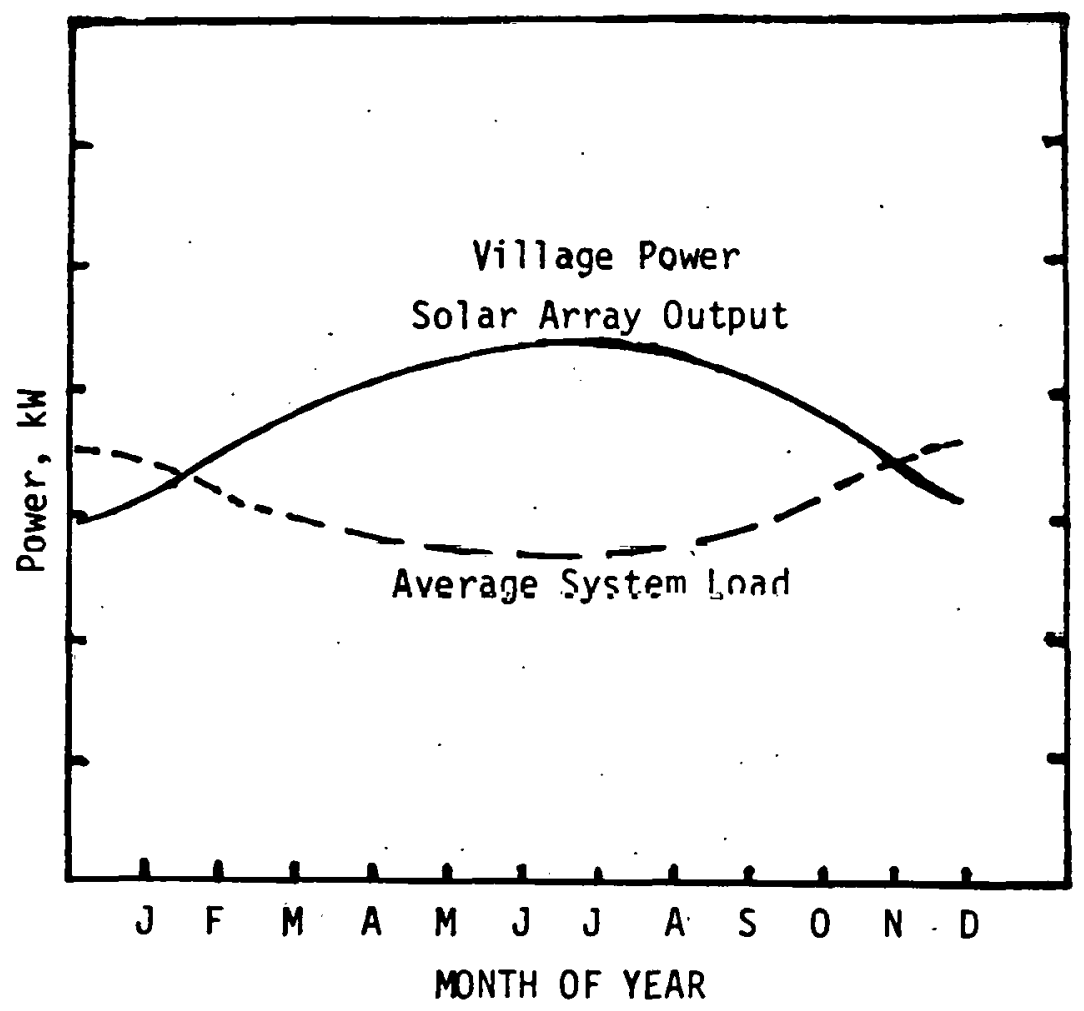

Figure 2-2 Solar Array vs. System Load Power Requi rement (2-1)

for each load period in the duty cycle. The battery manufacturer can select from the product line cells with most desirable number of plates, plate thickness, active material density, plate grid design, electrolyte conductivity and separator system to control cell and battery performance.

Battery maintenance must also be considered. To visit remote installations for the purpose of system or battery maintenance can require a.substantial transportation and labor cost. Maintenance-free or reduced maintenance batteries are attractive in these applications if. other performance attributes are also demonstrated. Replacement of water loss from overcharge electrolysis of battery electrolyte is the major task of maintenance in vented batteries, both lead-acid and nickel-cadmium. Other tasks are keeping intercell and inter-row battery connections tight 
and the battery clean and dry. Maintenance can be scheduled from a knowledge of the overcharge in the duty cycle and the number of cycles per week.

Battery operating life in the solar PV system is a function of the operating temperature, the duty cycle, the charge control and the cell design. Significantly higher average operating temperature decreases life, and the number of charge-discharge cycles decreases with increasing depth of discharge.

In general, longer-life batteries have a higher initial cost. Replacing a battery, especially a very large array of cells, can be a substantial element in storage battery costs. Economic studies should be made to reflect the sum of initial battery price, installation costs, operating and maintenance costs, and the cost of replacement. The overall price of a long-life battery may be less than the price of two shorterlife batteries when all factors are considered. The battery manufacturer can provide an estimate of the operating life of each battery type on the market when the operating time-temperature and duty cycles are well known.

\section{REFERENCES:}

2-1 B. L. Grossman, B. L. Brench, L. L. Bucciarelli, F. J. Solman, Simulation of the Performance of a $100 \mathrm{~kW}$ Peak Photovoltaic System, Massuchusetts Inst. of Tech., Lexington, Mass. 1980, C00-4094-71. 


\section{CHAPTER 3}

LEAD-ACID BATTERIES

- Cel1 Design and Theory

- Lead-Acid Battery Construction Types

- Manchex Type

- Tubular Positive Type

- Flat Pasted Plate Type

- Lead-Acid Cell Discharge Characteristics

- Effect of Specific Gravity of Electrolyte and Operating Temperature

- Methods of Charging Lead-Acid Batteries

- Maximum Battery Subsystem Voltage
- Stratification of Electrolyte in Cells

- Selection of Charge Currents

- Effect of Cell Design on Battery Life

- Effect of Operating Parameters on Battery Life

- Environmental Effects on Battery Life

- Safety Rules to Avoid Chemical Burns and Shock Hazards

- Maintenance of Lead-Acid Batteries

- Equalization

- Watering Cells

- Safety Precautions

- References

Work Performed for

The U.S. Department of Energy

Sandia National Laboratories

Albuquerque, New Mexico 87185

Under Contract No. 13-2202 


\section{CHAPTER 3}

\section{LEAD-ACID BATTERIES}

In this chapter the solar photovoltaic system designer can obtain a brief summary of the electrochemical reactions in an operating lead-acid battery, various construction types, operating characteristics, design and operating procedures controlling life of the battery, and maintenance and safety procedures.

\section{CELL DESIGN AND THEORY}

In a lead-acid cell the active materials are lead dioxide $\left(\mathrm{PbO}_{2}\right)$ in the positive plate, sponge lead (Pb) in the negative plate, and a solution of sulfuric acid $\left(\mathrm{H}_{2} \mathrm{SO}_{4}\right)$ in water as the electrolyte. The chemical reaction during discharge and recharge is normally written:

$$
\mathrm{PbO}_{2}+\mathrm{Pb}+2 \mathrm{H}_{2} \mathrm{SO}_{4} \underset{\text { Charge }}{\stackrel{\text { Discharge }}{\rightleftarrows}} 2 \mathrm{PbSO}_{4}+2 \mathrm{H}_{2} \mathrm{O}
$$

This reaction gives the ideal proportions by weight of the reactants to deliver capacity at a very low discharge rate when the amounts of $\mathrm{PbO}_{2}$, lead and sulfuric acid would be simultaneously depleted to zero. In actual practice the reactions during discharge are not carried to completion, and the theoretical capacity 26.805 Ah per chemical equivalent of reactant is never delivered. 
Life is limited normally by the positive plate which is least efficient. An excess of negative active material $(\mathrm{Pb})$ is designed into the negative plate to extend wet life and cycle life. An excess of sulfuric acid is also present in the electrolyte in most cells to maintain proper acidity for long life.

As discharge continues, cell internal resistance increases and the cell voltage falls to an unusable value before more than $30=40$ percent. of the limiting positive active material is converted from $\mathrm{PbO}_{2}$ to $\mathrm{PbSO}_{4}$.

In each cell the manufacturer attempts to reduce excess or reserve active materials to control cost. In many applications the cell designer has a goal of maxiumum energy output per unit weight and per unit volume of total cell. Consequently, some cell designs may become acid limited if the discharge rate is at an amperage below the anticipated cell design range.

\section{LEAD-ACID BATTERY CONSTRUCTION TYPES}

Lead-acid battery types which are now commercially available are classified by type of positive plate:

- Manchiex

- Tubular positive plate

- Pasted flat plate 
The alloy used in the positive plate grid varies and is responsible for the following sub-types: (1) lead-antimony; (2) lead-calcium; and (3) pure lead. Lead-antimony cells are recommended for applications requiring very long life under cycling regimes discharging to depths greater than $20 \%$ of their rated capacity. Lead-calcium and pure lead cells are recommended for float and shallow cycling service where average discharge depth is less than 20\%. Pure lead alloy cell types are used when very low charged stand loss is a requirement in the application and occasional deep cycles are expected. Negative plates in all lead-acid cells are the flat pasted type.

\section{Manchex Type}

The Manchex type is shown in Figure 3-1. The grid is cast with low antimony lead alloy. The button or rosette is a pure lead ribbon which is serrated and rolled into a spiral form. These in turn are pressed or wedged into the holes of the grid. The surface of the buttons is oxidized to $\mathrm{PbO}_{2}$ for the positive active material.

The grid is quite heavy and therefore gives long life, particularly in standby type service with moderate cycling such as railroad signal and utility application. A life of 25 years is normal for utility operation. 


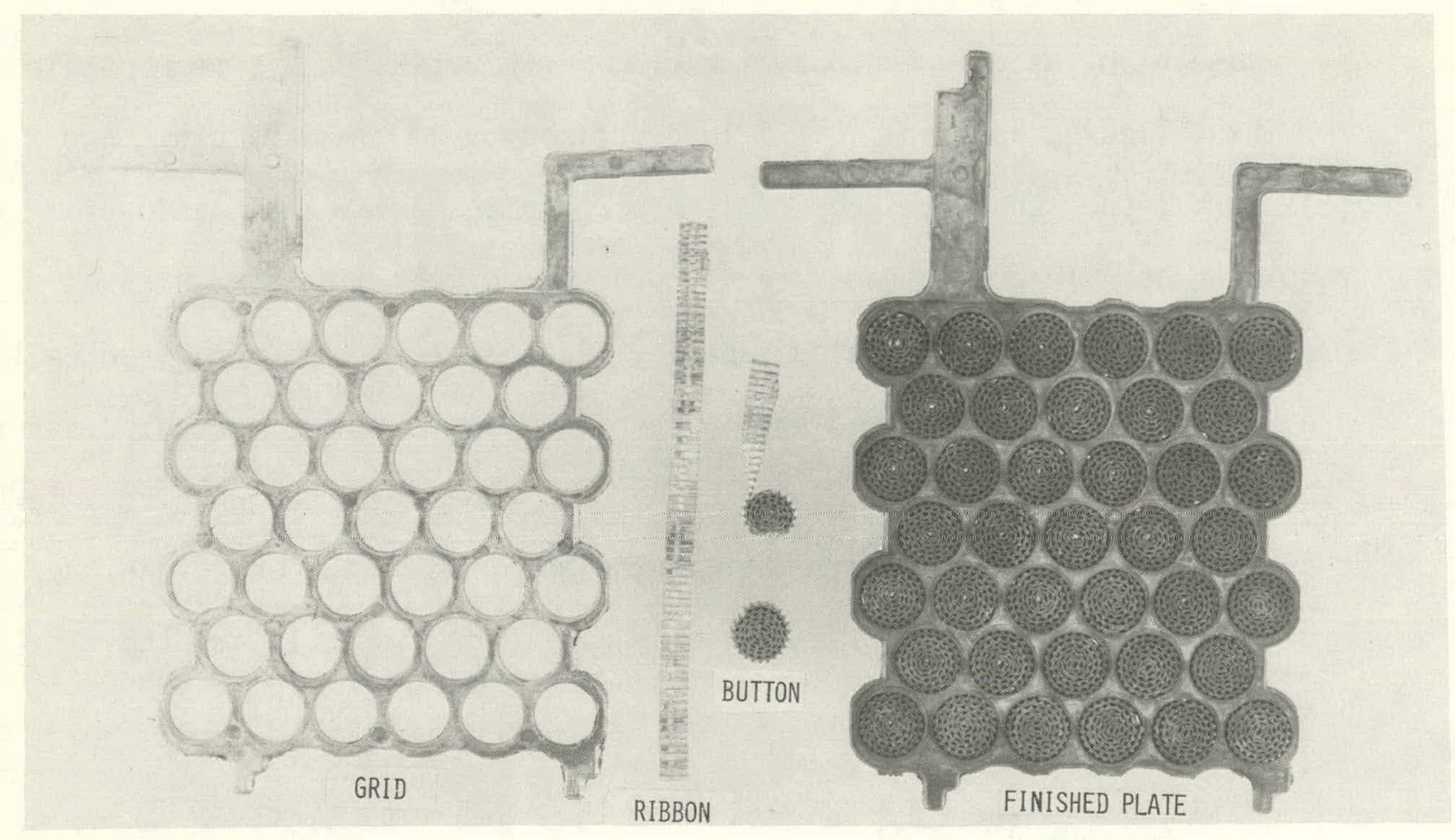

Figure 3-1 - Manchex Type

Tubular Positive Type

This plate construction is shown in Figure $3-2$. The grid, which is the current conducting member, is a series of low antimony lead spines. Woven or porous plastic or glass material is used for the tubing which is centered on each spine. Then the active material is added and the ends are sealed.

This type of battery is generally used in lift truck and material handling applications where deep cycling routines require an average discharge depth of 70 to 80 percent of the 6 -hour rated capacity and recharge within an 8-hour period. Battery life is about six years in a lift truck application requiring an $80 \%$ depth discharge each working 
day 250 days per year, or 1500 cycles. Tubular positive batteries are also used for on-the-road diesel starting. In Europe they have wide use in utility switch gear. In $20 \%$ depth, shallow cycling regimes 4,000 or more cycles can be obtained when multi-cycles per day are performed.

The tubular positive battery gives excellent discharge performance from diesel starting rates to the 24-hour rate. It has excellent high rate charging characteristics, good standby life, and is a very versatile cell type.

Tubular batteries are normally produced in one plate thickness. Variations in capacity are obtained by increasing the number of tubes per plate and/or by varying the tube (or plate) height. 


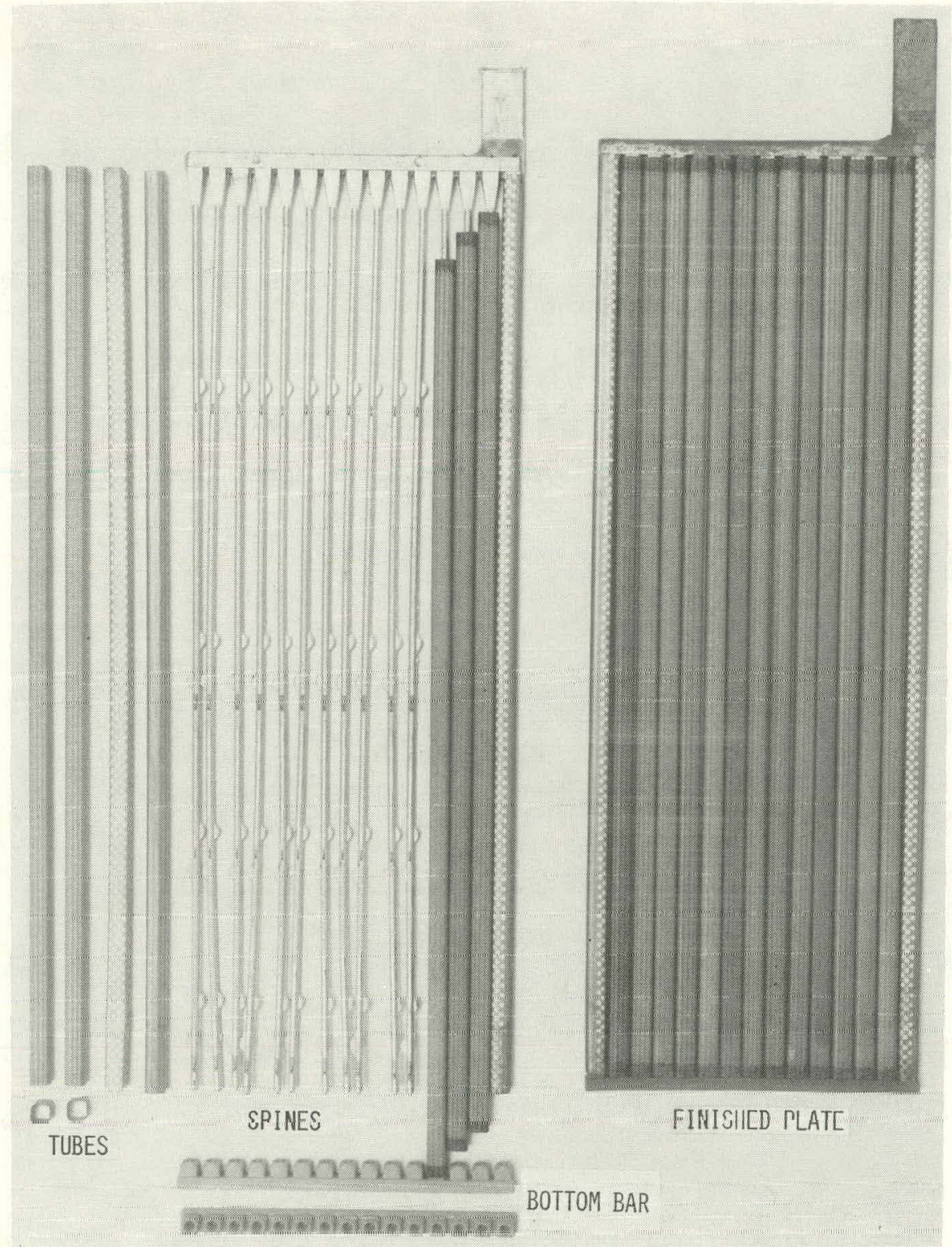

Figure 3-2 - Tubular Positive Typc

\section{Flat Pasted Plate Type}

A typical pasted plate construction is shown in Figure $3-3$. lattice grid is cast with pure lead, lead-calcium or lead-antimony depending on the size of the plate and the application. Active material is applied as a wet paste and the plate is then cured, dried and formed. 
When used in repetitive deep cycle operation, such as fork lift truck handling, glass mats and a perforated plastic retainer are wrapped around the positive plate to minimize the loss of positive active material and to obtain good cycle life. This wrap performs the same function as :he retainer tube of tubular nositive plates.

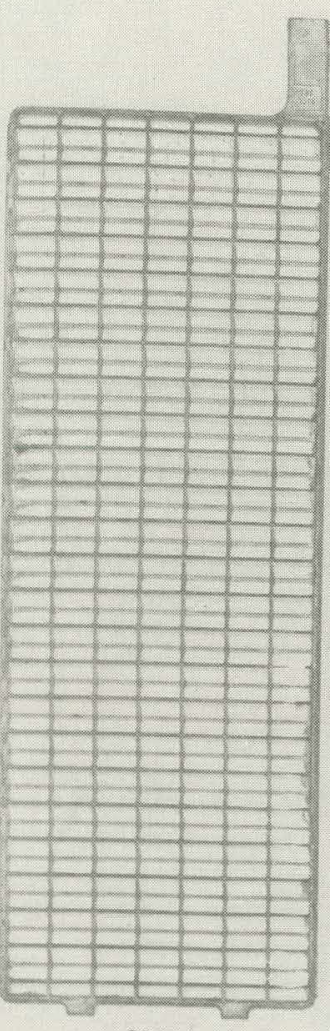

GRID

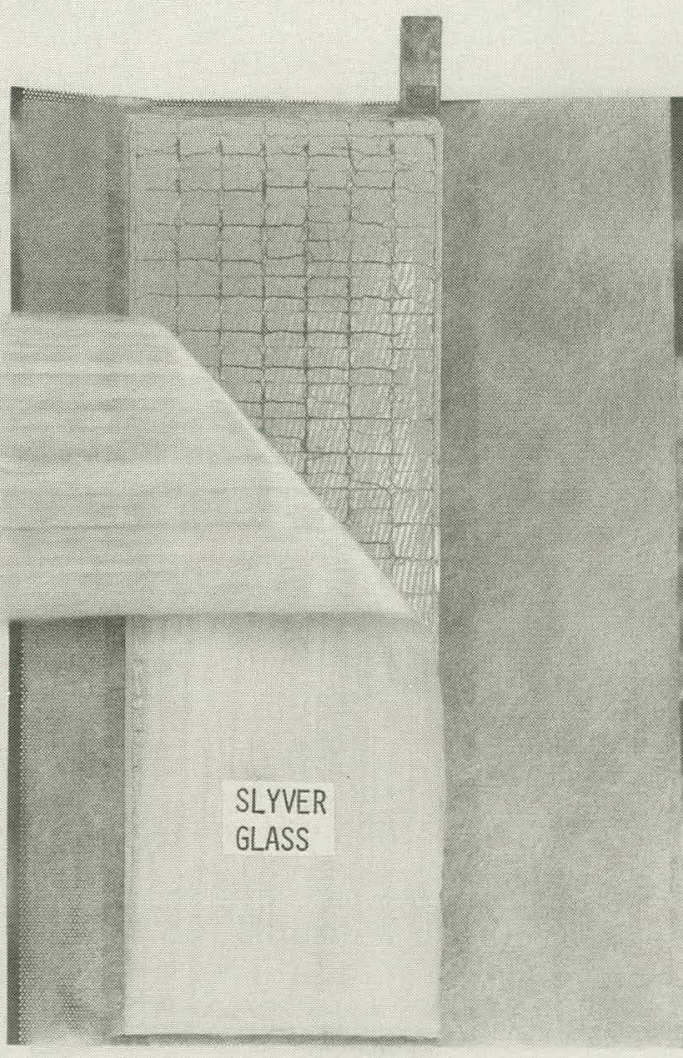

PARTIALLY WRAPPED PLATE

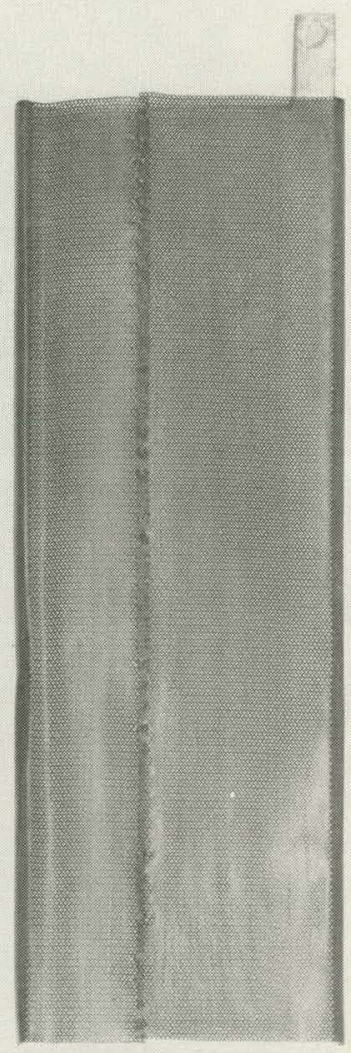

FINISHED PLATE

Figure 3-3 - Flat Pasted Plate

During the last stages of charge, oxygen gas is formed at the surface of positive plates. The agitation of gas bubbles streaming from the surface of exposed grid and active material tends to erode the active 
material which is shed through the glass retainer and settles into the sediment space at the bottom of each cell.

In light cycle or in float service this positive active material shedding is not the major failure mechanism. In these applications the glass mat retainer is lighter, thinner, and the perforated outer wrap is nmi t.t.rd.

Both designs depend upon a ribbed microporous separator adjacent the negative plate to achieve longest 1 ife. (3-4) $^{(3-4)}$

Pasted plates are made with thin or thick grids depending on the application. In general, when the application demands a high ampere rate for a very short time, it is customary to use many thin plates in a container. Thicker plates with fewer plates per container are used for those applications with relatively low ampere drain for relatively long periods of time. In general, when the service is similar, thin plates will give less life than thick plates.

Lead-antimony grids are usually used for daily deep cycle operation. Grids with a lead-calcium alloy or pure lead can also be cycled; but repetitive cycles are restricted to a depth less than $20 \%$ plus infrequent operations with a discharge depth as high as $50-60 \%$ of the 6 -hour to 8-hour rated capacity. 
The real advantage to cells with lead-calcium and pure lead positive grids is in standby operation when long periods of float are expected between power outages and discharge cycles. During these periods the cells are maintained at a constant charge voltage, and the charge current required to maintain lead-calcium and pure lead positive grid cells at voltage is much lower than the lead-antimony grid. A reduction in float charge current reduces water loss and the maintenance cost of adding water to battery cells.

\section{LEAD-ACID CELL DISCHARGE CHARACTERISTICS}

In the lead-acid system the average voltage during discharge, the capacity delivered, and the energy output are dependent upon the discharge current. A typical example is given in Figure 3-4.

[Figure and text continued on the following page] 


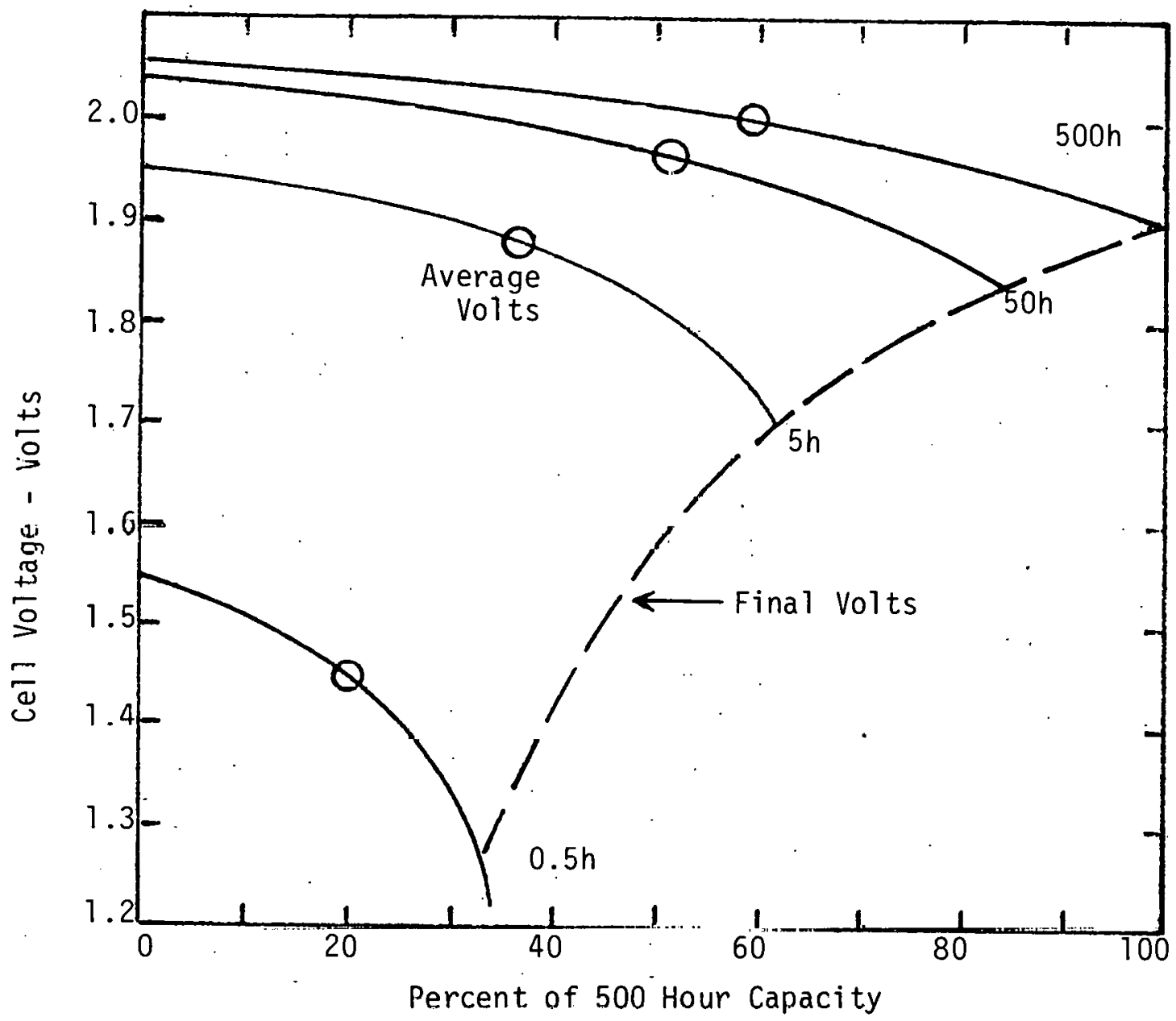

Figure 3-4 - Effect of Discharge Rate on Output at $25^{\circ} \mathrm{C}$

Each cell type, size and design will vary from Figure 3-4 depending upon the cell design parameters such as the number and thickness of the plates, active material density, volume and specific gravity of the electrolyte, and the plate grid and separator system designs.

Useful capacity from a cell is normally defined in terms of discharge hours or ampere-hours to the "knee of the discharge curve" or final voltage. Beyond this point, little capacity is available. As shown in Figure 3-4, the knee does vary with the discharge rate and 
represents the low voltage limit for the various rates. Energy output for each rate is the integral of cell power output (volts $x$ amperes) between discharge time zero and the time corresponding to the knee of the discharge curve, or final voltage. Average discharge voltages can be calculated by dividing the energy output in watt-hours by the corresponding capacity in ampere-hours. As an approximation the average voltage is the voltage at 0.6 times the discharge time to the final voltage.

Discharges may be terminated at some voltage higher than the knee of the curve. This voltage is called the discharge end voltage. It may be dictated by the test equipment, photovoltaic system components, or by an arbitrary choice. This end vol tage may be a constant independent of rate of discharge.

When the end voltage is higher than the final voltage, the cell size becomes larger, and the capacity not used becomes a reserve capacity which can extend cycle $11 f$ e.

In designing a battery for a particular photovol taic system, the number of battery cells needed in series can be determined by dividing the lowest specified system voltage by the final voltage of the cell selected when discharged at the required system rate for that cell. 
This minimum number of cells in series assures the battery discharge voltage will be at or above the specified minimum voltage in the system vol tage window.

Figure 3-5 is one method of displaying cell performance characteristics. The product of a particular current in amperes and the corresponding discharge time in hours read from this plot gives the rated or experimental mean capacity at any rate covered by the curve. Times to other end voltages are often shown as a family of similar curves.

The corresponding initial, average and final voltages are plotted for each discharge time. The system designer can obtain from this single figure a good estimate of the discharge time, the discharge capacity and the energy output (product of average voltage and capacity) at any discharge rate covered by the data. Table 3-1 summarizes a typical set of characteristics calculated from the data of Figure 3-5.

\section{TABLE $3-1$}

Cell Discharge Characteristics

\begin{tabular}{|c|c|c|c|c|c|c|}
\hline \multicolumn{2}{|c|}{ Discharge } & \multirow{2}{*}{$\begin{array}{l}\text { Discharge } \\
\text { Caparityy }\end{array}$} & \multicolumn{3}{|c|}{ Cell Voltage-Volts } & \multirow{2}{*}{$\begin{array}{l}\text { Energy } \\
\text { Output }\end{array}$} \\
\hline Time & Current & & Initial & Averaye & Final & \\
\hline$\underline{h}$ & A & Ah & $\underline{v}$ & $\underline{v}$ & $\underline{v}$ & Wh \\
\hline 100 & 20 & 2000 & 2.09 & 1.99 & 1.80 & 3980 \\
\hline 50 & 38 & 1900 & 2.08 & 1.97 & 1.78 & 3740 \\
\hline 10 & 160 & 1600 & 2.05 & 1.95 & 1.75 & 3120 \\
\hline 5 & 290 & 1450 & 1.98 & 1.92 & 1.70 & 2780 \\
\hline 1 & 1000 & 1000 & 1.77 & 1.60 & 1.48 & 1600 \\
\hline
\end{tabular}




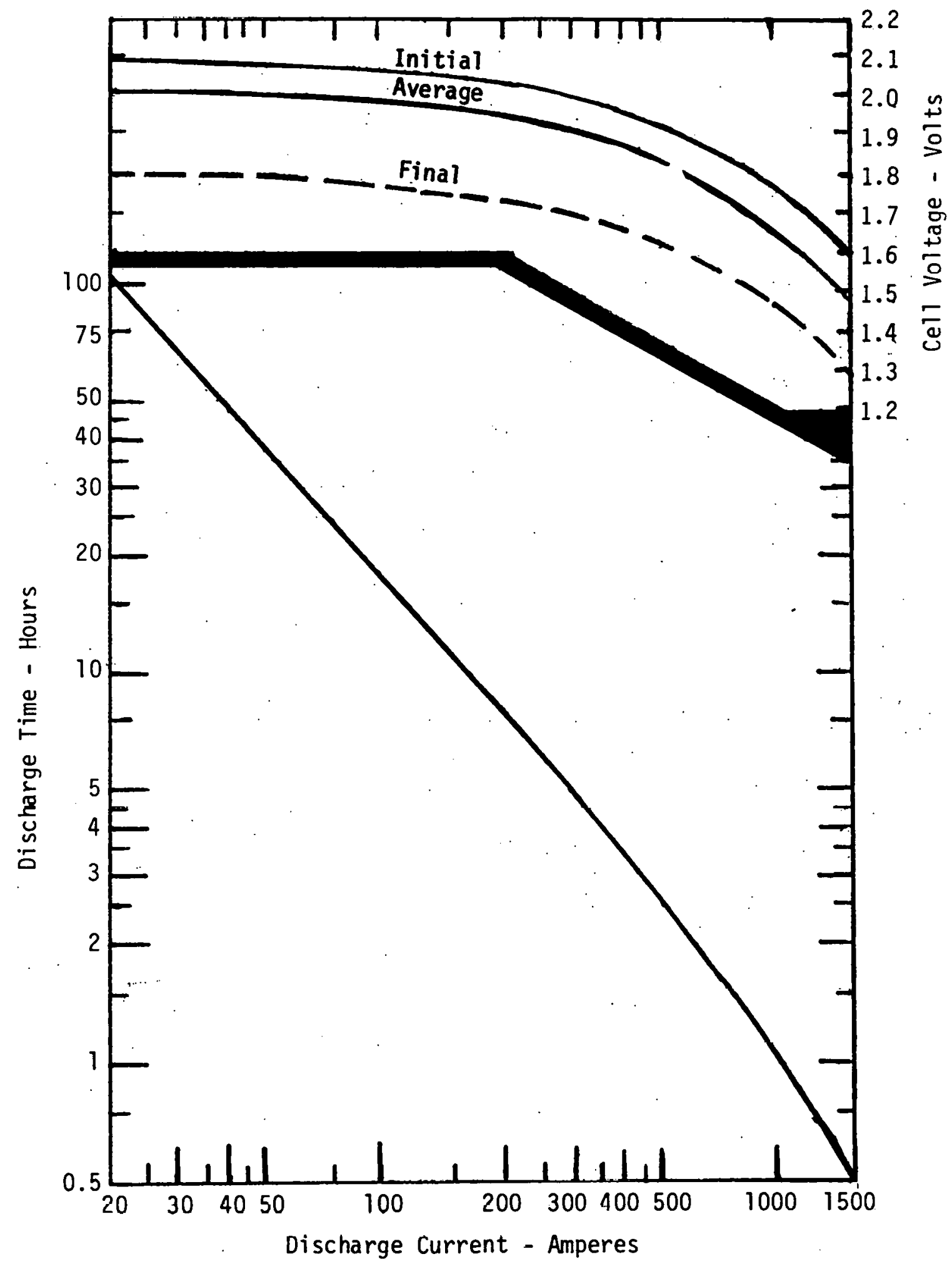

Figure 3-5 - Cell Discharge Characteristics 


\section{EFFECT OF SPECIFIC GRAVITY OF ELECTROLYTE AND OPERATING TEMPERATURE}

Another design consideration is the specific gravity of the electrolyte. Discharge capacity in any single cycle increases with an increase in specific gravity. The amount of increase will depend upon the discharge rate, the active material density and the ratio of actíve material to acid electrolyte.

When specific gravity is increased, charge standlife and cycle life will be decreased. Estimates of this loss can be made by the battery manufacturer for the particular battery under consideration.

The specific gravity increases during recharge and decreases during discharge. At low operating temperatures, the specific gravity can become so low that i.ts freezing temperature is reached terminating the discharge prematurely and interfering with the subsequent charge. Freezing points are shown in Table 3-2 for various concentrations of acid electrolyte.

TABLE 3-2

Freezing Points of Sulfuric Acid Electrolyte Specific Gravity $25^{\circ} \mathrm{C} / 25^{\circ} \mathrm{C}$ at freezing temperature

\section{Freezing Point}

${ }^{\circ} \mathrm{C} \quad{ }^{\circ} \mathrm{F}$

$\begin{array}{rrrr}1.000 & 1.003 & 0 & 32 \\ 1.050 & 1.060 & -3 & 26 \\ 1.100 & 1.115 & -8 & 18 \\ 1.150 & 1.175 & -15 & 5 \\ 1.200 & 1.235 & -27 & -17 \\ 1.250 & 1.305 & -52 & -61 \\ 1.300 & 1.365 & -70 & -95 \\ 1.350 & 1.405 & -49 & -56\end{array}$


Before selecting cell capacity and the specific gravity of acid in the cell, the photovoltaic system designer must consider the effects of environment temperature on cell operating temperature. In some cases the low voltage limit at the end of the deepest discharge may be established just above that voltage corresponding to an end of discharge specific gravity that could freeze.

Figure 3-6 shows the effect of operating temperature on discharge capacity for three electrolyte gravities in a lead-calcium battery selected for a solar photovoltaic system. At the 1, 8 and 500 hour rates of discharge only the highest gravity acid can be used below $-18^{\circ} \mathrm{C}$ $\left(0^{\circ} \mathrm{F}\right)$ wi thout danger of freezing.

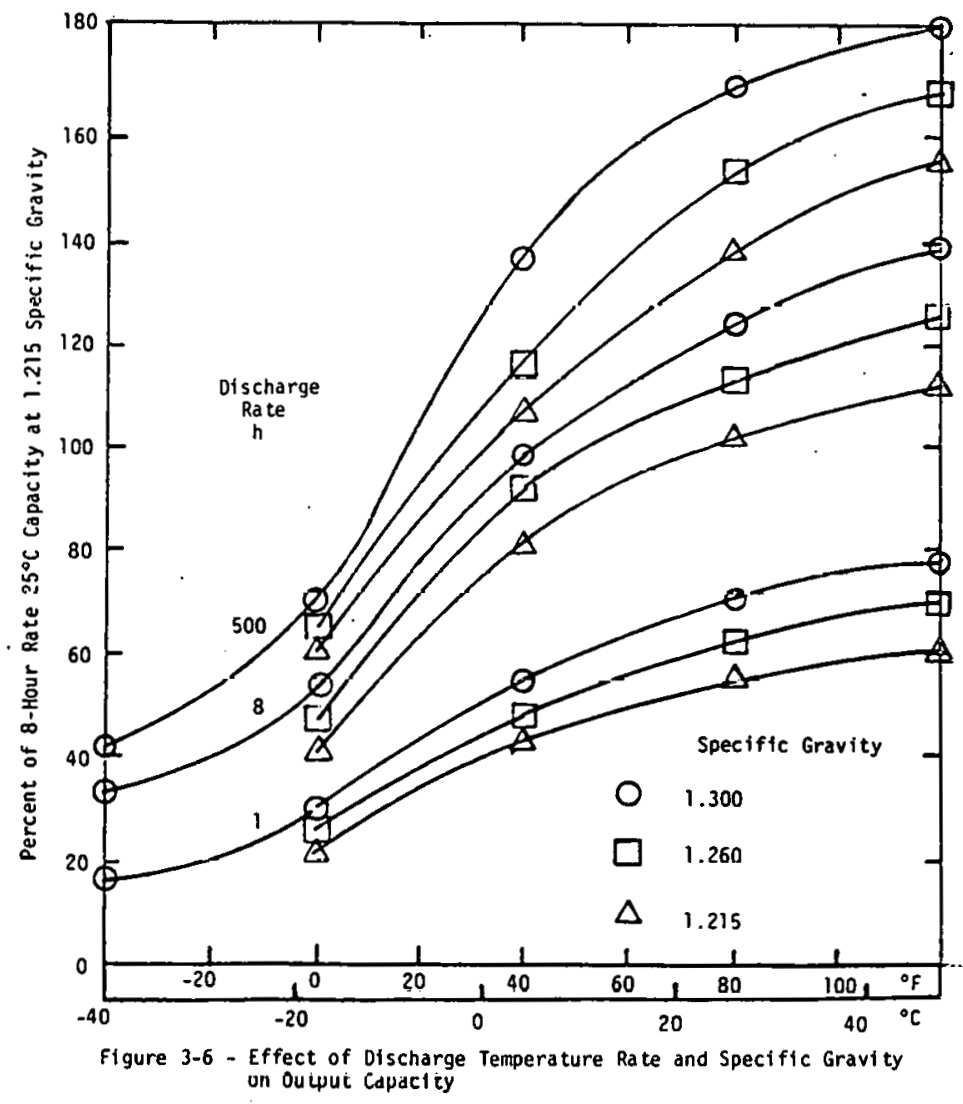




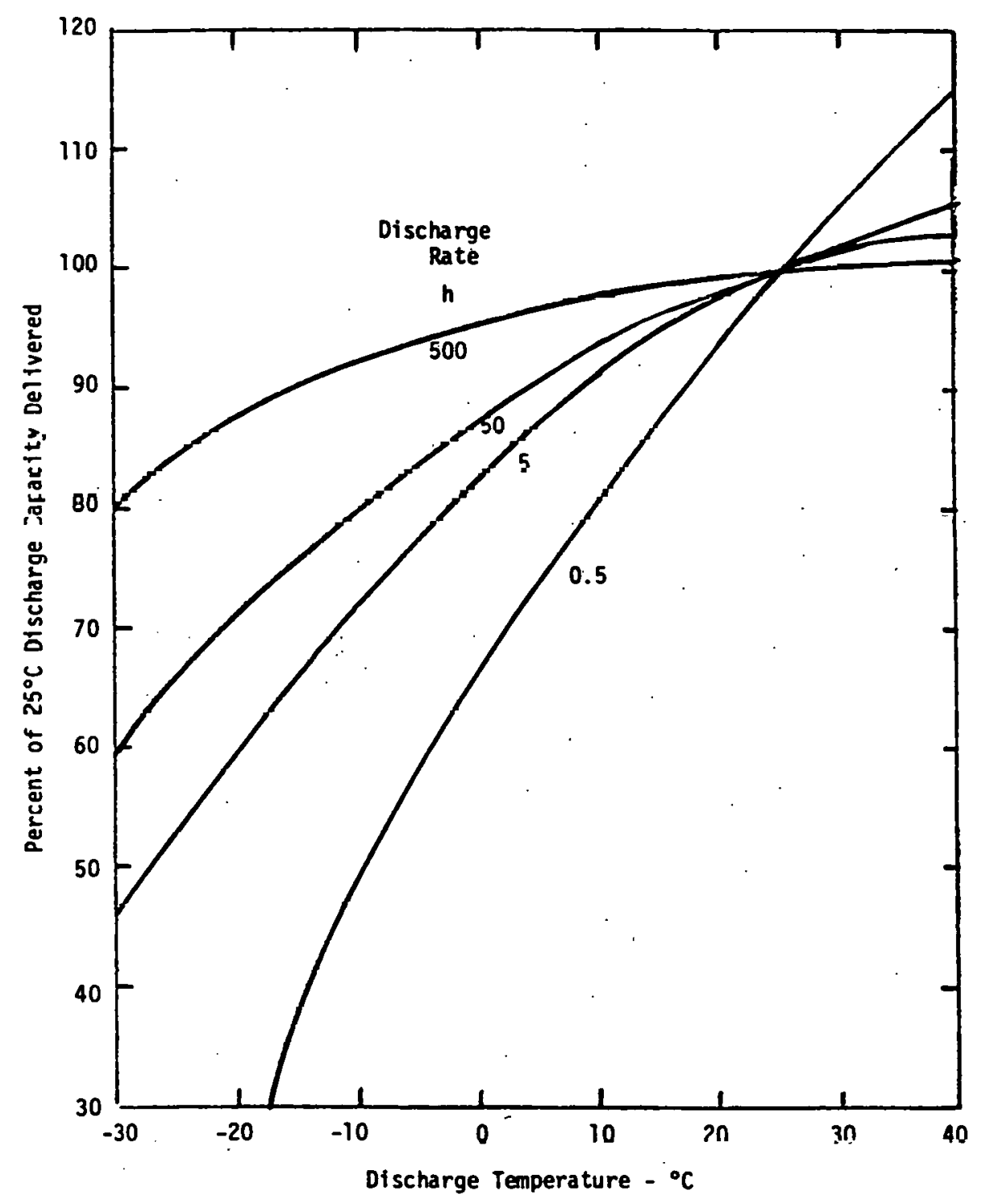

Figure 3-7 - Effect of Discharge Rate and Temperature on $25^{\circ} \mathrm{C}$ Discharge Capacity

For any particular specific gravity, the interaction of cell electrolyte temperature and discharge rate on output capacity is showri in Figure 3-7. The loss in capacity is particularly severe at high current rates of discharge and low temperature. At high temperatures, the gain in capacity is highest at the highest current rates of discharge. 
METHODS OF CHARGING LEAD-ACID BATTERIES

Proper recharging between discharges in an application duty cycle and proper maintenance charging are important keys to obtaining optimum life from any lead-acid battery under any condition.

Some of the rules for proper charging are given below and apply to all types of lead-acid batteries:

(1) The charge current at the start of recharge can be any value that does not produce an average cell voltage in the battery string greater than the gassing voltage.

(2) During the recharge and until 100 percent of the previous discharge capacity has been returned, the ampere rate should be controlled to maintain the gassing voltage, or lower, but as close to the gassing voltage as possible to minimize charge time.

(3) When 100 percent of the discharged capacity has been returned under the above voltage control, the charge rate will have normally decayed to the charge "finishing" rate. Finish the charge at a constant current no higher than this rate, normally $5 A / 100$ Ah 5-hour rated capacity. 
To achieve these rules there are a number of practices for charging lead-acid batteries. These charging methods are commonly given the following names :

1. Constant current - one current rate

2. Constant current - multiple decreasing current steps

3. Cunstant potential

4. Modified constant potential with constant initial current

5. Modified constant potential with a constant finish rate

6. Modified constant potential with a constant start and finish rate

7. Taper charge (ferroresonant type chargers)

In normal industrial field application, the charging methods are numbers 4,6 and 7 . Number 4 charging is found in on-the-road vehicles, utility, telephone, and uninterruptible power system applications. The charge circuit has a current limit and this value is maintained until a predetermined voltage is reached. Then the voltage is maintained constant until the battery is called on to discharge. Decisions must be made regarding the current limit and the constant voltage value. This is influenced by the time interval when the battery is at the constant voltage and in a 100 percent state-of-charge. For this "float" type operation with the battery always on charge, a low charge current is desirable to minimize overcharge, grid corrosion associated with overcharge, water loss by electrolysis of the electrolyte, and maintenance 
to replace this water. To achieve a full recharge with a low constant potential requires the proper selection of the starting current and this selection should be made in consultation with the battery manufacturer.

Charging method number 6 is common for deep cycling batteries for fork lift trucks used in material handling. Each work shift requires a discharge at the 6-hour rate to a depth of 80 percent of the 6-hour rated capacity, and the recharge is normally completed in an 8-hour period. The charger is set for the constant potential of 2.39 volts per cell (the gassing voltage) and the starting current is 1 imited to 16-20 amperes per 100 Ah of the rated 6-hour ampere-hour capacity. This initial current" is maintained constant until the average cell voltage in the battery reaches 2.39 volts. The current decays at constant voltage to the finishing rate of 4.5-5 A per 100 Ah which is then maintained to the end of charge. Total charge time is controlled by a timer. The time of charge is selected to assure a recharge input capacity of a predetermined percent of the previous output - normally 110 to 120 percent, or 10-20 percent overcharge. The 8-hour charging time can be reduced by increasing the initial current limit rate.

Charging method number 7 is a modification of method 6 to reduce equipment cost. The initial rate is limited, but the taper of voltage and current is such that the 2.39 volts per cell at $25^{\circ} \mathrm{C}$ is exceeded 
prior to the 100 percent return of the discharge ampere hours. This method does result in gassing at the critical point of recharge, and cell temperature is increased. The degree of gassing and temperature rise is a variable depending upon the charger design, and battery life can be degraded from excessive battery temperature and overcharge gassing.

End of charge is often controlled by a fixed voltage rather than a fixed current. Therefore, when a new battery has a high counter EMF, this final charge rate is low, and the battery often does not receive sufficient charge within the time period allotted to maintain the optimum charged state. During the latter part of life when the counter EMF is low, the charging rate is higher than the normal finishing rate, so the battery receives excessive charge which degrades life. Thus the taper charger does degrade battery life but usually has less controls, and parts and is therefore a less expensive circuit.

For photovoltaic battery systems designed for optimum life, charging control and regulation circuits should produce a pattern of voltage and. current equivalent to the best industrial circults. Modffled constant potential charging methods 4 and 6 are preferred. Optimum control to maximize life and energy output from the battery is best achieved when the depth of discharge and the time for recharge is predetermined and repetitious, a condition not always possible in solar PV applications. 
MAXIMUM BATTERY SUBSYSTEM VOLTAGE

Selection of the battery voltage at top-of-charge and the number of cells in a series string is critical to successful operation and maximum life.

The photovoltaic system has a voltage window, a voltage range from the lowest to the highest limits acceptable to meet operating requirements. The number of cells in series in the battery subsystem times the average cell discharge end voltage must be greater than the lower voltage window limit. Where this number of cells in series is used to set the upper. voltage limit in the window, the calculation may show the upper voltage limit is not sufficiently high to charge the battery in the allotted time. A compromise must then be made.

A key rule is that the cell gassing voltage should not be exceeded except during the finishing step of charge. The gassing voltage is the voltage at which the predominant reaction consuming charge current is electrolysis of water in the electrolyte with evolution of oxygen at the positive plates and hydrogen at the negative plates. Gassing voltage decreases with increasing electrolyte temperature. See Table 3-3. Note: Electrolyte temperature is not the same as ambient room temperature until after an extended exposure of the battery to ambient conditions. 
TABLE 3-3

Correction Factors for Cell Gassing Voltage

\begin{tabular}{|c|c|c|}
\hline $\begin{array}{l}\text { Electrolyte } \\
\text { Temperature } \\
\text { oC of }\end{array}$ & $\begin{array}{c}\text { Cell } \\
\text { Gassing Vol tage } \\
\text { Volts }\end{array}$ & $\begin{array}{c}\text { Correction } \\
\text { Factor } \\
\text { Volts }\end{array}$ \\
\hline $\begin{array}{rr}50 & 122 \\
40 & 104 \\
30 & 86 \\
25 & 77 \\
20 & 68 \\
10 & 50 \\
0 & 32 \\
-10 & 14 \\
-20 & -4\end{array}$ & $\begin{array}{l}2.300 \\
2.330 \\
2.365 \\
2.390 \\
2.415 \\
2.470 \\
2.540 \\
2.650 \\
2.970\end{array}$ & $\begin{array}{r}-.090 \\
=.060 \\
-.025 \\
0 \\
+.025 \\
+.080 \\
+.150 \\
+.260 \\
+.508\end{array}$ \\
\hline
\end{tabular}

When designing the system for $25^{\circ} \mathrm{C}$ operation, the constant charge potential for the battery subsystem would be 2.39 volts times the number of cells in series. If system temperature exceeds $25^{\circ} \mathrm{C}$, the cells will gas and life of the subsystem will be decreased. If system temperature falls below $25^{\circ} \mathrm{C}$, charge acceptance will he decroased requiring a longer charge time to sustain the same state-of-charge.

Charging controls and regulator circuits must therefore include a temperature compensation feature to correct the constant charge voltage to the $25^{\circ} \mathrm{C}$ equivalent using the correction factors shown in Table $3-3$. Wi thout the temperature compensating circuit, a battery charge circuit adjusted to 2.39 volts per cell at $25^{\circ} \mathrm{C}$ ambient would charge the battery at $0^{\circ} \mathrm{C}$ at an actual voltage of 2.24 volts per cell. To compensate +0.150 volts per cell must be added to the charge vol tage as required by Table 3-3 
to achieve charge conditions equivalent to those at $25^{\circ} \mathrm{C}$. Otherwise the lower actual voltage would substantially increase charge time or would prevent the desired state-of-charge from ever being reached.

For most lead-acid battery subsystems, charged by voltage regulator circuits properly compensated for changes in operating temperature, the number of cells in series is obtained by dividing the maximum system charge voltage by the maximum charge voltage in volts per cell specified by the cell manufacturer. This maximum voltage is normally $2.60-2.65$ volts per cell and is the maximum voltage the cell is allowed to reach during the finishing step of charge. Table 3-4 gives an example of the calculation of the number of cells in series for a system voltage window and the voltage control during each charge step.

TABLE 3-4

Battery Subsystem Voltage vs. System Window $(200-300$ Volts $)$

\begin{tabular}{lcc}
$\begin{array}{l}\text { System } \\
\text { Design Parameter }\end{array}$ & Unit & Value \\
\hline Array Voltage Regulator Upper Limit & Volts & $300(1)$ \\
Cell Charge Voltage Limit & Volts Per Cell & 2.60 \\
$\begin{array}{l}\text { Number of Cells in Series String } \\
\text { Cell Final Discharge Voltage Limit }\end{array}$ & Each & 115 \\
$\quad$ (5-h Discharge Rate) & & 1.70 \\
Baitery Cut-out Setting & Volts & 200 \\
NOTE: (1) Temperature compensated in accord with Table 3-3 &
\end{tabular}


This charging method has three steps and a dual voltage control:

Step

1

2

3
Mode

Initial Constant Current

Current Tapers to Finishing Rate

Finishing Rate Constant
Voltage Control

2.39 Volts Per Cell

same

2.60 Volts Per Cell

\section{Current}

STRATIFICATION OF ELECTROLYTE IN CELLS

Stratification of acid electrolyte into levels or varying specific. gravity can limit charge acceptance, discharge output and life unless understood and controlled during the charge process.

During a recharge, the oxidation of $\mathrm{PbSO}_{4}$ to $\mathrm{PbO}_{2}$ at the positive plates and the reduction of $\mathrm{PbSO}_{4}$ to $\mathrm{Pb}$ at the negative plates forms sulfuric acid of higher concentration in the pores of the positive plates. This higher density acid.settles to the bottom of the cell giving higher specific gravity acid near the bottom of the plates and lower specific gravity acid near the top of the plates. This stratification accumulates during non-gassing periods of charge. During gassing periods of charge, partial stirring is accomplished by gas bubbles formed at and rising along the surfaces of the plates and in the separator system.

During discharge, acid in the pores of the positives and near their surface is diluted; however, concentration gradients set up by longer 
charge periods are seldom compensated entirely during shorter discharge periods.

Diffusion processes to eliminate these concentration gradients are very slow, so stratification during repetitious cycling can become progressively greater. Two methods for stratification control are by deliberate gassing of the plates during overcharge at the finishing rate or by stirring of cell electrolyte by air-lift pumps. The degree of success in eliminating stratification is a function of cell design, the design of the air-lift pump accessory system, and cell operating procedures.

Overcharge at the finishing rate may be increased to obtain the required electrolyte circulation after deep discharges. Very large, tall cells may require air-lift pumps which use an outside air pressure source to operate one or more air-lift pumps to circulate dense acid from the bottom to the top of the cell.

Correct electrolyte circulation can increase the utilization of positive and negative active material, increase capacity and energy output. and increase life. In most solar photovol taic systems which now require smaller cells, adequate circulation can be achieved by judicious control of the percent of overcharge and the relative times of charge and discharge. The battery engineer should participate in the system design and in setting up the operating procedures. 


\section{SELECTION OF CHARGE CURRENTS}

Selection of charge currents for the initial high rate and final low rate charge periods is complicated by the following restraints:

- Completing the charge in the required time

- Remaining within the voltage limits

- Charging at rates which restore discharge capacity without excessive temperature rise

Initial charge currents range up to $20-25 \mathrm{~A}$ per 100 Ah rated $5-\mathrm{h}$ capacity. Final or finishing constant charge current ranges from 4-5 A per 100 Ah rated $5-h$ capacity. During the last hours of charge at the finishing rate cell charge voltage increases with increasing finishing rate. At the normal finishing rate of $5 \mathrm{~A}$ per $100 \mathrm{Ah}$ end-of-charge voltage for newly produced cells can vary from 2.65 to 2.90 volts at $25^{\circ} \mathrm{C}$ depending upon the cell design and composition of the grids and the active materials. As battery life progresses the end-of-charge voltage for pure lead and lead-calcium cells remains essentially constant. For lead-antimony cells the end-of-charge voltage decays progressively during their cycle life to values as low as 2.45 to 2.50 volts after 2000 deep cycles.

This characteristic explains a common praclice uf designing the lead-antimony battery subsystem around the average end-of-charge voltage of 2.60 volts. Table $3-5$ shows the results of this practice during battery life. 
TABLE 3-5

Effect of Age of Lead-Antimony Battery on End-of-Charge Current and Vortage

Relative

Age

\%.

New

25

75

100

(End-of-Life)

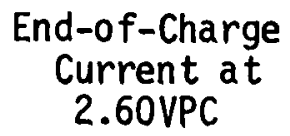

A/100 Ah

0.50 to 0.75

1.50 to 2.00

4.5 to 5.50

13.5 to 16.5
End-of-Charge

Voltage at

$5 \mathrm{~A} / 100 \mathrm{Ah}$

Finishing Rate

Volts
Remarks

2.90

2.75

2.60

2.45
Low current prolongs time of charge

Desirable state

Extreme gassing and higher cell temperature shortens cell life.

The conditions of Table $3-5$ are the result of high rates of selfdischarge from a high antimony alloy in the positive grid and in the negative grid. As cell design changes decrease this local action selfdischarge loss, the change of end-of-charge voltage with battery life will decrease.

Table 3-6 illustrates the effects of depth of discharge, initiat charge rate and the finishing rate on charge time for the case of a modified constant potential charge with an initial constant charge rate. of 16 or $20 \mathrm{~A}$ per $100 \mathrm{Ah}$ and a constant finishing rate of 2.5 or $5 \mathrm{~A}$ per 100 Ah of $5-h$ rated capacity. 
TABLE 3-6

Effect of Discharge Depth, Initial Charge Rate at 2.39 VPC and Finishing Rate on Charge Time

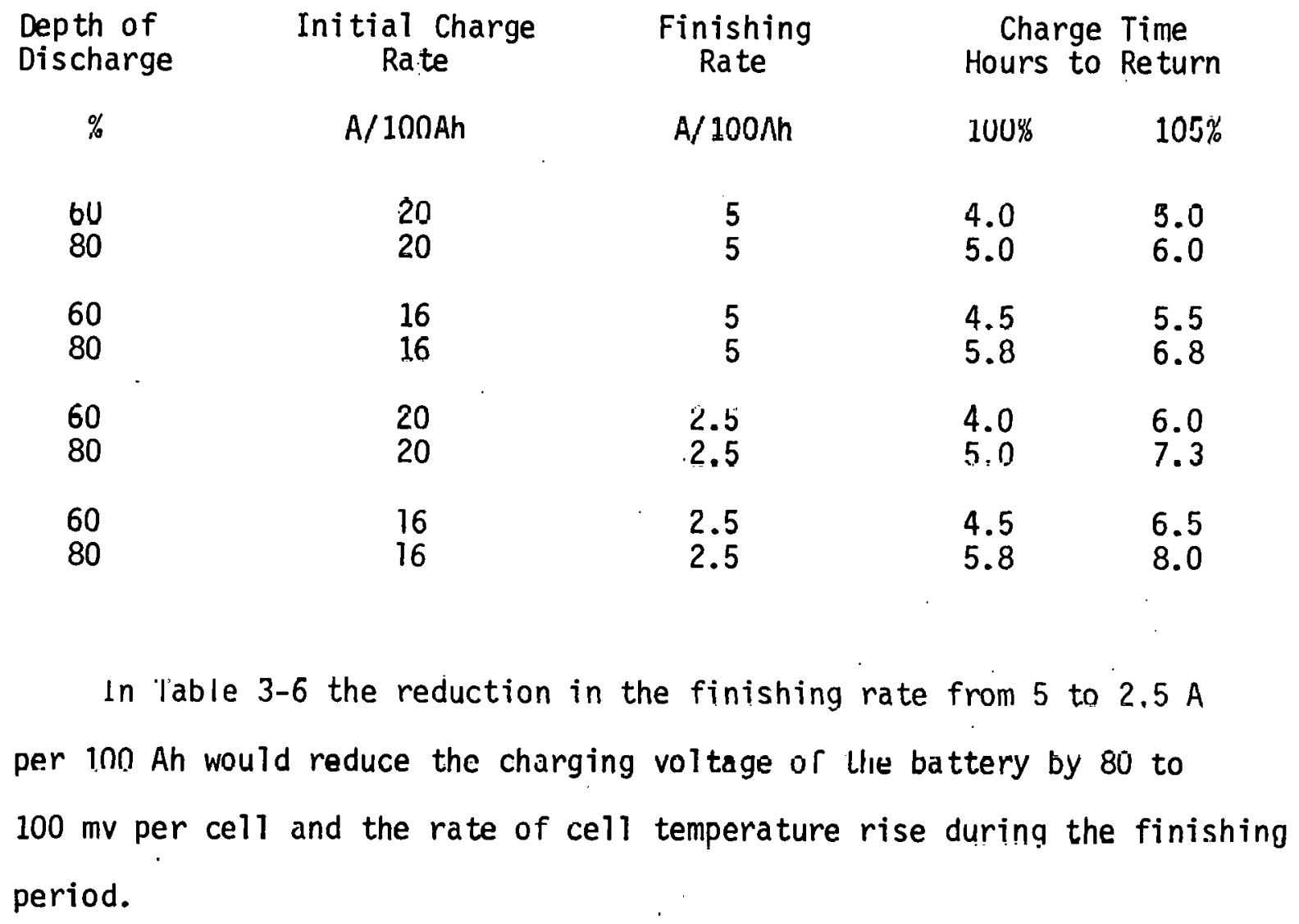

The effect or inltlal charge rate and charging voltage on charge time is shown in Table 3-7 for the case of a modified constant potential charge where the end-of-charge current is governed by the preset potential. 
TABLE 3-7

Effect of Initial Charge Current and Constant Potential on Charge Time for 60 and 80\% Depth of Discharge

\begin{tabular}{ccccc}
$\begin{array}{c}\text { Depth of } \\
\text { Discharge }\end{array}$ & $\begin{array}{c}\text { Initial Charge } \\
\text { Rate }\end{array}$ & $\begin{array}{c}\text { Constant } \\
\text { Potential }\end{array}$ & \multicolumn{2}{c}{$\begin{array}{c}\text { Charge Time } \\
\text { Hours to Return }\end{array}$} \\
$\%$ & A/100Ah & Vol ts at $25^{\circ} \mathrm{C}$ & $100 \%$ & $105 \%$ \\
60 & 20 & 2.39 & 4.0 & 6.3 \\
80 & 20 & 2.39 & 5.0 & 7.8 \\
60 & 16 & 2.39 & 4.5 & 6.8 \\
80 & 16 & 2.39 & 5.8 & 8.5 \\
60 & 20 & 2.25 & 8.0 & 14.0 \\
80 & 20 & 2.25 & 10.0 & 18.0 \\
60 & 16 & 2.25 & 8.5 & 14.8 \\
80 & 16 & 2.25 & 10.8 & 19.0
\end{tabular}

During repetitious cycling at $25^{\circ} \mathrm{C}$ and at depths of discharge as deep as $60-80 \%$, a capacity return of $105-110 \%$ is normally required to maintain a given state-of-charge. Higher operating temperatures will require higher overcharge or a weekly equalization charge, or both.

Summarizing, to decrease charge time while maintaining a consistent state-of-charge, the following procedures should be used:

- Increase the initial charge current up to a maximum value of $25 \mathrm{~A} / 100$ Ah rated $5=\mathrm{h}$ cell capacity.

- Use the highest setting of constant potential during the initial charge current period without exceeding the temperature compensated cell gassing voltage. 
- Use three step charge with final finishing current controlled at $5 \mathrm{~A} / 100$ Ah $5-\mathrm{h}$ rated cell capacity.

- Allow time for a prolonged equalization charge at some regular interval of accumulated discharge capacity. 


\section{EFFECT OF CELL DESIGN ON BATTERY LIFE}

Battery life in years and cycles will depend upon the design features of cell components:

- Weight of lead and alloy composition in plate grids

- The dispersement of this lead in the grid structure

- The weight, density and composition of the active material in the positive and negative plates

- Electrolyte specific gravity

- Absence of impurities that could give interplate metallic shorts or excessive local action gassing of the plates

- Separator system and protection against shorting through accumulation of sediment

These design variables control the life and cell performance characteristics. For example, automobile starter-light-ignition (SLI) batteries give excellent initial cycle service but last for only 150-200 deep cycles. Newer on-the-road electric vehicle batteries are designed for somewhat longer cycle service (400-700 cycles). Industrial motive power batteries are designed with cycle life as a major design requirement and can deliver 1500 to 2000 cycles. Thick plate charge retaining batteries have excellent charged stand: and low rate charge and discharge characteristics, but these cannot deliver or accept high power.

Thus, the cell design must be properly selected to meet the particular solar PV application. Battery manufacturers' application engineers can help make the cell design decision a wise one from the point of view of life as well as duty cycle performance. 


\section{EFFECT OF OPERATING PARAMETERS ON BATTERY LIFE}

Discharge capacity, power and energy requirements of the battery subsystem can be delivered by a variety of lead-acid batteries during early charge-discharge cycles of the battery's life. However, the subsystem cost per cycle can be decreased substantially in most applications by selecting a battery design with good charge stand capability, with a long operating life and with a capability for many repetitious shinrgedischarge cycles.

In some cases the battery design features which increase life tend to decrease the initial capacity, power and energy output, but the rate of decay of capacity with the number of cycles delivered can be significantly less. The photovoltaic system designer should therefore make certain that battery design features match the system operating and life requirements.

Operating parameters which influence battery life are depth of discharge, number of cycles required per year, and charging control.

- Increasing depth of discharge decreases cycle life

- Increasing the number of cycles performed per year decreases the wet life

- Excessive overcharging leads to increased positive grid corrosion, active material shedding and shorter wet life. 
Proper charging operations with good equipment maintains the desired state-of-charge with a minimum of overcharge and leads to optimum battery life.

Figure $3-8$ is an example of the effect of discharge cycle depth and the number of cycles per year on battery life for one type of commercially available industrial battery.

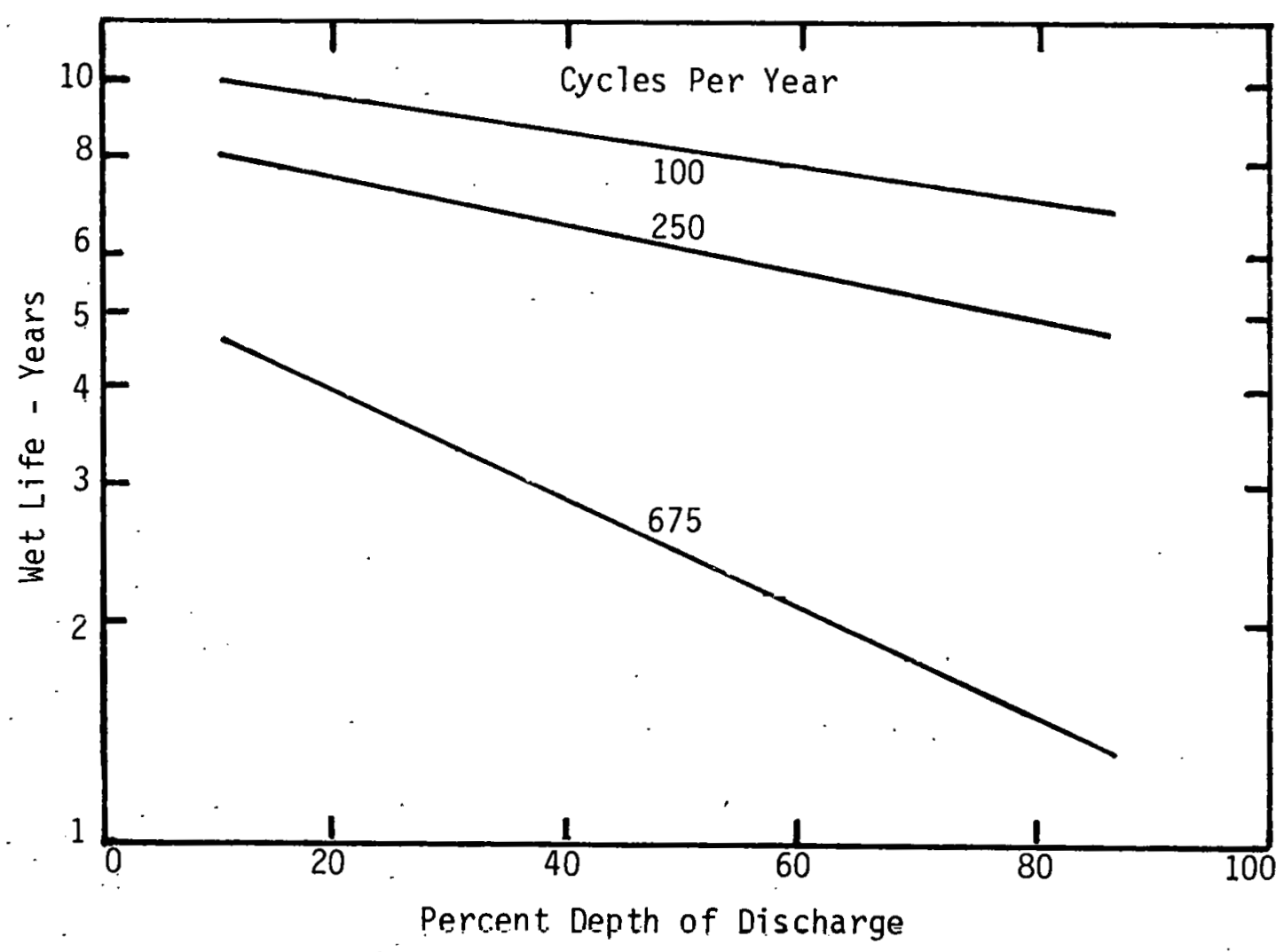

Figure 3-8 Effect of Depth of Discharge and Number of Cycles per Year on Wet Life, $25^{\circ} \mathrm{C}$. 
Figure 3-9 is the more commonly published curve showing the relationship between the number of cycles to failure versus the discharge cycle depth. In most photovoltaic system operations no more than two cycles per day can be expected. One cycle per day is most common; however, assuming one cycle per day for a curve similar to Figure 3-9 can lead to false and high estimates of battery operating life in years. Battery life must therefore be verified by actual test.

\section{ENVIRONMENTAL EFFECTS ON BATTERY LIFE}

Operating temperature of the battery has a profound effect on operating characteristics and the life of a lead-acid battery.

Discharge capacity is increased at higher temperatures and decreased at lower temperatures. At higher temperatures, the fraction of theoretical capacity delivered during discharge increases. This increase in capacity per unit weight of active material decreases cycle life because more charge input and more discharge output is required for each cycle.

High temperature also increases local action or self-discharge. The rate of chemical local action processes would be expected to double for each $10^{\circ} \mathrm{C}$ increase in operating temperature. One measure of local action is the current at a predetermined float voltage. See Figure 3-10. 


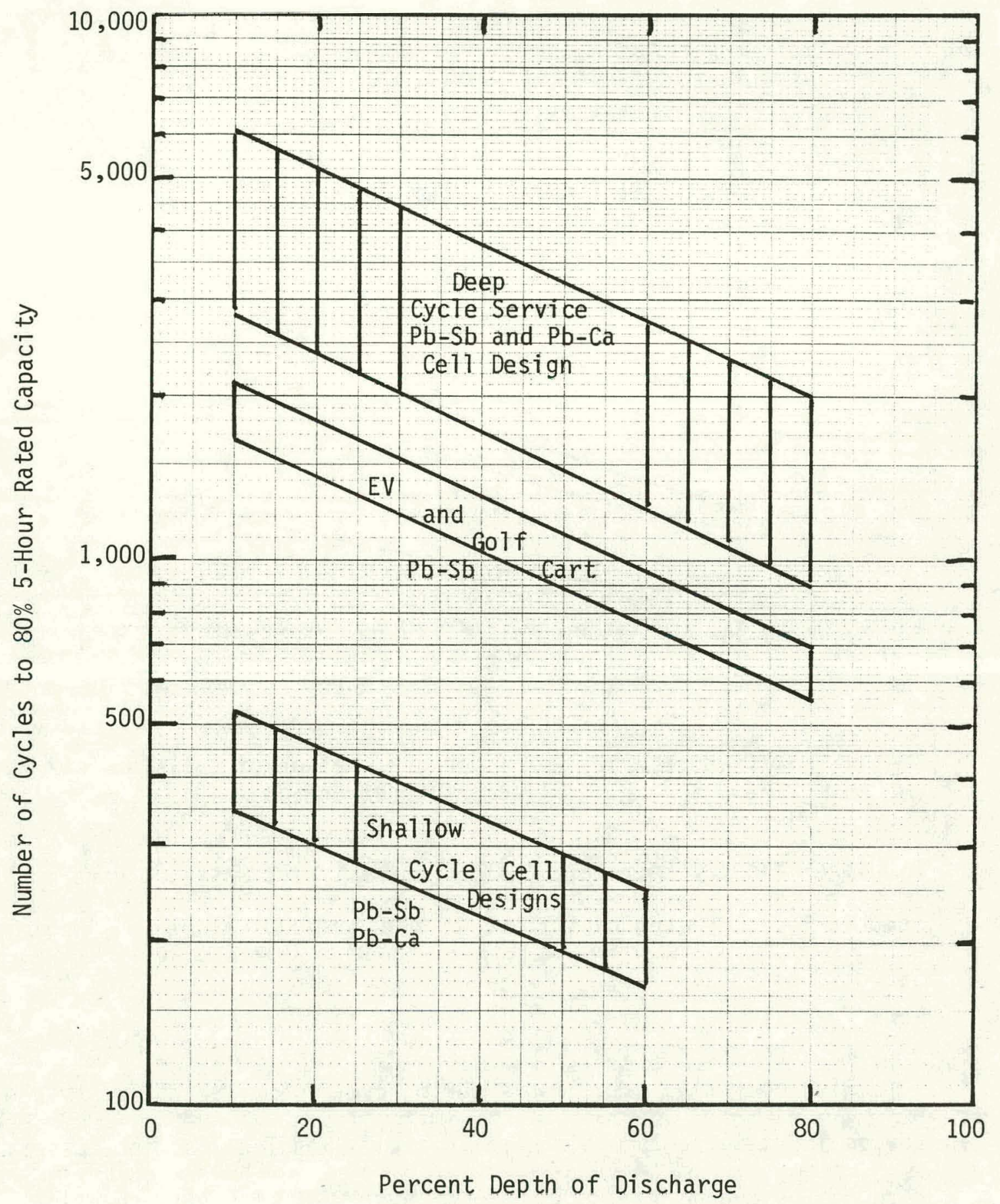

Figure 3-9 Effect of Cell Design and Discharge Depth on Estimated Cycle Life of Lead-Acid Cells at $25^{\circ} \mathrm{C}$ 


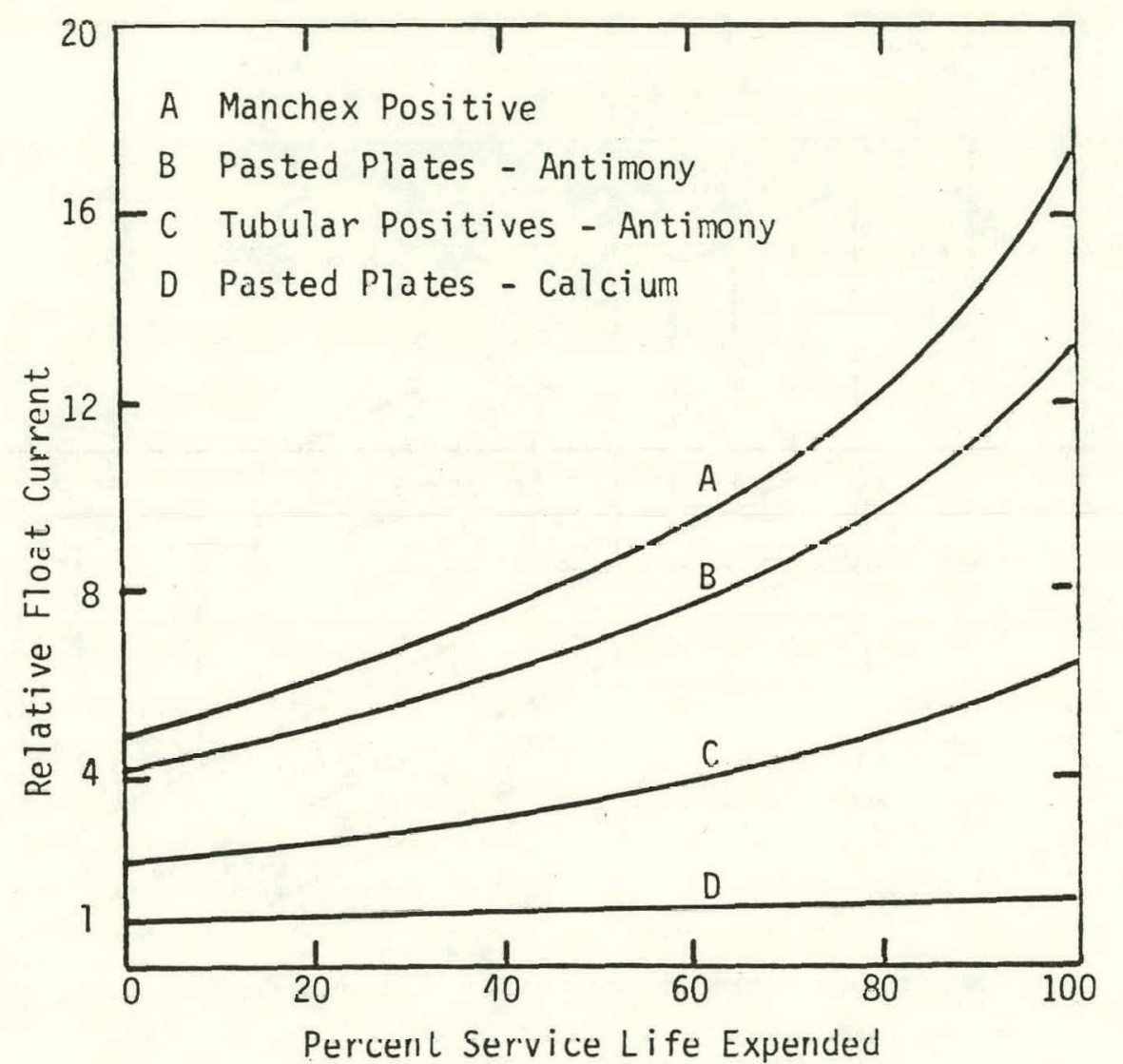

Figure 3-10 Relative Local Action of Cells of Different Construction

At higher float temperatures, float currents increase and give much reduced life. Eleven days float at $75^{\circ} \mathrm{C}$ are equivalent in life to 365 days at $25^{\circ} \mathrm{C}$.

High operating temperature during cycle service requires higher charge input to restore discharge capacity and local action losses. More of the charge input is consumed by the electrolysis reaction because of the reduction in the gassing voltage at the higher temperature. Where 10 percent overcharge per cycle maintains state-of-charge at $25-35^{\circ} \mathrm{C}$, $35-40 \%$ overcharge may be required to maintain state-of-charge at the higher $60-70^{\circ} \mathrm{C}$ operating temperature. 
One attempt to relate operating temperature of cycling cells to cycle life limited by positive grid corrosion has shown cycle life at $49^{\circ} \mathrm{C}$ is $40 \%$ of cycle life at $25^{\circ} \mathrm{C} .{ }^{(3-5)} \mathrm{E}$. A. Wagner in unpublished data gives a derating factor of 0.7 to be applied to $25^{\circ} \mathrm{C}$ cycle 1 ife for each $16^{\circ} \mathrm{F}\left(8.9^{\circ} \mathrm{C}\right)$ rise in cell operating temperature.

Shelf stand loss from local action is not a major concern in daily cycle service at normal temperatures. At 80 percent depth of discharge in a daily cycle, the stand loss of capacity in a leadantimony battery subsystem may approach 0.5 percent per day, which is compensated by the daily recharge.

Figure 3-11 shows the typical effect of charged stand temperature on capacity loss rates for charge retaining batteries designed for this type of service.

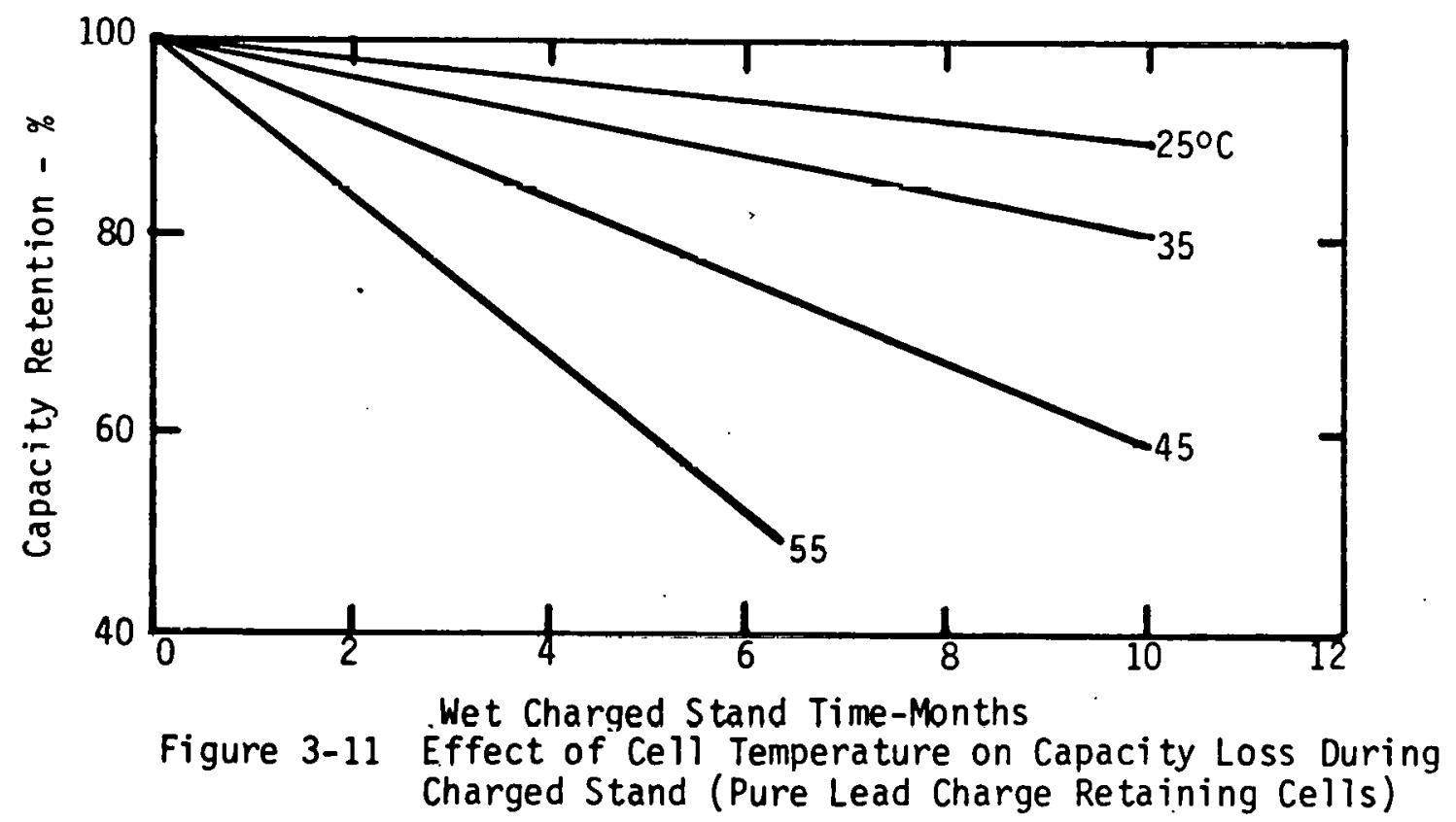


When system power drains are very low for 30 days or longer without recharge, local action can add to capacity drain significantly. The battery must then be oversized to compensate for this loss. The battery type will determine the amount of excess capacity required.

For a high antimony lead-acid battery, a 130-150 Ah capacity may be required to deliver 100 Ah over a 30 day period to the load whereas for a lead-calcium or pure lead battery, only 102-104 Ah would be needed. This trade off must be considered.

In general, therefore, solar photovoltaic systems must be designed to maintain nominal ambient temperatures on the battery subsystem by providing shade from direct sunlight and good air circulation over battery intercell and interrow connectors. Natural heat sinks such as the earth should be used whenever posstble for remote solar PV installations to minimize the range of battery temperature excursions. 


\section{MAINTENANCE OF LEAD-ACID BATTERIES}

Battery subsystems for photovoltaic installations in remote locations must require low maintenance. The cost of maintenance can be prohibitive for remote systems in isolated areas where service personnel can visit the installation no more than once or twice a year.

Attended systems may have trained personnel available to perform maintenance. Battery designs with greater wet and cycle life, but which may also require greater maintenance, may be selected for these applications. A key step to long life is to properly train service personnel using service and operating instructions provided by the battery and photovoltaic system manufacturers.

Maintenance will normally consist of equalization charges, watering of battery cells, checks on individual cell voltage and specific gravity, and cleaning the tops of cells of dust, dirt, acid spillage and spray.

\section{EQUALIZATION}

During cycling, a high voltage battery having many cells in a series string can become unbalanced with certain cells limiting charge and discharge. Limiting cells receive more overcharge than other cells in 
the string, have greater water consumption and thus require more maintenance. The equalization charge has the function of balancing cells in the string at the top-of-charge.

Equalization charge simply extends the normal recharge for 3-6 hours at the finishing rate of $5 \mathrm{~A}$ per $100 \mathrm{Ah} 5$-h rated capacity, allowing the battery voltage to rise uncontrolled. Equalization charge should be continued until cell voltages and specific gravities rise to a constant, acceptable value. See manufacturer's maintenance instructions for details. Frequency of equalization charge is normally a function of the accumulative discharge output and will be specified by the manufacturer for each battery design and application.

\section{WATERING CELLS}

During normal operation, water is lost from a battery as the result of evaporation and electrolys is into hydrogen and oxygen which escape into the atmosphere. Evaporation is a relatively small part of the loss except in very hot, dry climates. With a fully charged battery, electrolysis consumes water at a rate of $0.336 \mathrm{cc}$ per Ah overcharge. A 500 Ah cell overcharged 10 percent can thus lose $16.8 \mathrm{cc}$, or about $0.3 \%$ of $i$ ts water, each cycle. 
Since replacing water can be a major maintenance cost, water loss can be reduced by controlling the amount of overcharge and by using hydrogen and oxygen recombining devices in each cell where possible.

Addition of water is best accomplished after recharge and before an equalization charge. Add water to reach the high acid level line at top-of-charge. Gassing during charge will stir the water into the acid uniformly. Do not add water in very cold weather when it may freeze before mixing. Water added must be distilled water, demineralized water, or local water which has been approved for use in batteries.

Automatic watering devices now in development and reliability testing can reduce maintenance labor costs further. Overfilling must be avoided as the resultant overflow of acid electrolyte will cause tray corrosion, ground paths, and loss of cell capacity.

A final check of specific gravity should be made after water is added to assure correct acid concentration at the top-of-charge. A helpful approximation is the equation:

Specific Gravity $=$ Cell Open Circuit Voltage -0.845

which permits electrical monitoring of specific gravity on an occasional basis. 


\section{SAFETY PRECAUTIONS}

Precautions must be routinely practiced to prevent explosions from ignition of the flammable gas mixture of hydrogen and oxygen formed during overcharge of lead-acid cells. The maximum rate of formation is 0.418 liters of hydrogen and 0.209 liters of oxygen per Ah overcharge at standard temperature and pressure. The gas mixture is explosive when hydrogen in air exceeds 4 percent by volume. Standard practice is to set warning devices to alarm at 20-25 percent of this lower explosive limit (LEL). Low cost hydrogen detectors are available commercially for this purpose.

Wi th good air circulation around the battery, hydrogen accumulation is normally not a problem; however, if relatively large batteries are confined in small rooms, exhaust fans should be installed to vent the room constantly or be turned on automatically when hydrogen accumulation exceeds 20 percent LEL. Battery boxes should also be vented to the atmosphere. Sparks or flame can igni te these hydrogen atmospheres above the LEL. To prevent ignition, electrical sources of arcs, sparks, or flame must be mounted in explosion-proof metal boxes. Battery cells similarly can be equipped with flame arrestors in the vents to prevent oùtside sparks from igniting explosive gases inside the cell cases. It is good practice to refrain from smoking, using open flames, or creating sparks in the vicinity of a battery. 
Some types of batteries release small quantities of the toxic gases stibine and arsine. These batteries have positive plates which contain in the grid alloy small quantities of the metals antimony and arsenic to harden the grid and to reduce the rate of corrosion of the grid during cycling. These alloying agents also substantially increase the ability of the positive plate to cycle with good utilization of positive active material through a deep cycle life of 2000-3000 cycles. OSHA 1978 concentration limits for $\mathrm{SbH}_{3}$ and $\mathrm{AsH}_{3}$ are 0.1 PPM and 0.05 PPM respectively as the maximum allowable weighted average exposure for any 8-hour period. During continuous overcharge of such a battery, stibine $\left(\mathrm{SbH}_{3}\right)$ is released at an average rate of $0.05-0.15 \mathrm{mg}$ per 1000 Ah rated $5-\mathrm{h}$ capacity per ampere-hour of overcharge depending upon the overcharge rate and the alloy composition. The amount of arsine $\left(\mathrm{AsH}_{3}\right)$ released will be less than one-tenth the amount of stibine. If these gases are allowed to accumulate in the battery room, toxic conditions can be created.

Ventilation is therefore doubly important. All tests indicate ventilation designed to maintain hydrogen below 20 percent LEL will also maintain stibine and arsine well below their toxic limits.

The system designer should consult the battery manufacturer's application or sales engineer to review and approve the battery box or room design, its ventilation, and safety features to promote good safety practice. 
SAFETY RULES TO AVOID CHEMICAL BURNS AND SHOCK HAZARDS

Severe burns can be caused by the sulfuric acid contained in lead-acid batteries .

- Do not get acid in eyes, on skin or on clothing. In case of contact, flush immediately and thoroughly with clean water. Obtain medical attention when eyes are affected.

- Wear a fare shield. plastic or rubber aprül and gloves when handling acid. Avoid spilling acid.

- Bicarbonate of soda solution (one pound to a gallon of water) will neutralize any acid accidentially spilled. Apply the solution until bubbling stops, then rinse with clear water.

Batteries are electrically alive at all times!

- Keep the top of the battery clean and dry to prevent ground shorts and corrosion.

- Do not lay metallic ubjects on the battery; insulate all tonls used in working on the battery to prevent short circuits. Also remove all jewelry before working on the battery.

- When lifting batteries, use completely insulated lifting tools to avoid risk of short circuits between cell terminals by lifting chains ur huoks.

- Only personnel who have been trained in battery installation, charging and maintenance should be allowed to work on the battery subsystem. 


\section{REFERENCES:}

3-1 G. W. Vinal, Storage Batteries, Fourth Edition, John Wiley \& Sons, Inc., New York, 1965, p. 74.

3-2 IBID, p. 75

3-3 IBID, p. 77

3-4. H. Bode, Lead-Acid Batteries, John Wiley \& Sons, Inc., New York, N.Y. 1977, p. 346.

3-5 N.J. Maskalick, Proceedings of the American Power Conference Volume 41,1049 (1979).

3-6 E. A. Wagner, Private Communication, July 1978.

3-7 Bacharach Instrument Company, 2300 Leghorn Street, Mountain View, CA. 94043 
CHAPTER 4

NICKEL-CADMIUM BATTERIES

- Chemistry and Construction

- Discharge Characteristics of NiCd Cells

- Charging Characteristics

- Operating and Charged Stand Life

- Maintenance and Safety Precautions

- References

Work Performed for

The U.S. Department of Energy

Sandia National Laboratories

Albuquerque, New Mexico 87185

Under Contract No. 13-2202 


\section{CHAPTER 4 \\ NICKEL-CADMIUM BATTERIES}

Nickel-cadmium alkaline batteries have gained respect as a very reliable, long life electrochemical system from their performance in industrial starter and standby service and in the space program.

$(4-1)$ Space batteries were sintered plate type cells, hermetically sealed, requiring precision workmanship and very high quality control on the manufacturing line. Their chief disadvantage for use in terrestrial solar photovoltaic systems is their very high cost. Industrial nickelcadmium batteries with lower cost are commercially available for starter, standby and cycling service. These are normally pocket plate types which are vented to the atmosphere through resealable vents in each cell to relieve abnormally high internal pressures without spontaneous oxidation of their cadmium negative plates by atmospheric air. Industrial pocket plate cells are suitable for solar photovoltaic systems and can bc considered by the system designer.

\section{CHEMISTRY AND CONSTRUCTION}

Active materials in nickel-cadmium cells are nickel hydrate ( $\mathrm{NiOOH}$ ) in the charged positive plate and sponge cadmium ( $C d$ ) in the charged negative plate. The electrolyte is an aqueous potassium hydroxide ( $\mathrm{KOH}$ ) solution in concentration of 20-34 percent by weight pure $\mathrm{KOH}$. The basic electrochemical reaction is:

$$
2 \mathrm{NiOOH}+\mathrm{Cd}+2 \mathrm{H}_{2} \mathrm{O} \underset{\text { Eharge }}{\stackrel{\text { Discharge }}{\longrightarrow}} 2 \mathrm{Ni}(\mathrm{OH})_{2}+\mathrm{Cd}(\mathrm{OH})_{2}
$$


The reversible potential $E_{r}$ of cells can be expressed in terms of the chemical activity of water $\left(\mathrm{a}_{2} \mathrm{O}\right)$ in the electrolyte and the standard cell potential $\left(E^{\circ}\right)$ when all activities of reactants and products are at unit activity:

$$
E_{r}=E^{\circ}-0.059 \log a_{H_{2}} \text { at } 25^{\circ} \mathrm{C} \text {. }
$$

$E^{\circ}$ is 1.290 volts at $25^{\circ} \mathrm{C}$. Thus the voltage of the cycling cell can be influenced by changes in activity (proportional to concentration) of the water in the electrolyte. In hermetically sealed cells oxygen gas is evolved during overcharge from the positive plates of positive limiting cells and recombines chemically with the excess cadmium in the negative plates. Overcharge can occur continuously in well designed cells with no damage to the cell. In vented cells atmospheric oxygen can react with the negative plate active material $(C d)$ and discharge it chemically. Vents must be designed spring loaded to reseal tightly. In addition, carbon dioxide in the air can react with $\mathrm{KOH}$ in the electrolyte to form $\mathrm{K}_{2} \mathrm{CO}_{3}$, and $\mathrm{CdCO}_{3}$ can be formed on the negative plates. Both of these compounds interfere with normal cell operation. Thus, even in vented cells the integrity of the seal is important.

Sintered nickel-cadmium cells have relatively thin sintered nickel matrices as the plate grid structure. These matrices are highly porous and are impregnated with the active positive or negative material in the solution state. The plates are then formed electrochemically, washed and dried. In other variations of the process the active material in 
the sintered matrix is converted chemically, or thermally, to an active state and then formed. In general, there are many steps to these cycles of impregnation and formation and the production lines must be automated $(4-3)$

to reduce cost. Thin sintered plate cells are ideally suited for very high rate charge and discharge service.

Pocket plate nickel-cadmium cells have the positive, or negative active material, pressed into pockets of perforated nickel plated steel $(4-4)$ plates or into tubes. The active material is thus trapped securely in contact with a metal current collector and active material shedding is largely eliminated. Plate designs vary in thickness depending upon cycling service requirements. Lower rate charge-discharge service calls for cells with fewer thicker plates to reduce cost and increase output energy density.

Pocket plate cells may have either a plastic or metal cell case: Metal cell cases must be insulated from each other in a battery cell pack since the cell case is normally the negative cell terminal. Metal cases are preferred for applications requiring high shock and vibration resistance. Plastic cases, normally polypropylene, are preferred for typical'solar PV applications to help eliminate leakage paths to ground.

In long life celis a large excess of electrolyte is contained in cell cases over the plates reducing maintenance for water addition to once in . each two years, depending upon the amount of overcharge and the operating temperature. Flooded cells of this type have low internal gas recombination 
rates. Their covers therefore contain spring loaded pressure relief vents to relieve excess hydrogen and oxygen formed during overcharge. Their venting range is from 2 to 10 psi.

Resealable, vented nickel-cadmium cells are recommended over hermetically sealed cells for solar PV installations because of their much lower cost, although still more expensive than lead acịd cells. Alsn, in series string arrays, unbalanced cells can be brought to the same state of charge more readily by overcharging when vented.

\section{DISCHARGE CHARACTERISTICS OF NICD CELLS}

Discharge curves are similar in shape to lead acid except that cell voltages are lower and range from 1.35 volts initially to a minimum cut-off voltage of 0.85 volts per cell at discharge rates from 10 to 3 hours. Figure 4-1

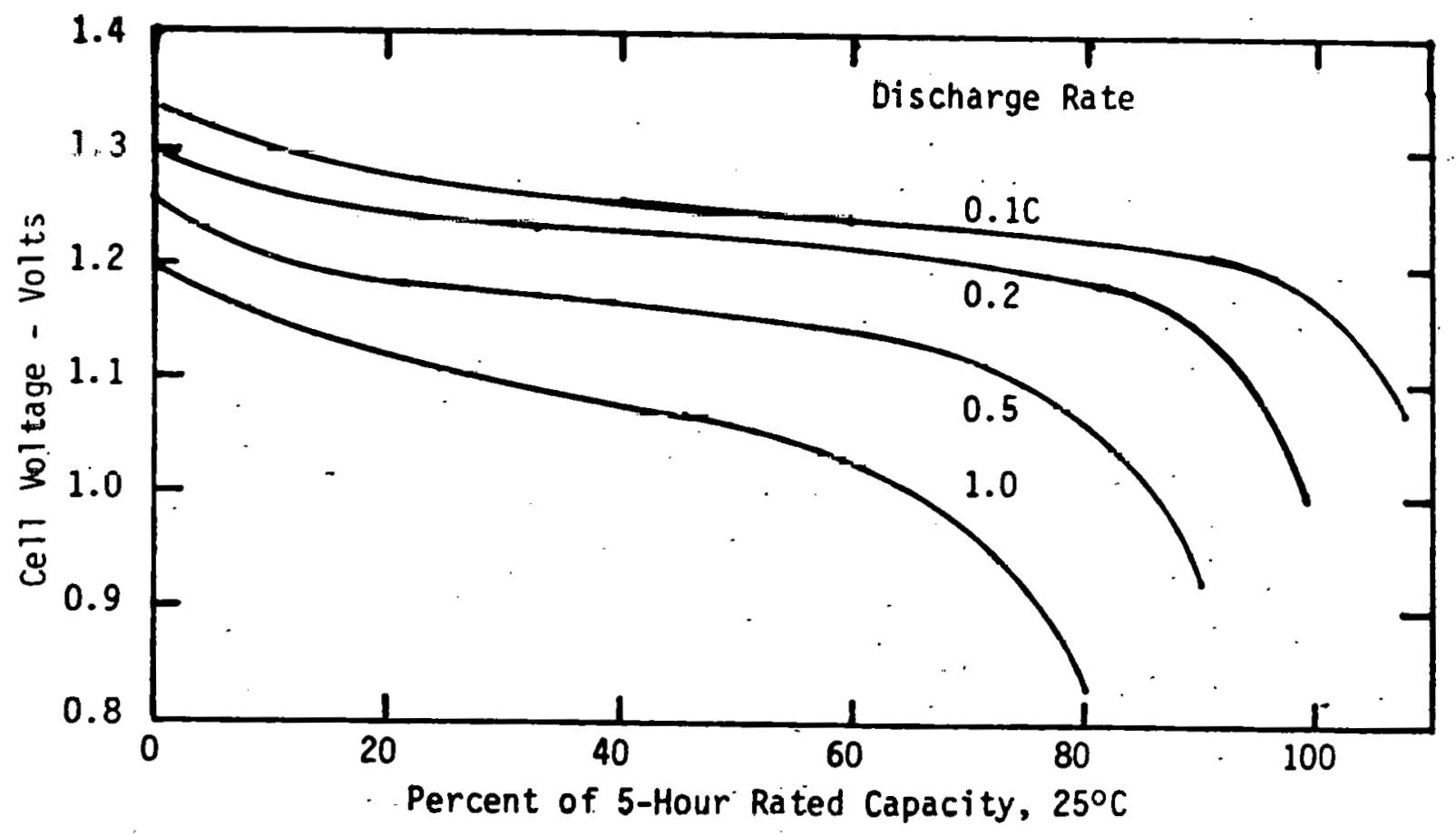

Figure 4-1 Effect of Discharge Rate on Capacity and Voltage Regulation 
gives a family of discharge curves for an intermediate rate pocket plate cell at the $0.1,0.2,0.5$ and $\mathrm{IC}$ rates at $25^{\circ} \mathrm{C}$. The rated capacity (100\% point on the " $\mathrm{X}$ " axis) is the $5-\mathrm{h}$ rated capacity to 1.0 volt at $25^{\circ} \mathrm{C}$. Figure $4-1$ shows that increasing the rate of discharge from the 5-h to the $1-h$ rate decreases capacity from 100 to $68 \%$ of the $5-h$ rated capacity and the average cell voltage falls from 1.23 to 1.13 volts per cell. This change is relatively small and is an advantage of the NiCd system.

Figure 4-2 shows the effect of operating temperature on rated discharge capacity in the temperature range -20 to $25^{\circ} \mathrm{C}$ at the 5,1 and $0.5-h$ discharge rate. Thinner pocket plate cells with greater plate surface area for the same rated capacity would have higher cell voltages and higher percentages of $25^{\circ} \mathrm{C}$ rated capacity at the lower temperatures. To obtain the best cell design for each application the system design engineer should collaborate with the battery manufacturer's application engineer in arriving at the optimum cell construction. 


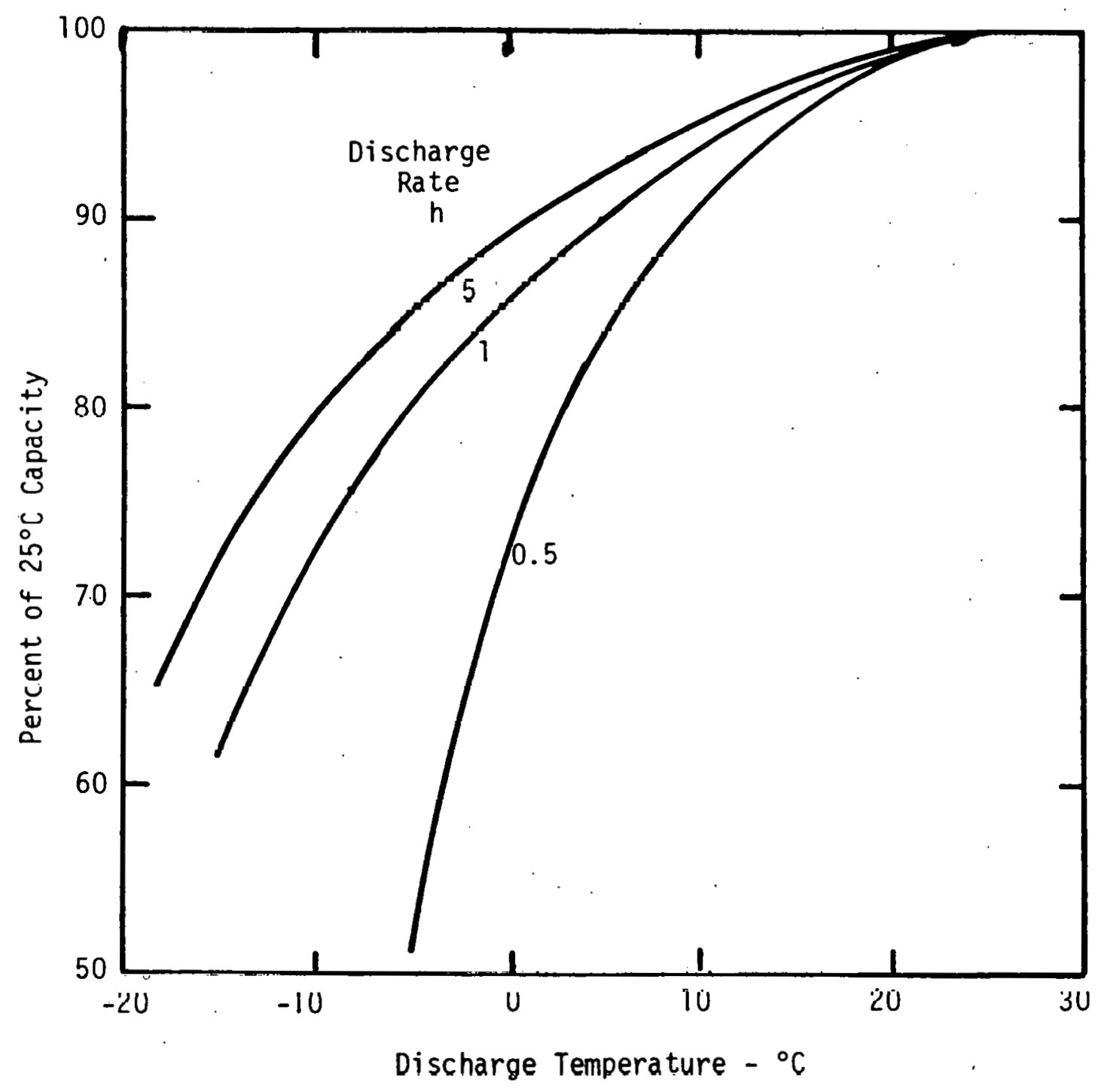

rigure 4-'L - Ettect of Uperating lemperature on Discharge Capacity 
Nickel-cadmi um cells operate well at low temperature provided the electrolyte does not freeze. Table 4-1 gives the freezing temperatures for aqueous $\mathrm{KOH}$ solutions of 20-34 percent $\mathrm{KOH}$.

TABLE $4-1$

Electrolyte Freezing Temperature

\begin{tabular}{c}
$\mathrm{KOH}$ \\
$\begin{array}{c}\text { Concentration } \\
\text { wt\% }\end{array}$ \\
\hline 20 \\
22 \\
24 \\
26 \\
28 \\
30 \\
32 \\
34
\end{tabular}

Particular care has to be taken to assure that cells with lower $\mathrm{KOH}$ concentration electrolyte are not directly exposed to operating temperatures below these freezing points.

Discharge voltages and capacities of sintered plate cells, sealed and vented, can be temporarily lowered by the "memory effect". This lower capacity reduces the time of discharge at a given rate to a predetermined voltage. The effect is brought about by repeated cycles of less than furl capacity. When full capacity is demanded, the cell cannot produce the rated capacity. Generally, the "memory effect" can be erased and full capacity obtained by a small number of complete charge-discharge cycles at $100 \%$ depth of discharge. 
When batteries of both sintered and pocket type are floated at a constant voltage, such as in utility and telephone applications, the negative plate becomes "passive" and less than full capacity is available. Generally, this capacity loss can be restored by a gassing overcharge which is given at a rate of 5-10 A per 100 Ah of the 5-hour rated ampere-hour capacity for 6-12 hours.

\section{CHARGING CHARACTERISTICS}

Nickel-cadmium cells may be charged by constant current, constant potential, or combinations of these methods. Higher charge rates can be tolerated by NiCd cells than by lead-acid cells designed for the same, discharge rate, and rates of $25 \mathrm{~A}$ per $100 \mathrm{Ah}$ of the 5-hour rated capacity are commonly used wi thout harmful effects. One method for cycle application is to recharge at a constant current of $20 \mathrm{~A}$ per $100 \mathrm{Ah}$ to an input 20-40 percent greater than the previous discharge output.

During a typical constant current charge at $20 \mathrm{~A}$ per $100 \mathrm{Ah}$, cell voltage rises from near 1.40 volts to the gassing voltage $(1.45$ volts per cell at $25^{\circ} \mathrm{C}$ ) and then very quick.ly to 1.68 volts, remaining near this voltage during overcharge. See Figure 4-3. 


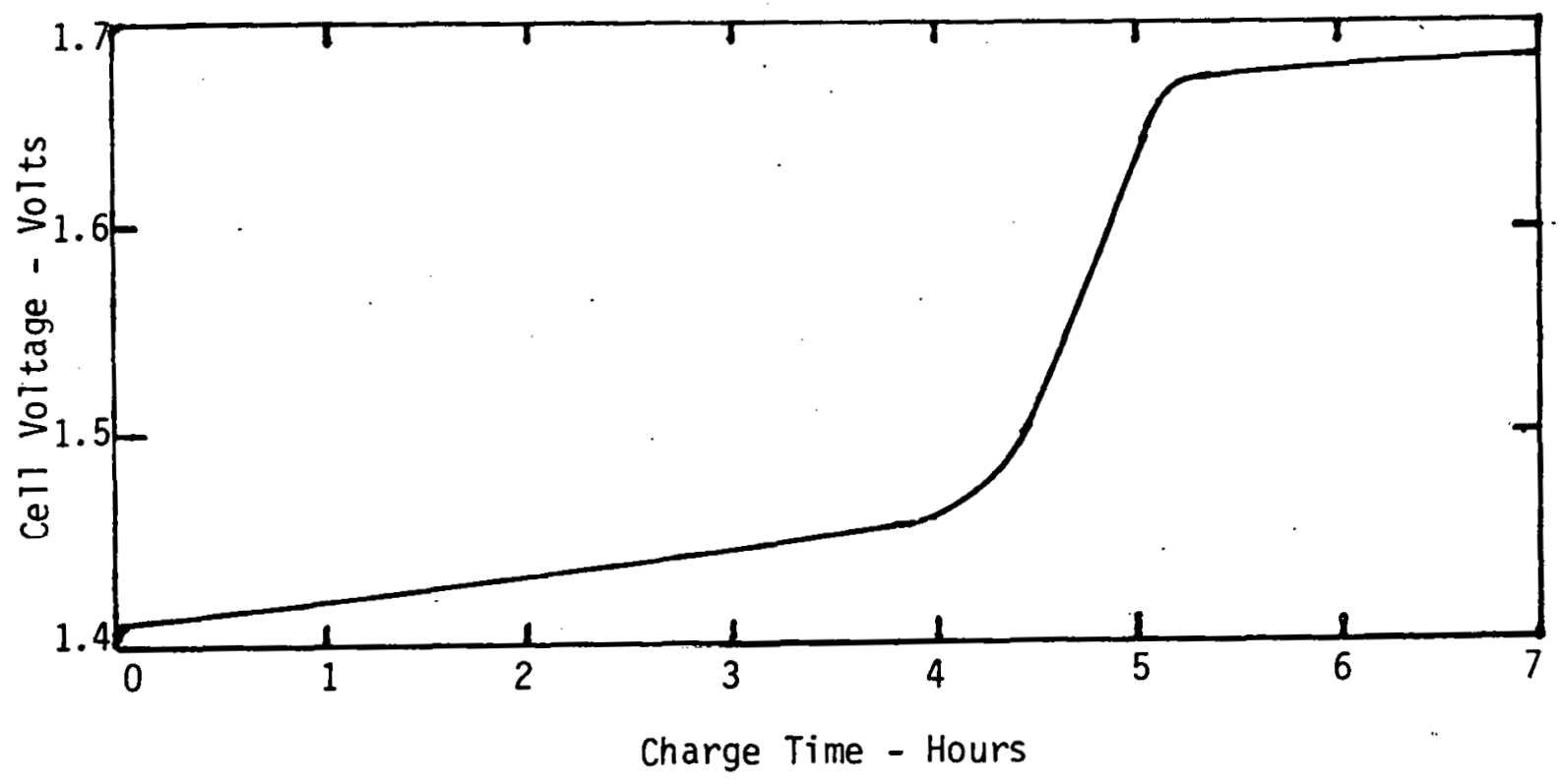

Figure 4-3 Constant Current Charge of Pocket Plate Nickel-Cadmium Cell at $20 \mathrm{~A} / 100 \mathrm{Ah}, 25^{\circ} \mathrm{C}$

The gassing voltage is temperature dependent. In the temperature range $15^{\circ} \mathrm{C}$ to $40^{\circ} \mathrm{C}$ the gassing voltage increases 0.0025 volts for each degree Centigrade increase in electrolyte temperature.

The modified constant potential method of charge is more often recommended for long life cycling regimes in photovoltaic systems. A typical charge starts at constant current $(20 \mathrm{~A}$ per $100 \mathrm{Ah}$ :5-hour rated capacity) and continues at the current until the cell voltage rises to a predetermined voltage limit $\left(1.55\right.$ volts per cell at $\left.25^{\circ} \mathrm{C}\right)$. The voltage. during charge then becomes constant and the current tapers quickly to a final float current. Table 4-2 gives typical charge times and recharge capacity available for the next discharge and assumes a $20 \%$ overcharge. 
TABLE 4-2

Modified Constant Potential Charge Input vs. Rate of Charge Intermediate Rate Pocket Plate Cells

\begin{tabular}{cccccc}
$\begin{array}{c}\text { Depth of } \\
\text { Previous } \\
\text { Discharge } \\
\%\end{array}$ & $\begin{array}{c}\text { Charging } \\
\text { Time } \\
\mathrm{h}\end{array}$ & \multicolumn{5}{c}{$\begin{array}{c}\text { 1.55 Capacity Available } \\
\text { 10A/100AH }\end{array}$} & 20A/100Ah & 10A/100Ah & $20 \mathrm{~A} / 100 \mathrm{Ah}$ \\
\hline \multirow{2}{*}{50} & 6 & 89 & 94 & 92 & 98 \\
& 10 & 92 & 97 & 100 & 100 \\
& 20 & 95 & 94 & 100 & 100 \\
100 & 5 & 57 & 89 & 57 & 93 \\
& 10 & 86 & 95 & 86 & 100 \\
& 20 & 94 & 98 & 100 & 100 \\
\hline
\end{tabular}

Highest rate, thin plate pocket cells show lower voltages during charge at the same charge state, charge rate, and temperature, and can be charged fully in a shorter time period. Charging at temperatures above $45^{\circ} \mathrm{C}$ is harmtul to the active material of the cells.

Modified constant potential charging of pocket plate cells is normally at pre-set voltages of 1.60-1.65 volts per cell to obtain maximum input in the shortest time. After a deep discharge the charge current is constant for the first 4-5 hours, then decays rapidly to less than 10A/100Ah in the first hour and more gradually during the next $4-5$ hours to final float currents. These float currents vary typically with the pre-set voltage limit as follows at $25^{\circ} \mathrm{C}$ :

\begin{tabular}{cc}
$\begin{array}{c}\text { Voltage Limit } \\
\text { volts/cel1 }\end{array}$ & $\begin{array}{c}\text { End-of-Charge Current } \\
\text { A/l00Ah }\end{array}$ \\
\hline 1.50 & 0.5 \\
1.55 & 1 \\
1.60 & 3 \\
1.65 & 10
\end{tabular}


Charge acceptance and charge time are considerably influenced by charge temperature. Lower temperature increases charge time and decreases charge acceptance. At $0^{\circ} \mathrm{C}$, for example, the end-of-charge current will be approximately one-fifth of the $25^{\circ} \mathrm{C}$ value. The solar PV system voltage regulator must be designed with temperature compensated charge voltages to obtain highest charging efficiency.

At $25^{\circ} \mathrm{C}$ ampere-hour charge efficiency is 71 percent for an overcharge of $40 \%$, and turn around energy efficiency would be 60 percent, or lower, at either lower or higher charge temperatures. These inefficiencies are a relative disadvantage fo the NiCd system, and the overcharge required to maintain capacity increases water loss over that required for lead-acid cells.

\section{OPERATING AND CHARGED STAND LIFE}

Life measurements are not available to compare cycle life at various depths of discharge and operating temperatures. Life must be obtained in actual tests on the regime and under the environment of the application. Cycle life increases with decreasing discharge depth. Typical life data for pocket plate NiCd cells is shown on the following (4-7) page. 


\author{
Depth of Discharge \\ at $25^{\circ} \mathrm{C}$ \\ $\%$ of 5 h Rated Capacity
}

20

40

60

80

100
Cycles to Failure

(Capacity Below

$80 \%$ hh Rated Ah)

2500

1700

1100

750

These projections assume continuous $5 \mathrm{~h}$ discharges and controlled charging to restore discharge capacity plus optimum overcharge at $25^{\circ} \mathrm{C}$. At $50^{\circ} \mathrm{C}$ average cycling temperature, life can be $50 \%$ of the above estimates. Under proper maintenance conditions, wet 7 ives of 10-25 years and cycle lives of 1000-4000 at 60-80 percent depth of discharge have been reported.

Charged stand loss in capacity at $-20^{\circ} \mathrm{C}$ is essentially zero but increases with increasing stand temperature and cell plate area per unit capacity. At $25^{\circ} \mathrm{C}$ the loss is 0.1 to $1.0 \%$ per day averaged over 4-6 months, but loss rates during the first 10-20 days will be 1-2\% per day and much lower thereafter. At $45^{\circ} \mathrm{C}$ the loss rate is about 3 times that (4-9)

at $25^{\circ} \mathrm{C}$. Charged stand loss rates of space type thin plate hermetically sealed $\mathrm{NiCd}$ cells were observed to be $0.7 \%$ per day at $0^{\circ} \mathrm{C}, 0.7 \%$ per day (4-10) at $20^{\circ} \mathrm{C}$, and $2 \%$ per day at $30^{\circ} \mathrm{C}$. Conditions which lead to higher charged stand losses are excessive overcharge, high operating and stand temperature, and the contamination of the electrolyte by nitrates and tin.

Increased concentrations of potassium carbonate in the electrolyte will lower discharge voltages, increase charge voltages, decrease charge acceptance and reduce 1 ife. $(4-11)$ 


\section{MAINTENANCE AND SAFETY PRECAUTIONS}

Each battery manufacturer can provide the system designer with detailed service and operating instructions for the battery. This document will include recommendations for periodic maintenance and safety precautions to be followed by the user.

For vented nickel-cadmium cells, the maintenance requirements will be:

1) Watering the cells to supply water lost during overcharge;

2) Maintaining intercell connectors at proper torque; and,

3). Keeping cell tops and exposed sides clean and dry.

In a standby float operation a nickel-cadmium battery will require water additions no more often than every two years. In regimes with considerable overcharge more water will be necessary. In full overcharge maximum water consumption can rise to $0.336 \mathrm{cc} / \mathrm{Ah}$. First, estimate the accumulative overcharge per year, then, calculate the theoretical water consumption and add 5-10\% for evaporative losses. Add this amount each year but do not overfill beyond the manufacturer's recommended upper water line in each cell.

Torque intercell connectors with a torque wrench just up to the torque value recommended by the battery manufacturer. Do not allow metal wrenches to short cell terminals. 
Electrolyte spillage can form grounding paths. White moss around vent cap seal is potassium carbonate $\left(\mathrm{K}_{2} \mathrm{CO}_{3}\right)$. Clean up these surfaces with pure water and dry. In handling the caustic potassium hydroxide electrolyte safety goggles should be worn to protect the eyes and plastic gloves and an apron to protect skin and clothes. In case of spillage on hands or clothes neutralize the alkali immediately with vinegar (3\% acetic acid) or dilute boric acid 3olution (one pound per gallon of water); then rinse with clear water.

During overcharge explosive mixtures of hydrogen and oxygen are formed in nickel-cadmium cells. When the cell relief valves vent these gases to the atmosphere, a potential explosive hazard can exist if sparks or cigarette or lighted matches are nearby. "No Smoking" signs should be posted in battery rooms. As a further safety measure room ventilation can be designed to prevent hydrogen concentration in closed spaces from exceeding one percent by volume. Destructive explosions can occur at concentrations above four percent by volume in air. 


\section{REFERENCES}

4-1 Paul Bauer, "Batteries for space Power Systems", NASA SP-172, 1968.

4-2 IBID, page 70 .

4-3 S. Uno Falk and A. J. Salkind, "Alkaline Storage Batteries", John Wiley \& Sons, Inc., 1969, page 125.

4-4 IBID, page 59 .

4-5 Paul Bauer, "Batteries for Space Power Systems", NASA SP-172, 1968, page 98.

4-6 VARTA, Prospectus 30 - 322e, Nicd Batteries, VARTA Batteries, Inc., Elmsford, N.Y. 10523.

4-7 NIFE, Incorporated, P.O. Box 100, George Washington Highway, Lincoln, R. I., 02865.

4-8 Reference 4-3, page 304 .

4-9 IBID, page 303 .

4-10 IBID, page 404 .

4-1l D. T. Barney, A. J. Catotti and S. F. Pensabene, Power Sources 1970, Preprint Paper 8. 


\section{CHAPTER 5}

\section{BATTERY COSTS IN SOLAR PHOTOVOLTAIC SYSTEMS}

- Lead-Acid System Energy Costs

- Nickel-Cadmium System Energy Costs

- Summary of Annual and Stored Energy Cost Estimates

- References

Work Performed for

The U.S. Department of Energy Sandia National Laboratories Albuquerque, New Mexico 87185 Under Contract No. 13-2202 


\section{CHAPTER 5}

\section{BATTERY COSTS IN SOLAR PHOTOVOLTAIC SYSTEMS}

Depending upon the size and type of solar photovoltaic system, battery subsystem costs may vary from 10 percent to 50 percent of the total system cost. Precise prices can only be obtained through the. competitive bidding process. Advertised list prices are not likely to be timely because material prices fluctuate with market forces. For estimating purposes this study has used published Government Services Administration prices (late 1980) including the mean delivery charge to Zone 1 locations in the United States. These prices include cell, module, electrolyte and intercell connector hardware and are representative of a number of suppliers.

Battery energy costs are expressed in dollars per battery subsystem and dollars per kilowatt-hour $(\$ / \mathrm{kWh})$ of energy delivered at the specified rate and temperature. These costs vary depending upon the following conditions:

Discharge energy costs normally decrease with increasing cell capacity in a line of cells of similar design

- Discharge energy cost increases with increasing charge/ discharge current and decreasing charge/discharge time Discharge energy cost rapidly increases with decreasing charge/discharge temperatures below $25^{\circ} \mathrm{C}$ 
- Above $25^{\circ} \mathrm{C}$, discharge energy costs decrease until energy loss from side reactions becomes significant (around $40^{\circ} \mathrm{C}$ ), then costs increase

- Increasing reserve energy in a battery design will increase single energy costs but may decrease total lifetime energy cost.

Stored energy costs are more difficult to assess. Some applications require relatively few cycles, but wet float lives of 15-20 years are specified, and the battery must. be ahie to deliver its ratcd capacity at any time. For systems of this type the annual cost of stored energy is sometimes a battery subsystem rating factor. The lowest cost battery witl be the battery with the lowest initial price and the longest service time. Other applications demand continuous cycling, and the stored energy output accumulated over all cycles. As an example, consider the relative costs of initial single cycle vs. accumulative cycle energy costs in an automotive starter-light-ignition battery, a golf cart battery and an industrial motive power battery:

Initial

Purchase Price cycle stored Energy Cost

Battery Type

SLI Battery

Golf Cart Battery

Industrial
$\$ /$ kWh

80

80

130
Life

200

500

2000 $\$ / \mathrm{kWh} / \mathrm{cycle}$

.40

.16

.065

The particular application, the load, and the duty cycle will determine discharge energy costs summed over the battery life. Other assuciated costs can also become significant in some applications: i.e., maintenance cost, installation cost and replacement cost. Trade-offs of initial price vs. overall battery life costs can best be made by a team 
effort between the manufacturer's sales and application engineers and the solar PV system designer.

As an aid to the system designer, representative cell, module and battery prices are shown in tables to follow. Estimates of energy costs for a single deep discharge of rated capacity are given; and where the applicable cycle life data can be estimated, stored energy costs in dollars per kilowatt-hour per cycle are calculated.

\section{LEAD-ACID SYSTEM ENERGY COSTS}

Table 5-1 gives cell discharge rate and temperature, energy outputs, and delivered energy costs for a line of lead-calcium batteries with $(5-1)$

pasted flat plates. These batteries are for float applications and have

a 20 year life expectancy. Their annual delivered energy cost at the 8-hour rate ranges from $\$ 9-20 / \mathrm{kWh}$ per year of life. A typical application would require no more than 1-2 rated capacity discharges per year and the remaining cycles are random depth, normally less than $20 \%$ of rated capacity. 
TABLE 5-1

Energy Output and Delivered Energy Cost 50-200 Ah Pasted Flat Plate Lead-Calcium Batteries

\begin{tabular}{|c|c|c|c|c|}
\hline Nominal & \multicolumn{2}{|c|}{ Discharge } & \multirow{2}{*}{$\begin{array}{l}\text { Energy } \\
\text { Output } \\
\text { to } 1.75 \mathrm{~V}\end{array}$} & \multirow{2}{*}{$\begin{array}{l}\text { Delivered } \\
\text { Energy } \\
\text { Cost }\end{array}$} \\
\hline $\begin{array}{l}\text { 8-Hour } \\
\text { Capacity to } 1.75 \mathrm{~V}\end{array}$ & Tempera & Rate & & \\
\hline . Ah & ${ }^{\circ} \mathrm{C}$ & $\mathrm{h}$ & Wh & $\$ / k W h$ \\
\hline$\left(2-\operatorname{cel} 1 \mathrm{In}^{5 n}\right.$ module) & $\begin{array}{r}0 \\
-18\end{array}$ & $\begin{array}{r}500 \\
8 \\
3 \\
1 \\
500 \\
500\end{array}$ & $\begin{array}{r}371 \\
189 \\
144 \\
99 \\
278 \\
148\end{array}$ & $\begin{array}{l}202 \\
396 \\
521 \\
758 \\
269 \\
507\end{array}$ \\
\hline$\frac{100}{(3-\operatorname{cel} l \text { module })}$ & $\begin{array}{r}0 \\
-18\end{array}$ & $\begin{array}{r}500 \\
8 \\
3 \\
1 \\
500 \\
500\end{array}$ & $\begin{array}{l}784 \\
564 \\
431 \\
301 \\
588 \\
314\end{array}$ & $\begin{array}{l}171 \\
238 \\
311 \\
445 \\
228 \\
427\end{array}$ \\
\hline (3-cell module) & $\begin{array}{r}0 \\
-18\end{array}$ & $\begin{array}{r}500 \\
8 \\
3 \\
1 \\
1 \\
500 \\
500\end{array}$ & $\begin{array}{r}1568 \\
1128 \\
860 \\
503 \\
1176 \\
627\end{array}$ & $\begin{array}{l}128 \\
177 \\
233 \\
332 \\
170 \\
319\end{array}$ \\
\hline
\end{tabular}

Table 5-2 gives typical discharge rate, temperature and delivered energy costs for larger cells, (1020-3700 Ah) of the same float type, 20 year life, lead-calcium pasted flat plate construction. These cells are also for standby service, and cycling service is limited to $1-2$ deep cycles per year plus standby cycles normally less than $20 \%$ depth of rated capacity. Their annual delivered energy cost ranges from $\$ 7-9 / \mathrm{kWh}$ per year of service. 


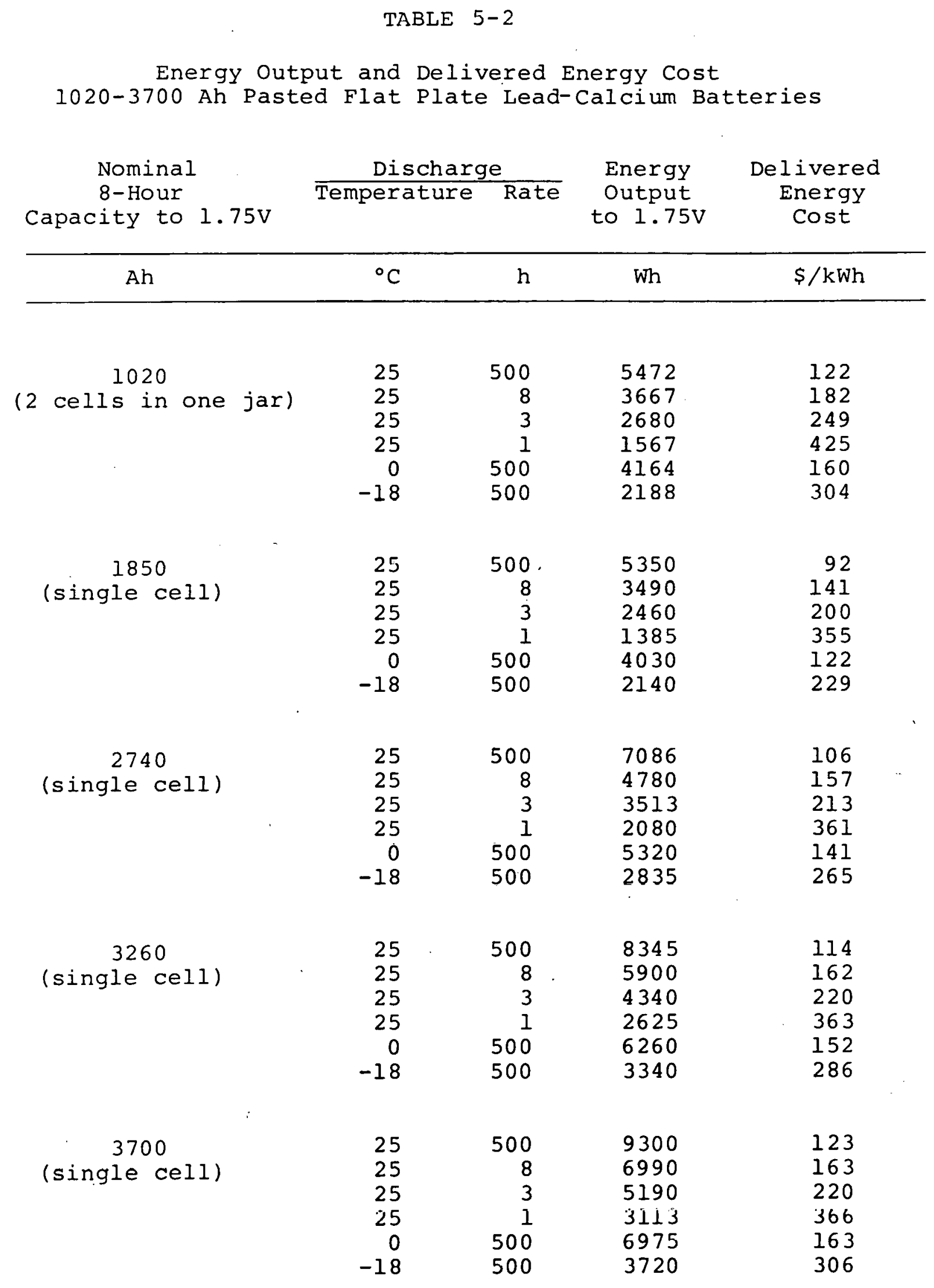


Energy Output and Delivered Energy Cost

50-200 Ah Pasted Flat Plate Lead-Antimony Batteries

$\begin{array}{cccc}\begin{array}{c}\text { Nominal } \\ \text { 8-Hour }\end{array} & \text { Discharge } & \begin{array}{c}\text { Energy } \\ \text { Output Delivered } \\ \text { Energy } \\ \text { Capacity to } 1.75 \mathrm{~V}\end{array} \text { (1) } & \begin{array}{c}\text { Temperature Rate } \\ \text { Cost }\end{array}\end{array}$

\begin{tabular}{|c|c|c|c|c|}
\hline Ah & ${ }^{\circ} \mathrm{s}$ & $h$ & Wh & $s / k W h$ \\
\hline$\left(2-\operatorname{cell}{ }^{50}\right.$ module $)$ & $\begin{array}{r}25 \\
25 \\
25 \\
0 \\
-18\end{array}$ & $\begin{array}{r}500 \\
8 \\
1 \\
500 \\
500\end{array}$ & $\begin{array}{r}249 \\
191 \\
96 \\
187 \\
100\end{array}$ & $\begin{array}{l}301 \\
393 \\
781 \\
401 \\
750\end{array}$ \\
\hline (3-cell module) & $\begin{array}{r}25 \\
25 \\
25 \\
0 \\
-18\end{array}$ & $\begin{array}{r}500 \\
8 \\
1 \\
500 \\
500\end{array}$ & $\begin{array}{l}788 \\
573 \\
282 \\
591 \\
31.5\end{array}$ & $\begin{array}{l}170 \\
234 \\
475 \\
227 \\
425\end{array}$ \\
\hline$(3-\operatorname{cell} 200$ & $\begin{array}{r}25 \\
25 \\
25 \\
0 \\
-18\end{array}$ & $\begin{array}{r}500 \\
8 \\
1 \\
500 \\
500\end{array}$ & $\begin{array}{r}1576 \\
1146 \\
574 \\
1182 \\
630\end{array}$ & $\begin{array}{l}127 \\
175 \\
348 \\
169 \\
317\end{array}$ \\
\hline
\end{tabular}

Tables 5-3 and 5-4 give the same data for pasted flat plate leadantimeny cells plus additional energy output as a function of operating (5-4)

temperature. Delivered energy costs are comparable for lead-calcium and lead-antimony type cells tested under similar conditions. Their wet lives are estimated to be 18-20 years. Their annual delivered energy cost at the 8-hour discharge rate for cells larger than 1000 Ah range from $\$ 7-9 / \mathrm{kWh}$ per year of service. 
TABLE 5-4

Energy Output and Delivered Energy Cost vs. Discharge Rate And Operating Temperature,

Lead-Antimony Pasted Flat Plate Cells

(1020-3700 Ah)

\begin{tabular}{|c|c|c|c|c|c|c|c|c|c|c|c|c|c|c|c|c|c|}
\hline \multirow{3}{*}{$\begin{array}{c}\text { Nominal } \\
\text { B-Hour } \\
\text { Capacity } \\
\text { Ah }\end{array}$} & \multicolumn{9}{|c|}{ Output Energy, wh (2) (3) } & \multicolumn{8}{|c|}{$\begin{array}{c}\text { Delivered Energy Cost } \\
\$ / \mathrm{kWh}\end{array}$} \\
\hline & \multicolumn{3}{|c|}{ 1-h Rate } & \multicolumn{3}{|c|}{ 8-h Rate } & \multicolumn{3}{|c|}{ 500-h Rate } & \multicolumn{3}{|c|}{ 1-h Rate } & \multicolumn{3}{|c|}{ 8-h Rate } & \multicolumn{2}{|c|}{$500-\mathrm{h} 1$} \\
\hline & -18 & 0 & 25 & -18 & 0 & 25 & -18 & 0 & 25 & -18 & 0 & 25 & -18 & 0 & $0 \quad 25$ & -18 & 1 \\
\hline 1020 (1) & 655 & 1228 & 1637 & 1536 & 2000 & 3840 & 2386 & 4476 & 5965 & 1017 & 542 & 406 & 434 & 333 & $\begin{array}{ll}3173 \\
\end{array}$ & 279 & $14 !$ \\
\hline 1850 & 560 & 1051 & 1401 & 13.97 & 2620 & 3493 & 2178 & 4084 & 5445 & 877 & 467 & 350 & 351 & 187 & $7 \quad 141$ & 225 & 126 \\
\hline 2740 & 830 & 1557 & 2076 & 2074 & 3890 & 5186 & 3103 & 5818 & 7757 & 904 & 482 & 361 & 362 & 193 & $\begin{array}{ll}3 \quad 145 \\
\end{array}$ & 242 & 125 \\
\hline 3260 & 1035 & 1941 & 2588 & 2468 & 4627 & 6169 & 3431 & 6433 & 8577 & 922 & 491 & 369 & 387 & 206 & $6 \quad 155$ & 278 & $14 \varepsilon$ \\
\hline 3700 & 1249 & 2342 & 3122 & 2794 & 5239 & 6985 & 3480 & 6525 & 8700 & 913 & 487 & 365 & 408 & 218 & 8163 & 328 & 175 \\
\hline
\end{tabular}

Notes: (1) 2-Cell Module; All Others Single Cells

(2) Operating. Temperature; ${ }^{\circ} \mathrm{C}$

(3) Output Energy at 0 and $-18^{\circ} \mathrm{C}$ Estimated 
Table 5-5 gives energy output and delivered energy costs for cells with pure lead alloy grids and relatively thicker pasted flat plates designed for $(5-5)$

low rate service. This data is derived from tests on cells at the $10 \mathrm{~A}$ rate and the 500-hour rate over the temperature range $-40^{\circ} \mathrm{C}$ to $25^{\circ} \mathrm{C}$.

\section{TABLE 5-5}

Energy Output and Delivered Energy Cost

Pure Lead Low Rate Charge Retaining Batteries

$$
(110-600 \mathrm{nh})
$$

\begin{tabular}{|c|c|c|c|c|c|c|c|c|}
\hline \multirow{2}{*}{\multicolumn{2}{|c|}{$\begin{array}{c}\text { Discharge } \\
\text { Rate }\end{array}$}} & \multirow{3}{*}{$\begin{array}{l}\text { Discharge } \\
\text { Temperature }\end{array}$} & \multirow{2}{*}{\multicolumn{2}{|c|}{$\frac{\text { Cell Size, E }}{\ln \mathrm{Ah}}$}} & \multirow{2}{*}{\multicolumn{2}{|c|}{$\frac{\text { Energy Output, }}{220 \mathrm{Ah}}$}} & \multicolumn{2}{|c|}{ Energy Cost $(1)$} \\
\hline & & & & & & & 600 & \\
\hline $\begin{array}{c}\text { Time } \\
\mathrm{h}\end{array}$ & $\begin{array}{c}\text { Current } \\
\text { A }\end{array}$ & & $\begin{array}{c}\text { EItEL yy } \\
\text { Wh } \\
\text { (1) }\end{array}$ & $\begin{array}{l}\text { Cust } \\
\$ / \mathrm{kWh}\end{array}$ & $\begin{array}{l}\text { Energy } \\
\text { Wh } \\
\text { (2) }\end{array}$ & $\begin{array}{l}\text { Cust } \\
\$ / \mathrm{kWh}\end{array}$ & $\begin{array}{l}\text { Energy } \\
\text { Wh } \\
(2)\end{array}$ & $\begin{array}{l}\operatorname{cost} \\
\$ / k W h\end{array}$ \\
\hline & 10 & $\begin{array}{r}25 \\
0 \\
-18 \\
-40\end{array}$ & $\begin{array}{r}223 \\
167 \\
89 \\
82\end{array}$ & $\begin{array}{r}354 \\
473 \\
888 \\
1274\end{array}$ & $\begin{array}{r}102 \\
77 \\
41 \\
29\end{array}$ & $\begin{array}{r}549 \\
727 \\
1366 \\
1931\end{array}$ & $\begin{array}{r}309 \\
232 \\
124 \\
87\end{array}$ & $\begin{array}{r}362 \\
493 \\
903 \\
1287\end{array}$ \\
\hline 500 & & $\begin{array}{r}25 \\
0 \\
-18 \\
-40\end{array}$ & $\begin{array}{l}653 \\
490 \\
261 \\
183\end{array}$ & $\begin{array}{l}121 \\
161 \\
303 \\
432\end{array}$ & $\begin{array}{l}431 \\
323 \\
172 \\
120\end{array}$ & $\begin{array}{l}130 \\
173 \\
326 \\
467\end{array}$ & $\begin{array}{r}1188 \\
891 \\
475 \\
333\end{array}$ & $\begin{array}{r}94 \\
126 \\
236 \\
336\end{array}$ \\
\hline
\end{tabular}

Notcs: (1) Energy output to 1.75 volts per cell; 3 cells in series

(2) Single cell

This type of cell is used in Coast Guard navigational buoys and structures and is charged daily by solar photovoltaic panels. Current requirements range from 0.30 to $3.0 \mathrm{~A}$ on a 10-30 percent duty cycle. The larger of these cells offers attractive low cost $(\$ 94 / \mathrm{kWh})$ and long life. Pure lead grids have an exceptionally low open circuit stand capacity loss of 15 percent per year. 
The normal recharge time is 75 hours. When discharged to 100 percent depth at the 500-hour rate, only 15 cycles can be performed in a year. At other rates and discharge depths these charge retaining cells can deliver the estimated cycle life and wet life shown in Figure 5-1. In float service the annual energy cost ranges from $\$ 8$ to $11 / \mathrm{kWh}$ per year during a 12 year life. In cycle service the accumulative stored energy cost for the 600 Ah size cell, with a delivered single cycle delivered energy cost of $\$ 94 / \mathrm{kWh}$, will be $25 \mathrm{c}$ to $35 \mathrm{c} / \mathrm{kWh} /$ cycle during a 7.5 year life and one $10 \%$ to $20 \%$ depth cycle per day. Stored energy costs rapidly increase with increasing depth of discharge and decreasing cycles per year. This cell type offers attractive opportunities for the solar PV system designer.

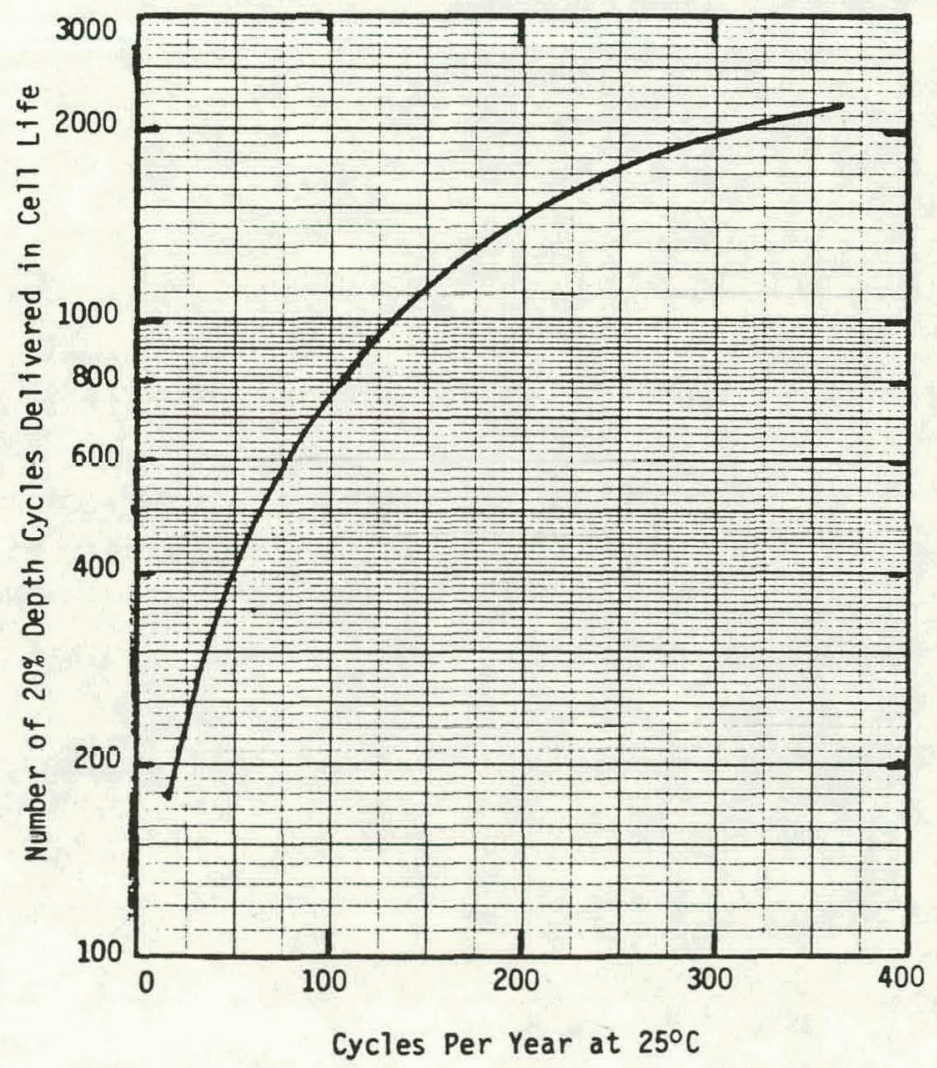

Figure 5-1 Shallow Cycle Life of Low Rate, Pure Lead Flat Plate Cells, Charge Retaining Type, 110-600 Ah Size Range 
Industrial motorized truck batteries are designed for high cycle service. Table 5-6 summarizes output energy at the typical lift truck rate of 6 -hours to $1.75 \mathrm{~V}$, delivered energy cost in $\$ / \mathrm{kWh}$, and the accumulative stored energy cost for a line of 12 volt lead-antimony, tubular positive truck batteries in the capacity range 220-400Ah.

$$
\text { I'ABLE } \supset-6
$$

Encrgy Output, Delivered and Stored Energy Cost 220-770 Ah Lead-Antimony Tubular Positive Motorized Truck Cells

\begin{tabular}{ccccc}
$\begin{array}{c}\text { Nominal } \\
6 \text {-Hour } \\
\text { Capacity }\end{array}$ & $\begin{array}{c}\text { Energy } \\
\text { Output } \\
6 \text {-Hour Rate } \\
\text { to } 1.75 \mathrm{~V} \\
\mathrm{kWh}\end{array}$ & $\begin{array}{c}\text { Delivered } \\
\text { Energy } \\
\text { Cost }\end{array}$ & \multicolumn{2}{c}{$\begin{array}{c}\text { Stored Energy Cost } \\
\$ / \mathrm{kWh} / \text { cycle }\end{array}$} \\
Ah & $\$ / \mathrm{kWh}$ & $20 \%$ DOD & & \\
\hline 220 & 2.58 & 207 & .26 & $80 \%$ DOD \\
330 & 3.84 & 171 & .21 & .17 \\
440 & 5.16 & 157 & .20 & .14 \\
550 & 6.42 & 151 & .19 & .13 \\
660 & 7.68 & 148 & .19 & .13 \\
770 & 9.00 & 144 & .18 & .12 \\
& & & & .12
\end{tabular}

Notes: (1) 4000 cycles at $20 \%$ of rated 6 -hour capacity

(2) 1500 cycles at 80 o of rated 6-hour capacity on a WB-133B specification Test 2 cycles per day at room ambient

Energy costs for an excellent general purpose lead-antimony tubular positive cell line, which thrives on cycling and float service, is given in Table 5-7. 
TABLE 5-7

Energy Output, Delivered and Stored Energy Cost

760-2130 Ah Lead Antimony, Tubular Positive General Purpose Cells

\begin{tabular}{|c|c|c|c|c|c|c|c|c|}
\hline \multirow{2}{*}{$\begin{array}{l}\text { Nominal } \\
\text { 8-Hour } \\
\text { Capacity }\end{array}$} & \multirow{2}{*}{$\begin{array}{r}\begin{array}{r}\text { Energy } \\
\text { (to }\end{array} \\
72-h\end{array}$} & \multicolumn{2}{|c|}{$\begin{array}{l}\text { Output-kWh } \\
1.75 \mathrm{VPC})\end{array}$} & \multicolumn{3}{|c|}{$\begin{array}{c}\text { Delivered Energy Cost } \\
\$ / k W h\end{array}$} & \multicolumn{2}{|c|}{$\begin{array}{c}\text { Stored Energy cost } \\
\$ / \mathrm{kWh} / \text { cycle (1) }\end{array}$} \\
\hline & & $8-h$ & $1-h$ & $72-h$ & $8-h$ & $1-h$ & $20 \div \mathrm{DOD}$ & $80 \% \mathrm{DOD}$ \\
\hline & & & & & & & $(8-h)$ & $(8-h)$ \\
\hline $\begin{array}{r}760 \\
1060 \\
1370 \\
1670 \\
2130\end{array}$ & $\begin{array}{l}2.08 \\
2.91 \\
3.74 \\
4.57 \\
5.83\end{array}$ & $\begin{array}{l}1.44 \\
2.02 \\
2.60 \\
3.18 \\
4.04\end{array}$ & $\begin{array}{l}0.59 \\
0.82 \\
1.06 \\
1.29 \\
1.64\end{array}$ & $\begin{array}{l}149 \\
132 \\
124 \\
124 \\
120\end{array}$ & $\begin{array}{l}215 \\
190 \\
178 \\
178 \\
174\end{array}$ & $\begin{array}{l}524 \\
467 \\
438 \\
441 \\
427\end{array}$ & $\begin{array}{r}.27 \\
.24 \\
.22 \\
.222 \\
. .22\end{array}$ & $\begin{array}{l}.18 \\
.16 \\
.15 \\
.15 \\
.15\end{array}$ \\
\hline
\end{tabular}

Notes: (1) Estimated cycle life at $25^{\circ} \mathrm{C}$ to $80 \%$ rated 8-h capacity: $20 \%$ DOD, 4000 cycles; 808 DOD, 1500 cycles.

These cells are recommended for applications where cycling depth is not predictable, where variable rate discharges ( 1 minute to 3 hours) are expected and where a 22 year life expectancy in shallow cycling can be an advantage. 
Energy costs for a line of lead-antimony pasted flat plate cell designs for industrial motive power and lift trucks are given in Table 5-8. $(5-9)$

TABLE 5-8

Energy Output, Delivered and Stored Energy Cost

225-1200 Ah Lead-Antimony, Pasted Flat Plate Mntive Power Colls

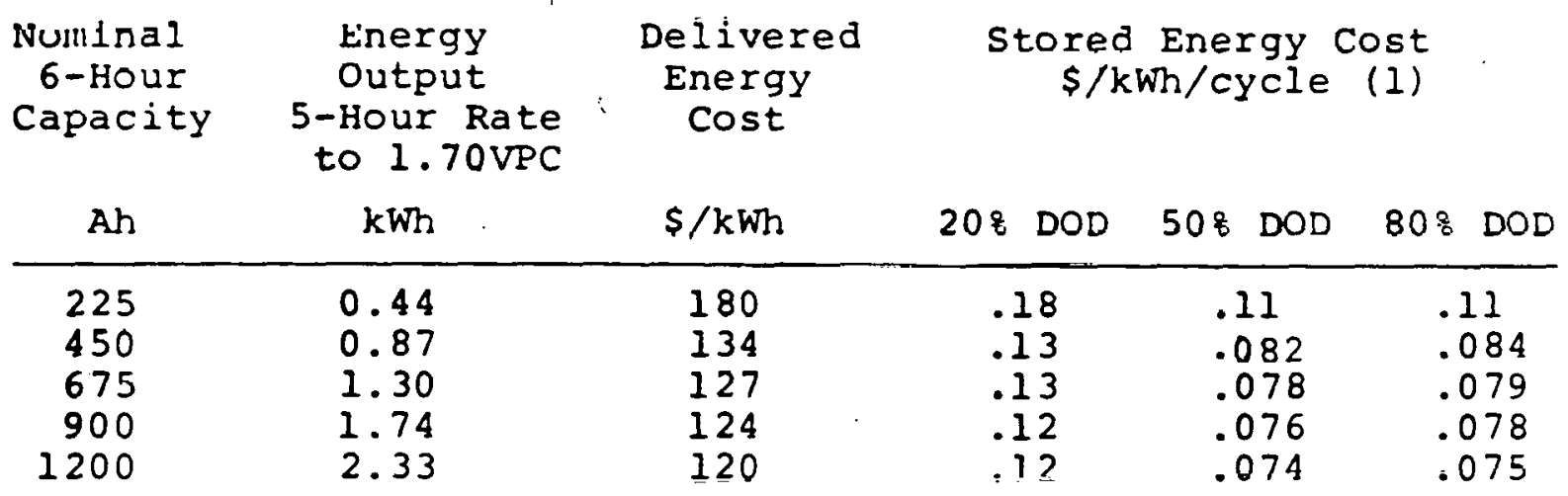

Notes: (1) Estimated cycle life to 808 rated 5-hour capacity: 208 DOD, 5,000 cycles; $50 \%$ DOD, 3,250 cycles; 808 DOD, 2,000 cycles on a WB $133 \mathrm{~B}$ test regime.

Cells of this type have a construction ideally suited for continusus cycling at a rate of $1-2$ deep $(80 \%)$ cycles per day.

Cycling tests on lead-calcium motive power cells are in progress, and some product lines have been introduced to customers.

Their cycle life, when properly charged by special methods required for the lead-calcium system, is expected to approach two-thirds of the cycle life of lead-antimony cells of a similar type cycled to the same depth. The higher stored energy costs resulting from a lower 
cycle life will be compensated by lower water consumption and lower maintenance costs. Golf cart and electric vehicle batteries are designed for 1-2 years service of one relatively deep cycle per day under ambient conditions. Cycle life varies with golf course terrain and average operating temperature. Electric vehicle battery development is aimed at increasing cycle life and energy density, not cost reduction; however, mass production of this battery type provides competitive costs attractive to the solar PV system designer. One manufacturer limits wet $(5-10)$ life to 500 days. This restriction limits cycle life in the typical PV system to 500 cycles at one cycle per day. Table 5-9 gives estimated delivered and stored energy costs for two popular golf cart, EV 6V batteries. At $80 \%$ depth of discharge their lowest stored energy cost is $14-15$ cents per kilowatt-hour per cycle.

\section{NICKEL-CADMIUM SYSTEM ENERGY COSTS}

Delivered and stored energy costs for pocket plate type nickelcadmium cells are given in Table 5-10. These cells are designed primarily for standby and starter service but also provide a reasonable cycle life.

$\begin{array}{cc}\begin{array}{c}\text { Depth of Discharge } \\ \%\end{array} & \frac{\begin{array}{c}\text { Number of Cycles } \\ \left(25^{\circ} \mathrm{C}\right)\end{array}}{100} \\ 60 & 500 \\ 20 & 1100 \\ 2500\end{array}$

Nickel-cadmi um cells of this type have been in service for more than 40 years. Annual energy costs nevertheless are equal to or greater than comparable lead-acid size cells. 
TABLE 5-9

Energy Output, Delivered and stored Energy Cost

6 Volt Electric Vehicle Type Lead-Antimony Flat Plate Batteries

\begin{tabular}{|c|c|c|c|c|c|c|c|}
\hline \multirow{2}{*}{$\begin{array}{l}\text { Nominal } \\
\text { 3-Hour EV } \\
\text { Capacity } \\
\text { Ah } \\
\end{array}$} & \multirow{2}{*}{$\begin{array}{c}\text { Discharge } \\
\text { Rate } \\
\text { h }\end{array}$} & \multirow{2}{*}{\multicolumn{2}{|c|}{$\begin{array}{c}\text { Energy } \\
\text { Output } \\
\text { to } 1.70 \text { VPC } \\
(1) \\
\text { IwII } \\
\end{array}$}} & \multirow{2}{*}{$\begin{array}{c}\text { Delivered } \\
\text { Energy Cost } \\
(1-C y c l e) \\
(2) \\
\$ / k W l_{1}\end{array}$} & \multicolumn{3}{|c|}{$\begin{array}{c}\text { Stored Energy cost } \\
\$ / \mathrm{kWh} / \text { Cycle } \\
(3)\end{array}$} \\
\hline & & & & & $\begin{array}{l}20 \% \\
D O D\end{array}$ & $\begin{array}{l}50 \% \\
\text { DOD }\end{array}$ & $\begin{array}{l}80 \% \\
\text { DOD }\end{array}$ \\
\hline 110 & $\begin{array}{r}72 \\
2.4 \\
12 \\
6 \\
3\end{array}$ & & $\begin{array}{l}1.09 \\
0.99 \\
0.89 \\
0.79 \\
0.64\end{array}$ & $\begin{array}{l}48.5 \\
53.6 \\
59.7 \\
67.2 \\
83.0\end{array}$ & $\begin{array}{r}1.70 \\
.80 \\
.60 \\
.67 \\
.83\end{array}$ & $\begin{array}{l}.68 \\
.32 \\
.24 \\
.27 \\
.33\end{array}$ & $\begin{array}{l}.42 \\
.20 \\
.15 \\
.17 \\
.21\end{array}$ \\
\hline 133 & $\begin{array}{r}72 \\
24 \\
112 \\
6 \\
3\end{array}$ & & $\begin{array}{l}1.22 \\
1.11 \\
1.01 \\
0.91 \\
0.77\end{array}$ & $\begin{array}{l}48.0 \\
52.7 \\
57.9 \\
64.3 \\
76.0\end{array}$ & $\begin{array}{r}1.68 \\
.79 \\
.58 \\
.64 \\
.76\end{array}$ & $\begin{array}{l}.67 \\
.32 \\
.23 \\
.26 \\
.30\end{array}$ & $\begin{array}{l}.42 \\
.20 \\
.14 \\
.16 \\
.19\end{array}$ \\
\hline
\end{tabular}

Notes: (1) Golf cart and electric vehicle type cell design, 3 vells per battery.

(2) GGA prices late 1980, Zune 1 delivery

(3) Assumes 12-hour recharge, 500 days maximum wet life, and no more than I cycle per day. 
TABLE $5-10$

Nicd Pocket Plate Cell Output Energy And

Stored Energy Costs vs. Discharge Rate

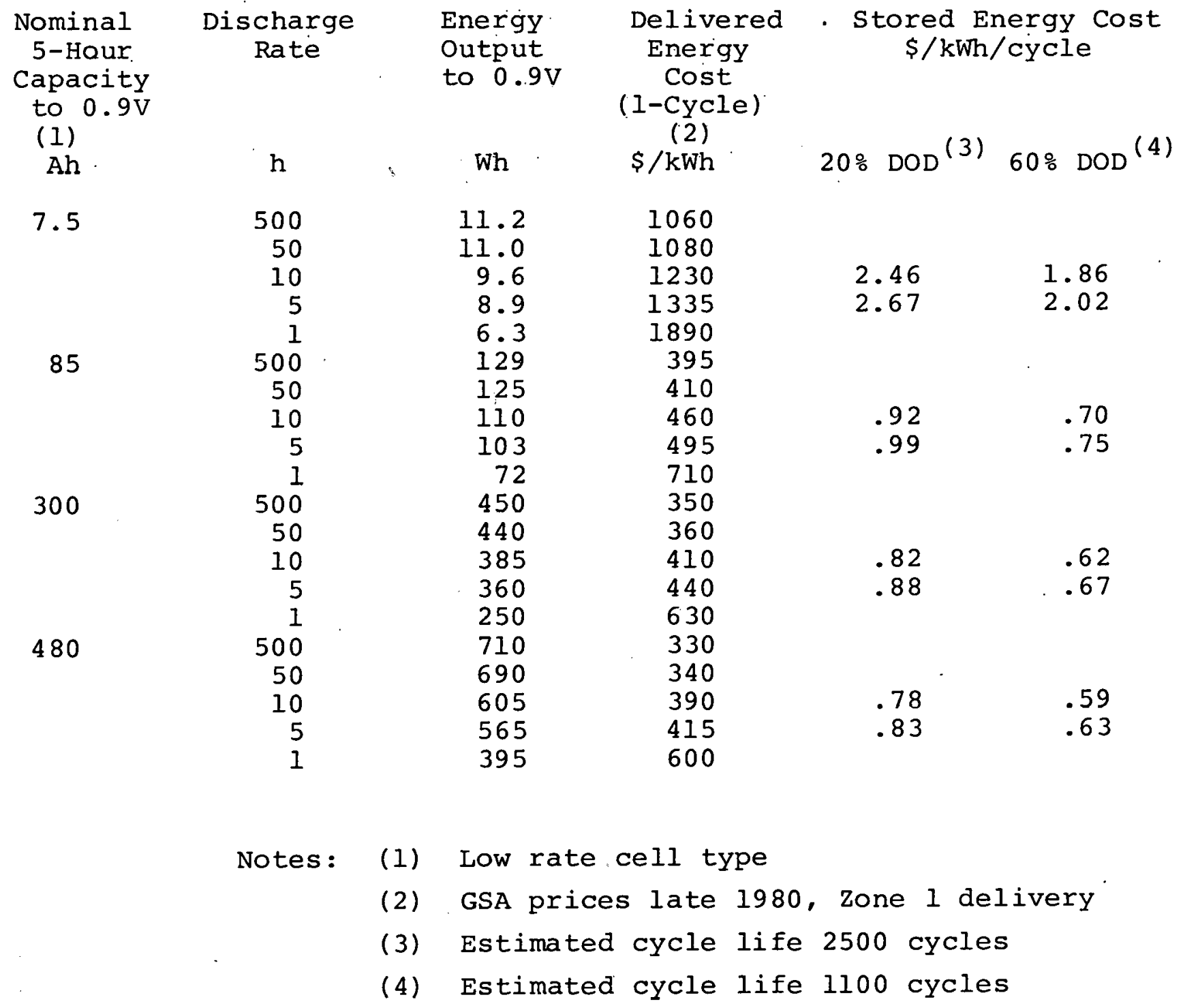




\section{SUMMARY OF ANNUAL AND STORED ENERGY COST ESTIMATES}

Data from Tables 5-1 through 5-10 are summarized in Table 5-11A and $B$ to compare the delivered one-cycle energy cost, the annual energy cost and the accumulative stored energy cost for each of the two electrochemical systems (lead-acid and nickel-cadmium) and for each of the construction types. From this data the solar PV system designer can select the lowest cost battery which is most likely to perform best to the system requirements. 
TABLE 5-11A

Summary of Battery Subsystem Annual and Stored Energy Costs $\underline{\text { Lead-Acid System }}$

\begin{tabular}{|c|c|c|c|c|c|c|c|c|}
\hline \multirow{3}{*}{$\begin{array}{l}\text { Battery Type } \\
\text { and Service }\end{array}$} & \multirow{3}{*}{$\begin{array}{l}\text { Capacity } \\
\text { Range } \\
\text { (1) } \\
\text { Ah }\end{array}$} & $\begin{array}{c}\text { Discharge } \\
\text { Rate }\end{array}$ & \multirow{3}{*}{$\begin{array}{c}\text { Delivered } \\
\text { Energy } \\
\text { Cost } \\
(2) \\
\text { s/kwh }\end{array}$} & \multirow{3}{*}{$\begin{array}{c}\text { Annual } \\
\text { Energy } \\
\text { Cost } \\
(3) \\
\text { s }\end{array}$} & \multicolumn{4}{|c|}{$\begin{array}{c}\text { Stored Energy } \\
\$ / k W h / C y c l e \\
(4)\end{array}$} \\
\hline & & at $25^{\circ} \mathrm{C}$ & & & $20 \%$ & $50 \%$ & $80 \%$ & \\
\hline & & $\mathrm{h}$ & & & DOD & DOD & DOD & \\
\hline
\end{tabular}

- Float Service

Pasted Flat Plate

$\underline{\mathrm{Pb}-\mathrm{Ca}}$

$500-200$

$\begin{array}{rrr}500 & 130-200 & \\ 8 & 180-400 & 9-20 \\ 500 & 92-125 & \\ 8 & 160-180 & 7-9\end{array}$

$\underline{\mathrm{Pb}-\mathrm{Sb}}$

$$
1020-3700
$$

$50-200$

$\begin{array}{rr}500 & 130-300 \\ 8 & 140-170\end{array}$

$7-9$

Float Service Float Service Float Service Float Service Float Service Float Service

- Shallow Cycle Service Pure Lead

$110-600 \quad 500$

$94-130$

.20

.75

.50

.90

Low Rate

- General Purpose

Cycle Service

$\mathrm{Pb}-\mathrm{Sb}$, Tubular 760-2130

Positive Plate

$\begin{array}{rr}72 & 120-149 \\ 8 & 174-215 \\ 1 & 427-524\end{array}$

$8-10$

.22

.15

- Motive Power

Heavy Cycle Service

$\mathrm{Pb}-\mathrm{Sb}$, Tubular 220-770

Pb-Sb, Flat Plate 225-1200

$\mathrm{Pb}-\mathrm{Sb}, \mathrm{EV}$.

$110-133$

$\begin{array}{rcc}6 & 144-207 & 10-17 \\ 5 & 120-180 & 10-15 \\ 12 & 58-60 & \\ 3 & 76-83 & \end{array}$

$\begin{array}{llc}.18-.26 & .12-.17 \\ .12-.18 & .08-.11 \\ .58 & .23 & .14 \\ .76 & .30 & .19\end{array}$

Notes: (1) 3-8 hour rate depending upon service condition

(2) Energy delivered to 1.70 VPC at rated discharge current, $25^{\circ} \mathrm{C}$

(3) Delivered energy cost per year of estimated wet life

(4) Initial battery price divided by accumulated energy output during cycle life at $25^{\circ} \mathrm{C}$. 
TABLE 5-11B

Summary of Battery Subsystem Annual and Stored Energy Costs

Nickel-Cadmium System

\begin{tabular}{|c|c|c|c|c|c|c|}
\hline \multirow[b]{2}{*}{$\begin{array}{l}\text { Uatteiy 'lype } \\
\text { and Service }\end{array}$} & \multirow{2}{*}{$\begin{array}{c}\text { Capacity } \\
\text { Rangn } \\
(1) \\
\text { Āh }\end{array}$} & \multirow{2}{*}{$\begin{array}{c}\text { Discharge } \\
\text { Ratin } \\
\text { at i"u"C } \\
\text { h } \\
\end{array}$} & \multirow{2}{*}{$\begin{array}{c}\text { Delivered } \\
\text { Energy } \\
\text { coot } \\
\langle 2\rangle \\
\$ / \text { kWh }\end{array}$} & \multirow{2}{*}{$\begin{array}{l}\text { Annual } \\
\text { Energy } \\
\text { cost } \\
(3) \\
\$ / \mathrm{kWh} / \mathrm{yr} \\
\end{array}$} & $\begin{array}{r}\text { Stored Er } \\
\$ / k W h / c \\
(4)\end{array}$ & $\begin{array}{l}\text { rgy Cost } \\
\text { cle }\end{array}$ \\
\hline & & & & & $\begin{array}{l}20 \% \\
\text { DOD }\end{array}$ & $\begin{array}{l}80 \% \\
\text { DOD }\end{array}$ \\
\hline - Pocket & $85=480$ & 500 & $330-395$ & $8-10$ & & \\
\hline Plato & & 50 & $340-410$ & & & \\
\hline & & 10 & $390-460$ & $10-12$ & & \\
\hline & $\therefore$ & 5 & $415-495$ & & $.80-.99$ & $.63-.75$ \\
\hline & & 1 & $600-710$ & & & \\
\hline
\end{tabular}

\footnotetext{
Notes: (i) 5 -hour rate to $0.9 \mathrm{VPC}$

(2) Enerigy delivered to 0.9VPC on rated capaaity tcct new at $25^{\circ} \mathrm{C}$

(3) Delivered energy cost per yeax of estimated float lite at $2 b^{\circ} \mathrm{C}$

(4) Initial cell price divided by accumulated energy output during oyolc lifc at $25^{\circ} \mathrm{C}$.
} 


\section{REFERENCES}

5-1 Exide Stationary Batteries and Chargers, Calcium Flat Plate Types LC-CC, Section 51.10.

5-2 IBID, Types GU, Section 51.45.

5-3 IBID, Antimony Flat Plate Types LA-CA, Section 52.10.

5-4 IBID, Antimony Flat Plate Types GT, Section 52.40.

5-5 WISCO Charge Retaining Batteries, WISCO Division, Exide Corporation, 2510 North Boulevard, Raleigh, North Carolina, 27604.

5-6 Evaluation of Lead-Acid Secondary Batteries for Application in U.S. Coast Guard Aids to Wavigation, WQEC/C80-32, Weapons Quality Engineering Center, Crane, Indiana, 47522.

5-7 Exide Batteries and Chargers for Industrial Trucks, Section 20.02.

5-8 Exide Stationary Batteries and Chargers, Lead Antimony Tubular Positive Plate Type, Section 53.15.

5-9 Exide Batteries and Chargers for Industrial Trucks, Dynaclad Type Lead-Acid Cells, Section 20.10.

5-10 Exide Renewable Energy Batteries, Section 93.10, March 1981, Exide Corporation 101 Gibraltar Road, Horsham, Pennsylvania, 19044

5-11 NIFE Incorporated Batteries and Power Systems, NiCd Block Battery Technical Data, Lincoln, R. I., 02865. 


\section{CHAPTER 6}

\section{CHARGERS AND VOLTAGE REGULATORS}

- Basic Voltage Regulator

- Photovoltaic System Battery Charge Control

- Series Pass Voltage Regulator

- Shunt Regulators

- Switching Regulators

- Step-Down Series-Switch Converter/Regulator

- Step-Up Shunt Switch Converter/Regulator

- Comparison of Voltage Regulators

- Series-Pass Voltage Regulator

- Shunt Voltage Regulator

- Step-Down Series Switch Regulator

- Step-Up Shunt Switching Regulator

- Cost/Performance Trade-0ffs

- References

Work Performed for The U.S. Department of Energy Sandia National Laboratories Albuquerque, New Mexico 87185 Under Contract No. 13-2202 


\section{CHAPTER 6}

\section{CHARGERS AND VOLTAGE REGULATORS}

Voltage regulator circuits are essential elements in solar photovoltaic systems utilizing batteries for energy storage. The voltage regulator's function is to regulate the current from the solar panel array to the battery to provide optimum current control during charge.

The output of the voltage regulator must have the same electrical characteristics as a good battery charger. Voltage regulators can vary from a simple, manually controlled resistor between the battery and the photovoltaic panel array to complex, temperature compensating electronic circuits. Cost vs. performance trade-offs must account for concerns such as battery life and capacity, efficiency, power density, reliability, maintainability, size and weight.

Wi thout a voltage regulator, proper charge conditions for the battery cannot be achieved readily. If the solar array is sized to provide sufficient current to charge the battery fully on a daily basis, severe overcharging could occur wi thout some means to regulate the current when only a partial recharge is required. Excessive overcharge would reduce battery life and increase system cost by requiring more frequent battery replacements. 
Conversely, if a solar panel array is sized only to provide a maintenance of finishing charge current, the charge time following a deep discharge might be too long to recharge a battery in the specified time.

This chapter will review the main characteristics of four different types of voltage regulators as a guide for selecting the best type for a given application. Detailed design information will be referenced, and sufficient circuit examples will be given to illustrate design principles.

\section{BASIC VOLTAGE REGULATOR}

Every voltage regulator consists of four basic elements:

(1) a stable reference voltage;

(2) a voltage sampling element;

(3) a voltage comparator, and

(4) a power dissipating control device.

This basic system is shown in the block diagram of Figure 6-1. 


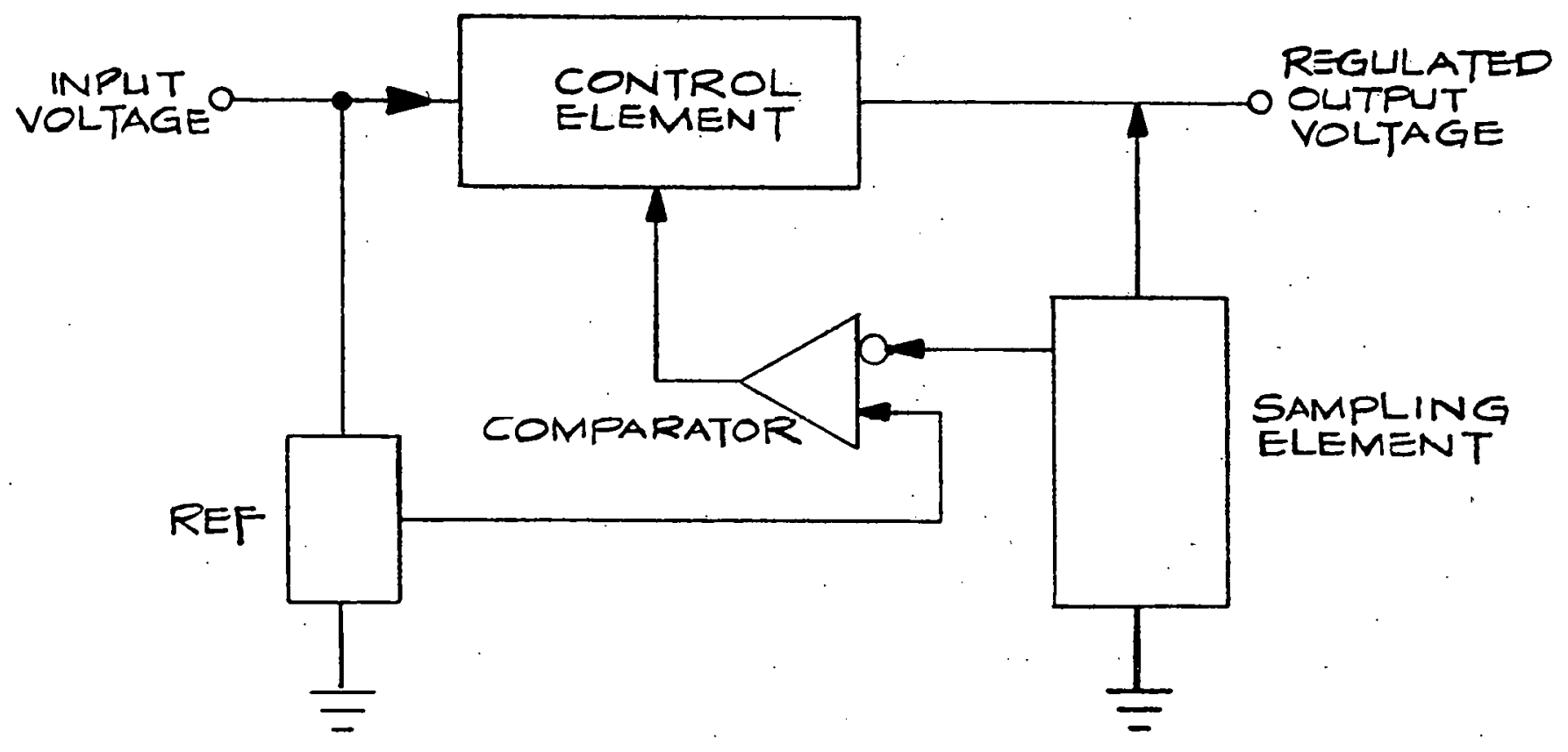

Figure 6-1 Basic Regulator Block Diagram ${ }^{1}$

(Courtesy of Texas. Instruments, Inc.) 
The voltage sampling element translates the output voltage down to a level that will be equal to the reference voltage for a particular output voltage. Then, as the output voltage varies, the sampled voltage changes to a value more or less than the reference voltage. The voltage difference is sensed by the comparator element which generates an crror signal. This signal is dmplified and directs the power dissipating control element to perform the desired requlation function. The control element has normally one of four types of circuitry:

- Series pass

- Shunt

- Series switching

- Shunt switching

Voltage regulators obtain their names from the type of circuitry in the control element. Figure $6-2$ shows schematic configurations for each of the four control circuits.

[Figure $6-2$ is shown on the following page] 


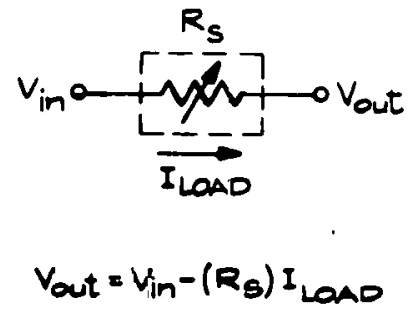

ì

SERIES PASS
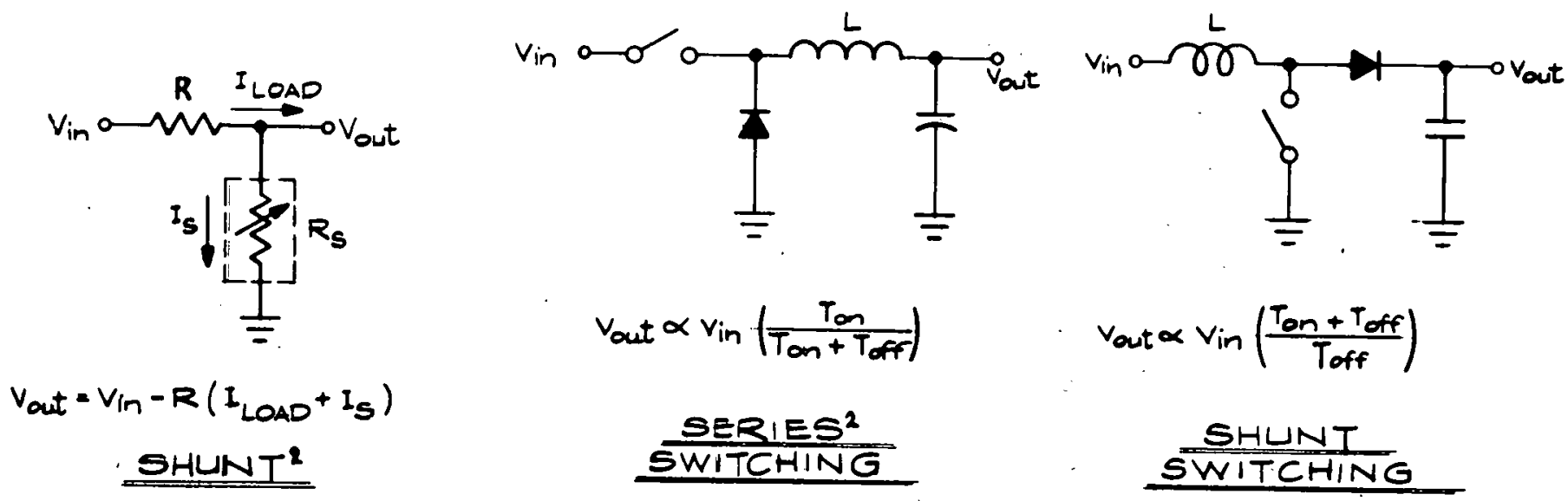

Figure 6-2 Control Element Configurations ${ }^{2}$

(Courtesy of Texas Instruments, Inc.) 
PHOTOVOLTAIC SYSTEM BATTERY CHARGE CONTROL

In photovoltaic system applications, the regulator-PV (Photovoltaic) array acts like a constant current source limited by the array short circuit current when the battery capacity is low. As the battery approaches full capacity, the regulator/array system behaves as a constant voltage source. The regulator can be designed to turn itself off when full capacity is reached. In fact, with the apprnpriate control circuitry, almost any charge current vs. time curve can be approximated by the regulator. Figure $6-3 \mathrm{~A}$ shows the more desirable charge current. vs. time patterns and their corresponding battery voltage vs. time response.

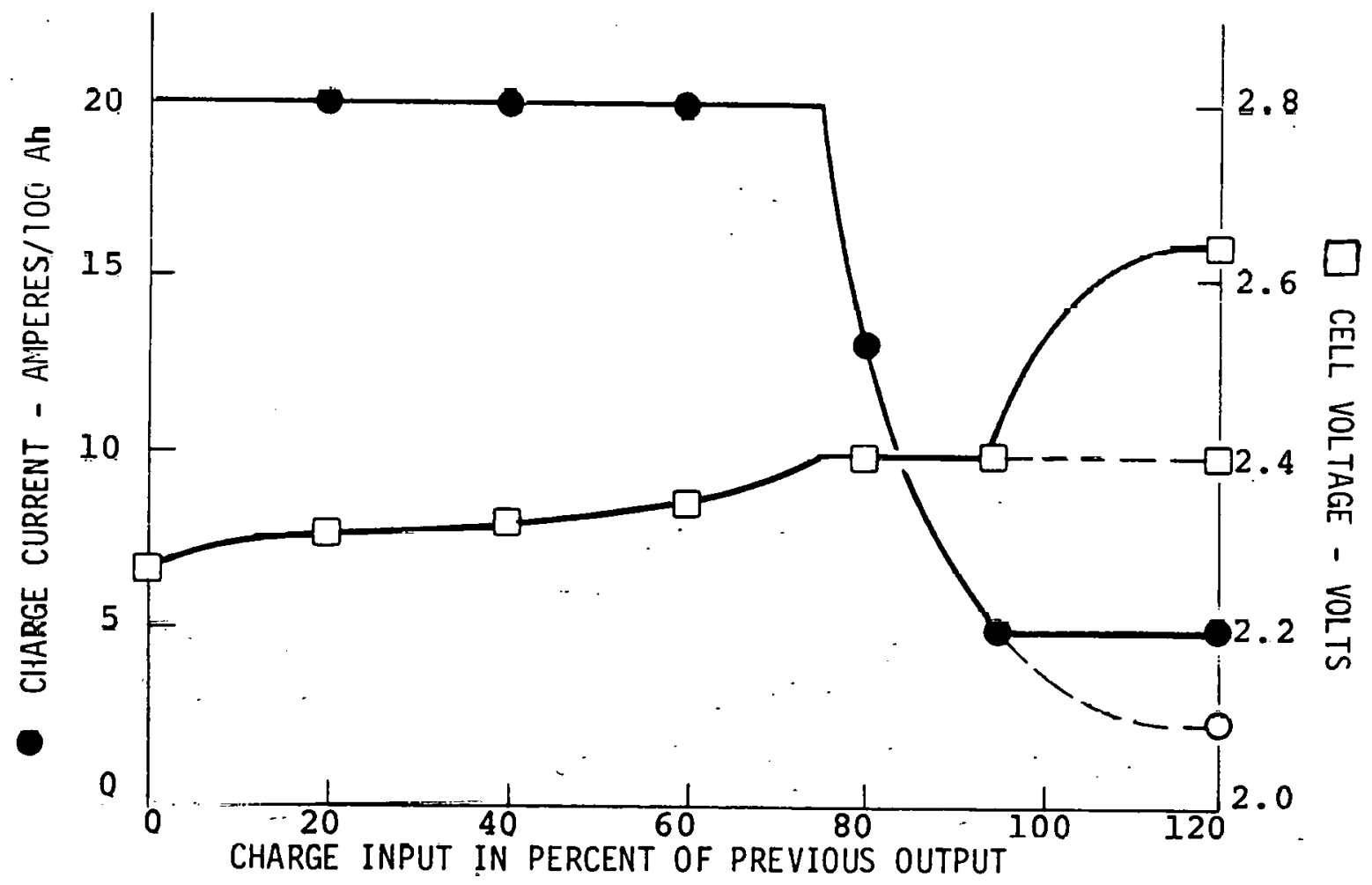

Figure 6-3A Cell Voltage and Current During Charge 
In these charge patterns, the initial current remains constant until the average cell voltage reaches the gassing voltage where appreciable electrolysis of water begins. The current then decays at this constant voltage, $V_{\text {gas, }}$ until charge is terminated (dotted lines of Figure $6-3 A$ ) or until the predetermined finishing rate is reached. At this point the voltage may be decontrolled and the current maintained constant for a predetermined time before terminating the charge. In this case (solid lines of Figure 6-3A), the average cell charging voltage can rise to a value of 2.65 volts per cell, or greater depending on the finishing rate and battery type.

Figure $6-3 B$ shows a graph of the photovoltaic array current vs. vol tage.

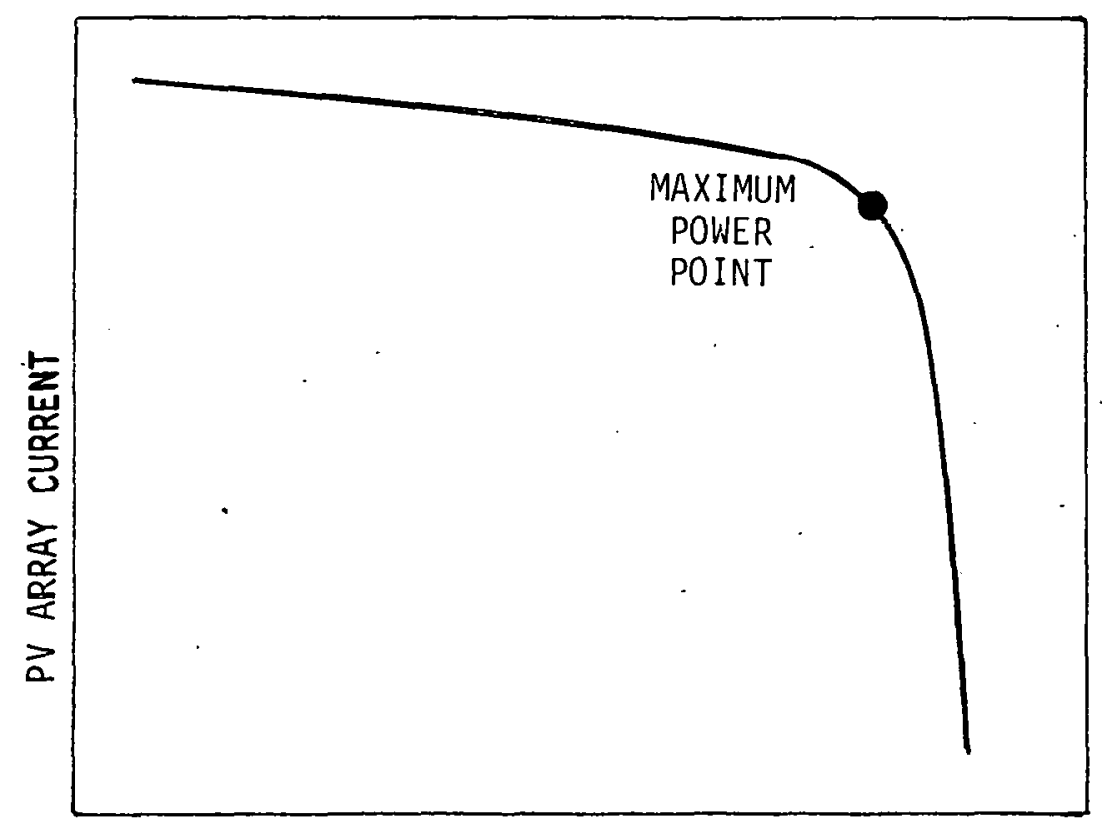

PV ARRAY VOLTAGE

Figure 6-3B Typical Solar Array Current vs. Vol tage Output 
It is desirable to size and operate the PV array as close as possible to the maximum power point to minimize the cost and size of the array. If the operating point is chosen at a voltage much lower than the maximum power point (Figure 6-3B), the PV array will be operating at very low efficiency at the end of charge. Conversely, if the operating point is chosen much greater than the maximum power point, there is a הanger that the insufficient current will be availatile llidr the end of charge. This would have the effect of extending the time required to fully -charge the battery. The voltage regulator in general should approximate the characteristics of a constant voltage/constant current dc power supply. During the initial portion of the charge, the current would remain limited by the output of the array. When the battery gassing point is reached, the regulator shnuld reduce the current to the battery so that the gassing voltage is maintained until near the end of charge.

The gassing voltage changes with temperature. See Table 6-1 for values from +50 to $-20^{\circ} \mathrm{C}\left(+122\right.$ to $\left.-4^{\circ} \mathrm{F}\right)$. The regulator must compensate for this change in gassing voltage with temperature to avoid over:charging at high temperature and undercharging at low temperature. If a reference voltage is made constant over the operating temperature range by use of precision volt tage reference chip or a precision Zener diode (less than $10^{\circ} \mathrm{PPM} /{ }^{\circ} \mathrm{C}\left(5.6 \mathrm{PPM} /{ }^{\circ} \mathrm{F}\right.$ variation)), a thermister can be used in the sampling network to compensate for temperature variations 
in battery voltage. Precision resistors are used in the sampling network for accuracy. Thermistors are available with both negative and positive coefficients, thus permitting several sampling network configurations.

A blocking diode should be placed between the PV panel array and the regulator to prevent the battery from discharging through the array in time of total darkness and zero panel output.

The major features of the four types of voltage regulator control circuits can now be reviewed to make comparisons in their performance.

\section{SERIES PASS VOLTAGE REGULATOR}

A typical series pass voltage regulator circuit is shown in Figure 6-4 on the following page.

A variable input dc voltage is translated into a lower constant voltage by the series-pass element which consists of one or more transistors in parallel. As the source voltage varies, the effective resistance of the series element is increased or decreased, so that it absorbs the change in source voltage. Control of the series-pass transistor(s) is accomplished by the negative feedback loop conșisting of the resistor sampling network, the difference amplifier, and the voltage amplifier and level shifter. 


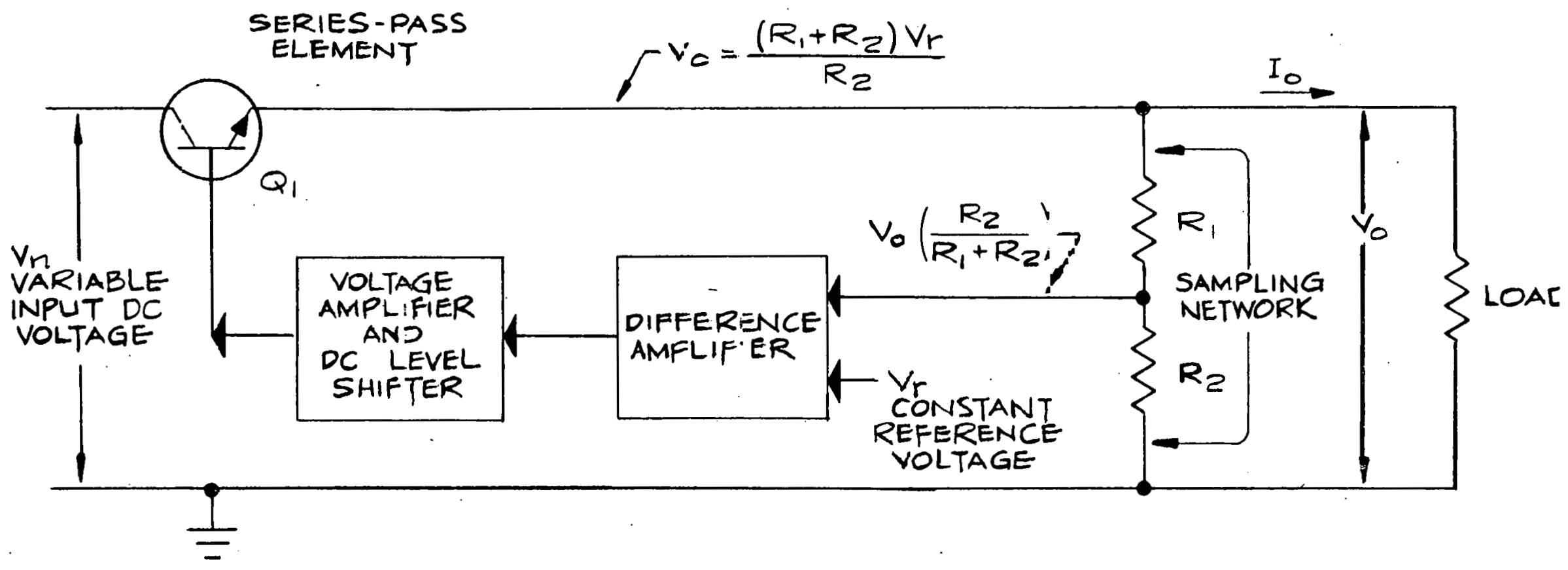

Figure E-4 Basic Series - Pass Voltage Regulator. $Q_{1}$ is an Eiev-tronically Controlled Variable Resistance in Series with the Load. ${ }^{3}$

(Courtesy of Hayden Book Company, Inc.) 
The sampled output voltage $v_{0}\left(\frac{R_{2}}{R_{1}+R_{2}}\right)$ is compared to the constant reference voltage, $V_{r}$. An error is generated by the difference amplifier that is proportional to the difference between the sampled output voltage and $V_{r}$. This error voltage is amplified and level shifted to drive the series-pass transistor. A small increase in output voltage causes an increase in the series-pass element impedance to maintain a constant output voltage. Likewise, a small decrease in output voltage will cause the impedance of the series-pass transistor to decrease. The negative feedback loop always maintains the sampled output voltage $v_{0}\left(\frac{R_{2}}{R_{1}+R_{2}}\right)$ very nearly equal to $v_{r}$.

With the use of several parallel series-pass transistors, the seriespass regulator can handle up to 2000 watts of power. Above that power level, unequal current sharing by the series-pass transistors and voltage drops across interconnecting wiring limit the applicability of this design.

\section{SHUNT REGULATORS}

The basic shunt regulator, shown in Figure 6-5, converts a variable higher voltage dc to a constant lower voltage dc by using a shunt element, consisting of one or more parallel transistors, as a variable resistance device. As the input rises or falls, the effective resistance of the shunt element is increased or decreased, thereby shunting more or less of the current away from the load. The shunt is controlled to provide a constant output voltage by the negative feedback loop composed of the 
resistor sampling chain, the difference amplifier, and the voltage amplifier, level-shifter element.

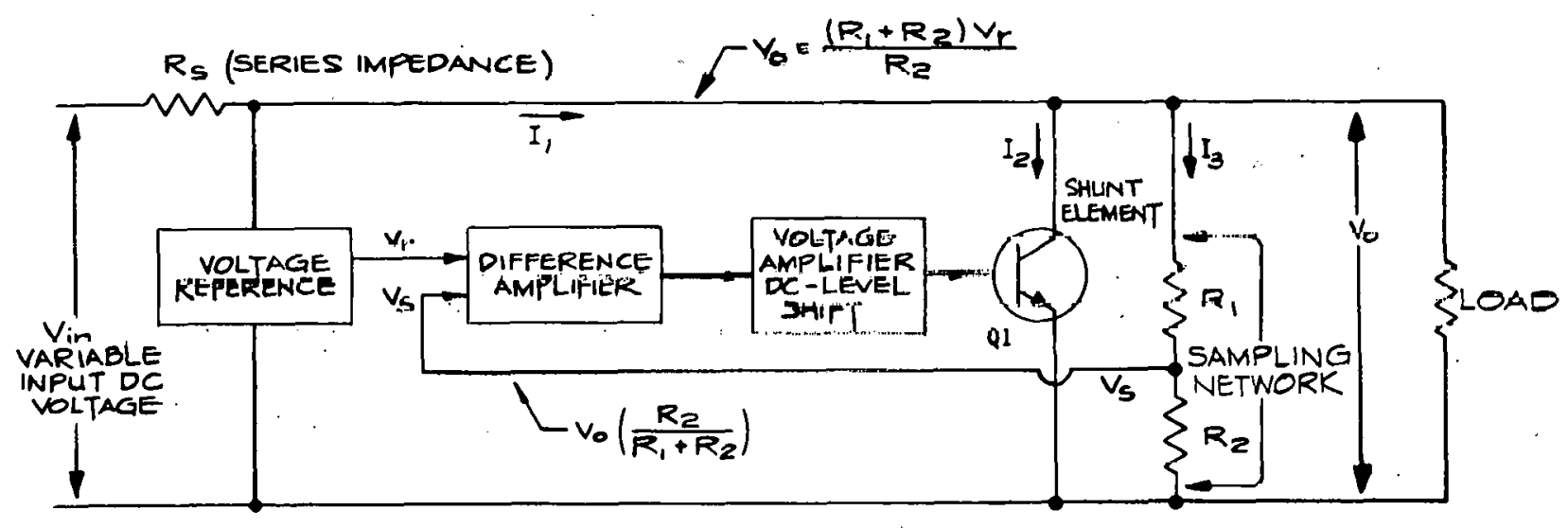

Figure 6-5 'Basic Shunt Regulator

A fraction of the output voltage $\frac{R_{2}}{R_{1}+R_{2}} \times V_{0}$ is sampled and compared to a constant reference voltage, $V_{r}$. The difference amplifier yleilds a voltage proportional to the difference between $V_{r}$ and the output sample. The amplified difference voltage is further amplified and the dc level shifted to drive the input terminal of the shunt element. Voltage polarities are such that a small increase or decrease in output voltage resulting from line or load changes causes the correct decrease or increase, respectively, in shunt element impedance to keep the output constant. The output adjusts itself so that the sampled fraction is very nearly equal to the reference voltage.

Even though it is usually. less efficient than the series-pass regulator, a shunt regulator may prove to be the best choice for a specific application. It is less sensitive to input voltage transients, 
does not reflect load current transients back to the source, and is inherently short circuit proof.

Shunt regulators can be used in a master-slave arrangement for increased power handling up to 1000 watts. A master shunt regulator operates normally except that it also drives other paralleled shunting devices (slaves) which are mounted on their own heat sinks. In this way, the master controls the slave and the power can be more easily dissipated.

Equal current sharing in the power transistors can become a problem, and the betas of large power handling devices must be closely matched. The power dissipated by each succeeding slave decreases due to voltage drop losses in the interconnecting wiring. These two problems limit shunt regulators to less than 1000 watts.

\section{SWITCHING REGULATORS}

Switching regulators are used where large input.-to-output differential voltages may exist, or where high load current requirements are necessary. Their use is particularly suited for high power applications, and systems where efficiency is important. Two basic switching regulators are shown in Figure 6-6. 


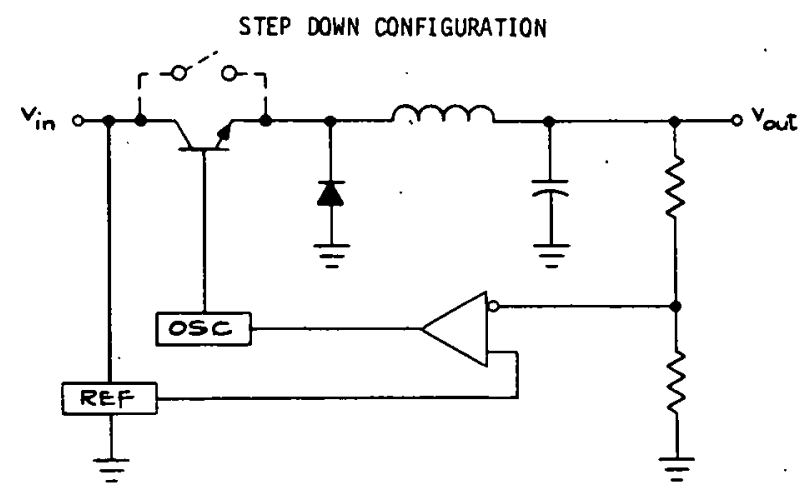

(Courtesy of Texas Instruments, Inc.)

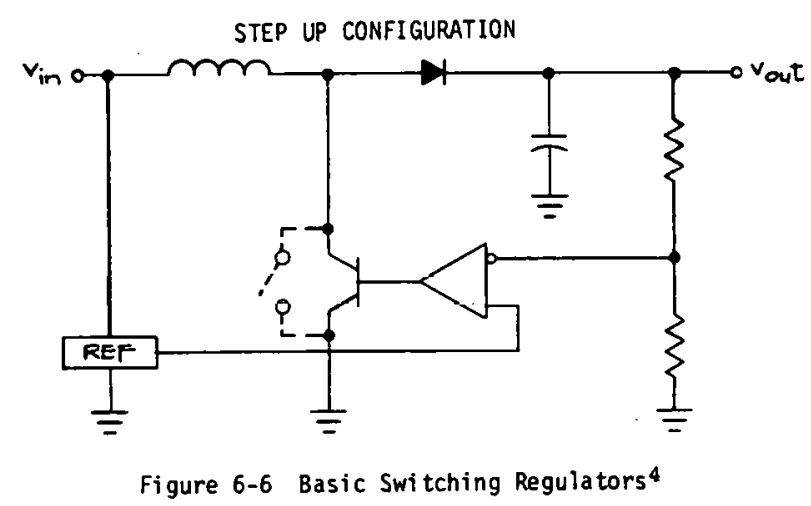

In a switching regulator, an active device (such as a switching transistor) is used to chop the input voltage or current to meet the load requirements. This is accomplished by varying the duty cycle of the switching transistors. This can be accomplished in three ways:

1. Varying the frequency with a constant "on" time

2. Varying the frequency with a constant "off" time

3. Varying the "on" and "off" times with a constant frequency Method No. I simplifies regulator design, because the energy stored in the inductor during the "on" time is fixed and determines the power deliverable to the load. The calculation of inductor size is relatively easy, since the operating window of the inductor is well-defined. The operating frequency of the regulator varies with the load. 
An LC filter normally averages the regulator output voltage as perceived by the load. The switching power transistor is operated in the saturated mode where it is either "on" or "off".

Method No. 2 will provide operation at a well-defined minimum frequency under full-load conditions. It also reduces the ripple current and maintains the Eame averigr ruprent undor illurudicd londing, by allowing a dc current to flow in the inductor. However, precautions should be taken concerning the problem of inductor saturation.

Method No. 3 is usually taken because it is easier to filter the noise or EMI (electromagnetic interference) generated by the switching regulator when it is at a fixed frequency. This approach also rcsults in a dc inductor current (for increased loads) to maintain the required current transferred with minimal ripple.

In designing switching regulators, one may. select discrete components or use one of several monolithic switching regulator circuits that are currently available. In low power applications, the complete regulator is included on a single IC (integrated circuit) chip; by adding larger external power elements (such as a switching transistor, a free-wheeling diode, and necessary driver components to adequately drive the transistor), many kilowatts of power can be regulated by the IC chips: Supervisory IC 
chips are also available for almost all of the control logic, such as overvoltage protection, undervoltage protection, current limiting, and current sensing.

\section{STEP-DOWN SERIES-SWITCH CONVERTER/REGULATOR}

The switching operation of a basic step-down converter is shown in Figure 6-7. A low impedance transistor is opened and closed periodically between the input and the output.

Since the collector-emitter voltage drop of the transistor when it is the saturated "on" state (normally closed) is very small compared to the system output voltage, it will be assumed to be zero. Then the output will periodically vary between zero volts and the input voltage, with the average value of this waveform being $V_{0}-V_{i n} \frac{T_{0 n}}{T}$ where $T_{\text {on }}$ is the time that the transistor switch is "on" and $T$ is the switching period. The ripple voltage still has a peak-to-peak value of $V_{\text {in }}$. However, adding the $L_{1} C_{1}$ filter reduces the ripple to an acceptable level. The filter components required become smaller as the switching frequencies increase to the $20-50 \mathrm{kHz}$ range.

The switching duty cycle, defined as $\frac{T_{0 n}}{T}$, means that by varying the duty cycle, any output voltage lower than the input can be obtained. Efficiency is high, since the only losses in the converter occur in the switching transistor when it is "on". These losses are insignificant because the voltage drop across the transistor when it is "on" is at 

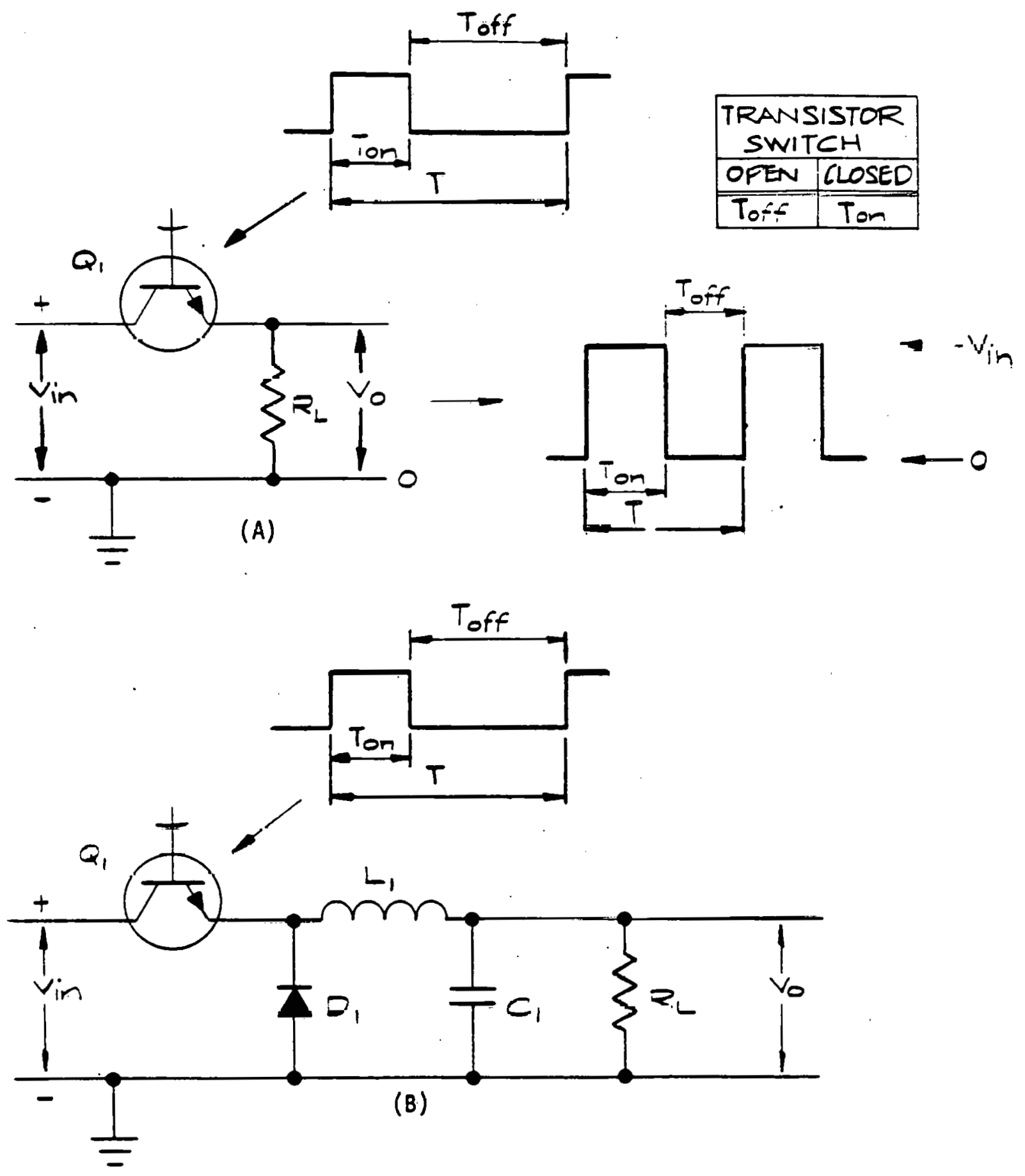

Figure $6-7$ (A) SWITCHING VOLTAGE CONVERTER AVERAGE OUTPUT VOLTAGE AT $V_{0}=\operatorname{Vin}\left(\frac{\text { Ton }}{T}\right) .5$

(B) SWITCHING VOLTAGE CONVERTER WITH LC FILTER AND DIODE FOR ELIMINATING RIPPLE.5

(Courtesy of Hayden Book Company, Inc.) 
$V_{\text {ce }}$ (SAT) or approximately 1 volt. There is no power dissipation when the transistor is "off" because no current flows through it.

When the transistor switch turns "off", the input side of $L_{1}$ goes negative because current cannot change instantaneously through an inductor. Diode $D_{1}$ starts conducting when $i$ ts cathode potential becomes sufficiently negative to cause the diode to become forward biased. When the transistor is "off", load current is supplied by both $L_{I}$ and $C_{I}$ in parallel. If $L_{1}$ is made large enough, then the current in $L_{1}$ will change very little from the transistor on to off time and will be equal to the de output current $V_{0} / R_{L}$. When the transistor turns "on" again, diode $D_{1}$ is reverse biased and stops conducting. Load current is then supplied by the source through the transistor.

The series-switching converter behaves like a step-down transformer where the input source voltage $V_{i n}$ at an average current of $I_{1}\left(\frac{T_{0 n}}{T}\right)$ is transformed to a lower voltage $V_{0}=V_{\text {in }}\left(\frac{T_{\text {on }}}{T}\right)$ at a stepped up average current $I_{0}$. This, of course, is with transistor and diode losses neglected so input power equals output power.

The converter of Figure $6-7$ can be transformed into a voltage regulator by adding an output voltage sampling resistor network, a difference amplifier, a stable voltage reference, and a dc voltage controlled pulsewidth modulator. 
The negative feedback circuit changes the pulse width or duty cycle to maintain a constant output. Changes in the load or input voltage are compensated by varying the duty cycle of the transistor switch without increasing the interval power dissipated in the switching regulator.

Present practice is to switch at the $20 \mathrm{kHz}$ rate; however; the switching frequency may range from $3-100 \mathrm{kHz}$. The higher trequencies result in smaller filter inductors and capacitors which in turn reduces the size and weight of the regulator for the same power output. Higher frequencies also result in larger switching losses and hence lower efficiencies.

\section{STEP-UP SHUNT SWITCH CONVERTER/REGULATOR}

Unlike the step-down switching converter which can only produce a voltage less than the input voltage, the step-up switching converter is capable of producing a higher voltage than the input. It can be used wherever a higher voltage than the existing source is required. There is no $d c$ isolation, however, from the negative terminal of the source.

Figure 6-8A illustrates the basic step-up switching converter and its wave form. Transistor $Q_{1}$ is switched "on" and "off". It is "on" for $T_{\text {on }}$ and "off" for $T_{\text {off }}$ with a period $T$. Placing diode $D_{l}$, filter capacitor $C_{0}$, and load $R_{0}$ as shown, the output voltage can be stepped up to $v_{0}=\frac{v_{\text {in }}}{\left(\frac{1-T_{0 n}}{T}\right)}$ 


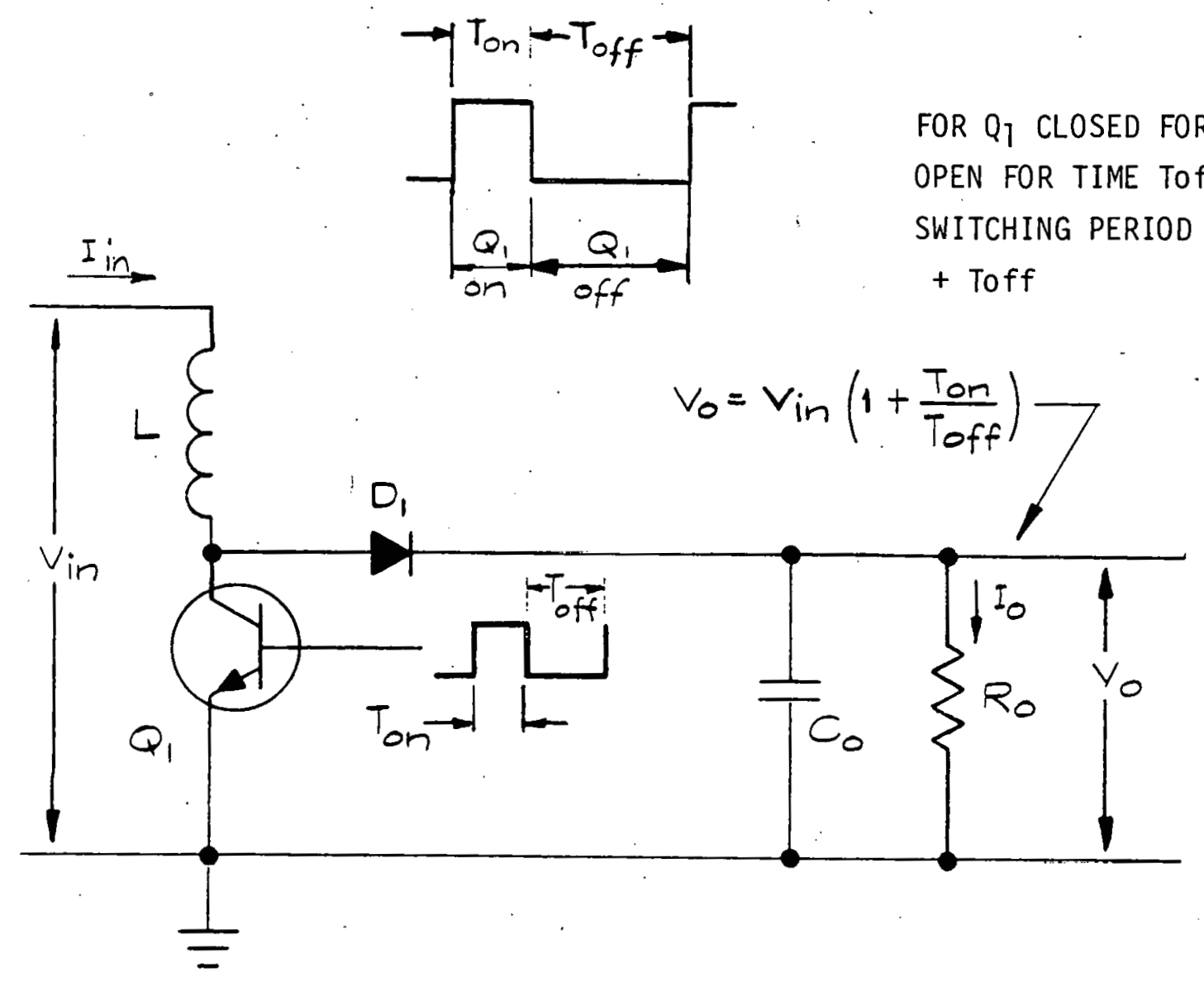

Figure 6-8A A Shunt Switch Voltage Step-Up Converter 
As transistor $Q_{1}$ is turned "on", energy from the source is stored in inductor $L$. Diode $D_{1}$ is reverse biased, and capacitor $C_{0}$ supplies the load current $I_{0}$, thereby partially depleting its stored energy $\left(1 / 2 C_{0} V_{0}{ }^{2}\right)$. When $Q_{1}$ turns "off", an inductive voltage step $\left(V_{0}-V_{i n}\right)$ is generated across inductor $L$, forcing the $Q_{1}$ side of diode inductor $L$ positive with respect to the input. This forward biased diode $D_{1}$ now trinsfers the current that had been flowing through inductor $L$ and transistor $Q_{1}$ to filter capacitor $C_{0}$ and load $R_{0}$.

When $Q_{1}$ is turned "off", the energy stored in inductor $L$ during $T_{0}$ $\left(1 / 2 \mathrm{LI}_{\text {peak }}^{2}\right)$ is transferred to load $R_{0}$ and filter capacitor $C_{0}$ to restore the energy lost while supplying load $R_{n}$ during $T_{o n}$.

The duty cycle $\frac{T_{\text {on }}}{T}$ controls the amplitude of the inductive voltage. As $T_{\text {on }}$ increases, more energy is stored in inductor L. Therefure, the inductive voltage pulse across inductor $L$ during $T_{\text {off }}$ must be higher if all the stured energy is to be transferred out during $T_{\text {off }}$.

Assuming no power losses during switching, the step-up converter acts like a step-up voltage transformer where the input voltage $V_{\text {in }}$, al a dc current $I_{i n}$, is stepped up to a higher voltage. 
By adding a negative feedback circuit consisting of a voltage sampling resistor network, a constant voltage reference, a difference amplifier, and a dc voltage-controlled, variable-width pulse generator, the step-up converter can be transformed into a voltage regulator. The basic circuit and its corresponding wave form is shown in Figure 6-8B.

From Figure $6-8 \mathrm{~B}$, it can be seen that the duty cycle $\frac{\mathrm{T}_{\text {on }}}{\mathrm{T}}$ is automatically adjusted to maintain a constant output voltage with variations in input voltage. As $V_{\text {in }}$ increases, the duty cycle decreases; conversely, a decrease in $V_{\text {in }}$ causes an increase in duty cycle. This circuit will also regulate changes in output load current in the same manner. 

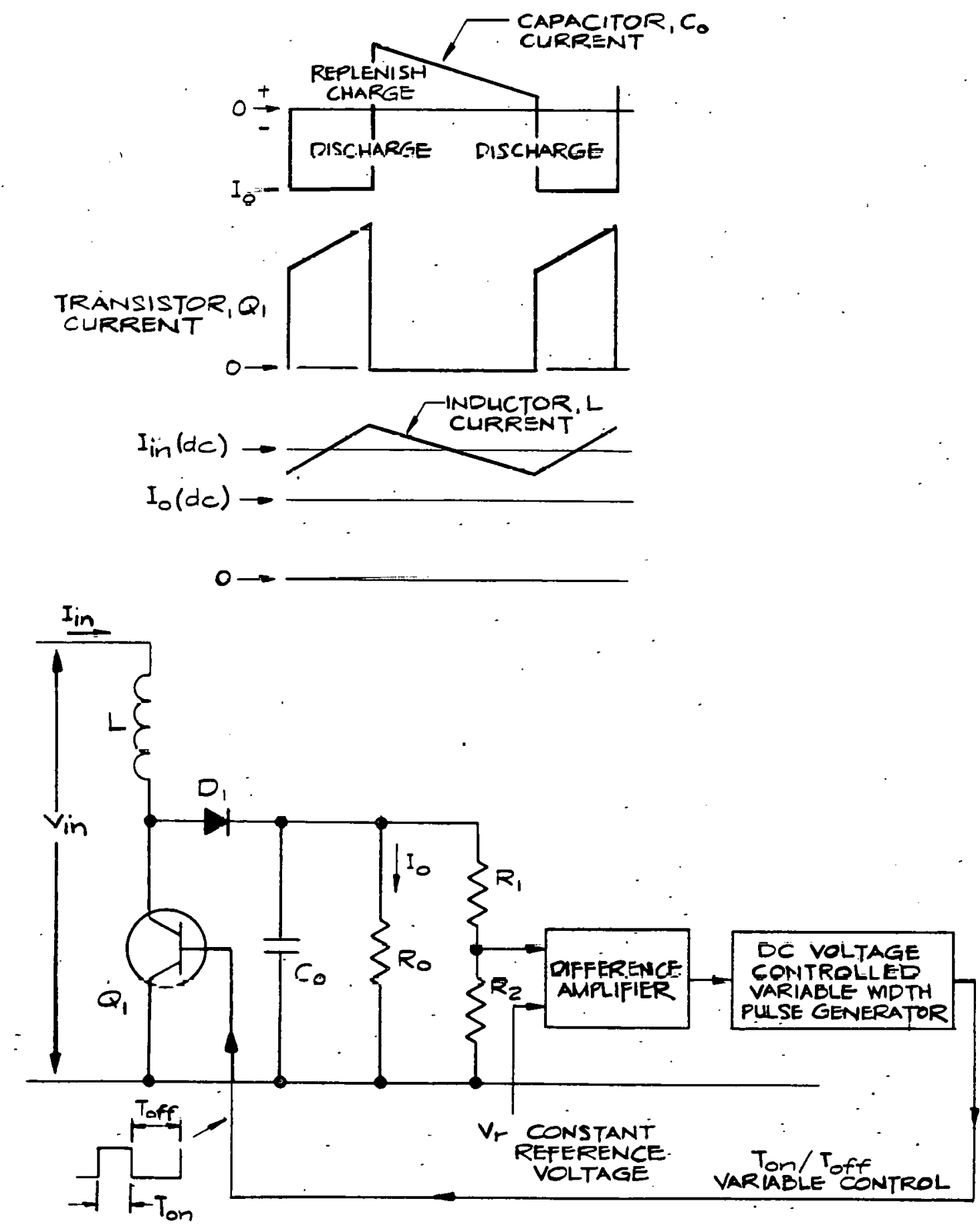

Figure 6-8B Addition of a Feedback Loop to Build a Step-Up Switching Converter ${ }^{6}$ (Courtesy of Hayrten Book Company, Inc.). 
COMPARISON OF VOLTAGE REGULATORS

Four different voltage regulators have been described. Each uses a different means of control and will exhibit unique advantages and disadvantages. In thịs section, a comparison of some of these characteristics will be made to aid the solar PV system designer in selecting the regulator best suited for his needs. Battery life is extended by using the proper charging profile and having adequate battery voĺtage temperature compensation. Each type regulator can accomplish this goal with appropriate control logic but may vary in degree of success. Comparisons are made therefore of each regulator under the headings "Reliability", "Control", "Heatsink", "Power Handling Capability", and "Cost". The switching type voltage regulators are also compared in terms of operation frequency, EMI problems and stability.

Finally, recommendations are made for the usage of each type in solar PV applications. 


\section{SERIES-PASS VOLTAGE REGULATCR}

Efficiency The series-pass element continuously dissipates power, making this type of regulator one of the least efficient. Regulator efficiency increases as the input voltage decreases, or as the output voltage increases according to:

$$
E=\frac{P_{\text {out }}}{P_{\text {out }}+P_{\text {reg }}}=\frac{V_{0} I_{0}}{V_{u} I_{u}+\left(V_{i n}-V_{0}\right) I_{u}}=\frac{V_{0}}{V_{\text {in }}}
$$

Maximum efficiency occurs when the pass transistor operates near saturation. Reliability Because of the low complexity of the circuit, a higher reliability can be attained than for other types of regulators.

Control Logic Control logic can be implemented for temperature compensation, charging control and low voltage protection. The control element can be operated anywhere from near saturation to "off". Heatsink Requirements A fairly large heatsink is required to dissipate all the power in the pass transistor, which contributes much to the weight and size of the regulator. If the heat dissipated by the regulator could somehow be recovered, then the size and weight could be reduced through use of a smaller heatsink.

Power Handling Limitations Switching transistors can be paralleled to handle larger loads up to 2000 watts, after which, unequal current sharing and base drive deficiencies become predominant 1 imiting factors. Cost The cost of the series-pass voltage regulator is relatively low. Cheap silicon transistors can be used. Darlington transistors, used as the pass element, are not recommended because of the larger voltage drop and resulting power loss. 
Recommended Use The series-pass voltage regulator can be used in high voltage systems because of $i$ ts increased efficiency at those levels.

Although it continuously dissipates power, the level of power dissipation is much less than the shunt voltage regulator, which dissipates almost all of the power when the battery capacity is reached. The series-pass voltage regulator can be used in the $1 \mathrm{kw}$ to $2 \mathrm{kw}$ power range, whereas the shunt regulator is only adequate to $1 \mathrm{kw}$. The series-pass regulator (rather than a switching regulator) can also be used where high reliability and lower cost are required, because of circuit simplicity. This type of regulator is more suited to battery storage systems requiring continuous float charging than a shunt regulator, for example, because less power would be dissipated by the voltage regulator during float.

\section{SHUNT VOLTAGE REGULATOR}

Efficiency The shunt regulator dissipates nearly all of the solar power when the battery approaches 100 percent capacity, and essentially none of the power when the battery capacity is low. This raises the overall daily effiriency of the shunt voltage regulator, because power will not be dissipated by the regulator until the battery nears 100 percent capacity. Therefore, minimum efficiency occurs when the battery reaches full charge.

Reliability The basic shunt voltage regulator circuitry is not complex, and therefore is relatively reliable. 
Control Logic Control logic can be implemented for temperature compensation, charging control, or low voltage alarms.

Heatsink Requirements The large power dissipation required during full charge requires a fairly large heatsink.

Power Handling Limitations Power handling transistors can be paralleled to attain higher power levels; however, unequal current sharing between transistors and large base drives becomes a problem beyond 800 to 900 watts. Cost The cost of the shunt voltage regulator is relatively low. Cheap silicon power transistors and power Darlington transistors can be used as the control element.

Recommended Use The shunt regulator is limited to systems of 1000 watts or less because of the problem of paralleling many power transistors. In this power range, the shunt regulator is rather well suited for medium to deep discharge battery storage systems because of $i$ ts near 100 percent efficiency when the battery is less than full capacity. It would not be recommended for battery backup systems where the batteries would be float charged 100 percent of the time, to compensate for the battery stand loss (the regulator would be very inefficient). The shunt regulator is limited in system battery voltage to $48-60$ volt dc. Beyond that, the breakdown voltages of the power transistor could be exceeded, accompanied by the destruction of the transistor. The shunt regulator is also low in cost and has better reliability than, for example, the switching regulator. 


\section{STEP-DOWN SERIES SWITCH REGULATOR}

Efficiency The efficiency of the series switch regulator varies from 70 to 97 percent, with the value dependent upon the ac and dc losses in the switching transistor and diode. The efficiency can be approximated by $\frac{V_{0}}{V_{0}+2}$ where 2 represents the combined $d c$ and ac voltage drops. The efficiency increases with an increase in output voltage.

Reliability Because of the complexity of the circuitry, it is less reliable than the series-pass or shunt voltage regulators. Control Logic Control logic can be implemented for temperature compensation, charging control, low voltage protection and maximizing array power.

Heatsink Requirements The high efficiency of the circuitry means that a smaller heatsink may be used.

Power Handling Limitations The step-down vol tage regulator provides regulation for systems between 1000 and 15,000 watts.

Cost The cost of this type of regulator is much higher than the cost of the series-pass or shunt voltage regulators, because of the complexity of the circuitry. It can use low cost silicon power transistors with the appropriate drive circuitry at lower frequencies, but at higher frequencies, it is necessary to use faster silicon power transistors or the more expensive power FET transistors, which use a greatly simplified drive circuit.

Frequency Operation. Operation is possible at frequencies between $5 \mathrm{kHz}$ and $1.00 \mathrm{kHz}$, wi th the most typical application at $20 \mathrm{kHz}$. At this frequency, the size of the inductor and output filter capacitor can be reduced, which 
will enable the reduction of the overall size and weight of the voltage regulator.

EMI Problems There are numerous EMI problems associated with a switching regulator, such as environmental contamination and the problem of internal noise and crosstalk which can affect proper regulator operation. Stability since the switching regulator is a negative impedance with regard to the PV array, and since the maximum power point of the array can vary, the regulator must be designed to be stable under its intended operating range. Otherwise, it will tend to oscillate.

Recommended Use The step-down regulator is better suited for systems of 1000-15,000 watts, with emphasis on the larger systems. Because of its high efficiency, it can handle the higher power that the series-pass and shunt requlators cannot. It should he used where system efficicncy is of prime concern, since efficiencies of 98 percent can be attained with proper design. It is also better suited to higher voltage systems since efficiency increases with output voltage.

\section{STEP-UP SHUNT SWITCHING REGULATOR}

Efticiency the efficiency of the step-up regulator can vary from 70 percent to 95 percent, depending on the $\mathrm{dc}$ and ac losses in the switching transistor and diode. The efficiency is limited by the input voltage $\left(V_{i n}\right)$ according to $\frac{V_{\text {in }}}{V_{\text {in }}+2}$ and is usually from 1 to 5 percent less than the step-down regulator. 
Reliability The reliability is less than the series-pass or the shunt voltage regulator due to the overall circuit complexity.

Heatsink Requirements The generally high efficiency of this voltage regulator permits the use of smaller heatsinks than either the seriespass or shunt voltage regulators.

Power Handling Limitations Because of the high input current and power transistor limitations, it would be economically impractical to consider this type of regulator for power levels greater than $1 \mathrm{kw}$. Cost Because of the complexity of the circuitry, the cost of this regulator is high. Cheap silicon power transistors with the appropriate drive circuitry or the more expensive power FET transistors with their simplified drive circuitry requirements can be used as the switching element.

Frequency 0peration The operating frequency of the step-up regulator can vary from $5 \mathrm{Khz}$ to $100 \mathrm{kHz}$, but $20 \mathrm{kHz}$ is usually typical. Operating the device at higher frequencies reduces the size of both the inductor and output filter capacitor. Since these components are the largest in the regulator, a reduction in their size means a big reduction in the size and weight of the device.

EMI Problems The step-up voltage regulator generates lower EMI levels than the step-down voltage regulator.

Stability Since the switching regulator is a negative impedance with respect to the PV array, and since the maximum power point of the array can vary, the regulator must be designed to be stable under its entire operating range. Otherwise, it will tend to oscillate. 
Recommended Use Recommended use of the step-up regulator is similar to that for the step-down regulator except that $i$ ts efficiency is 1 to 5 percent less, and it will generate less EMI.

\section{COST/PERFORMANCE TRADE-OFFS}

A comparison of the four types of voltage regulators, showing lhe normalized cost to performance trade-offs, is provided in Table 6-5. The ratings are based upon a current price schedule and the complexity which the designer includes in the intended system. The efficiency was calculated with respect to a 14 volt dc output voltage.

With the cost of each regulator having been determined on a relative basis, the actual cost of a commercially available shunt regulator system can be applied, giving an approximate indication of the cost of each type of regulator.

It is not possible to cost each regulator component on an individual basis because of the price differentials involved between components on a quantity and quality basis, and the variations in designs. 
TABLE 6-1 - NORMALIZED COST/PERFORMANCE TRADE-OFFS

\begin{tabular}{|c|c|c|c|c|}
\hline & $\begin{array}{l}\text { STEP-DOWN } \\
\text { REGULATOR }\end{array}$ & $\begin{array}{c}\text { STEP-UP } \\
\text { REGULATOR }\end{array}$ & $\begin{array}{l}\text { SERIES-PASS } \\
\text { REGULATOR }\end{array}$ & $\begin{array}{c}\text { SHUNT } \\
\text { REGULATOR }\end{array}$ \\
\hline EFFICIENCY (\%) & 1.0 & 0.95 & 0.67 & 0.67 \\
\hline POWER DENSITY & $0.25-1.0$ & $0.25-0.90$ & 0.25 & 0.25 \\
\hline $\operatorname{cost}$ & 2.5 & 2.5 & 1.0 & 1.0 \\
\hline REL IAB IL ITY & 0.7 & 0.7 & 1.0 & 1.0 \\
\hline COMPLEXITY & 3.3 & 3.3 & 1.0 & 1.0 \\
\hline SIZE & 1.0 & 1.3 & 3.3 & 3.3 \\
\hline WEIGHT & 1.0 & 1.0 & 5.0 & 5.0 \\
\hline
\end{tabular}




\section{REFERENCES}

Figure Number

$6-1^{1}$

$f-r^{?}$

$6-4^{3}$

$6-6^{4}$

$6-7^{5}$

$6-8 B^{6}$
Title

Texas Instruments, Inc., "The Voltage Regulator Handbook," 1977.

Texas Instrumentş, InG, , "The Voltagr. Rrgulnton llundhonok, ," 1977.

Pressman, A. K., "Switching and Linear Power Supply, Power Converter Design," Hayden Book Company, Inc., 1977.

Texas Instruments, Inc., "The Voltage Regulator Handbook," 1977.

Pressman, A. K., "Switching and Linear Power Supply, Power Converter Design," Hayden Book Company, Inc., 1977.

Pressman. A. K. , "Swit.ching and Linear Power Supply, Power Converter Design," Hayden Book Company. Inc., 1977. 


\section{CHAPTER 7 \\ SELECTION OF BATTERIES FOR PHOTOVOLTAIC SYSTEMS}

- Shallow Cycle Service

- Deep Cycle Service

- Standby Service Versus Cycle Service

- Application Data Summary Form

Work Performed for

The U.S. Department of Energy

Sandia National Laboratories

Albuquerque, New Mexico 87185

Under Contract No. 13-2202 


\section{CHAPTER 7 SELECTION OF BATTERY FOR PHOTOVOLTAIC SYSTEM}

Solar photovoltaic system designers should work closely with the sales and application engineers of representative battery manufacturers to make a wise selection of the battery type for the storage sub-system. These discussions can be most rewarding when each party has a summary of the subsystem requirements. A form useful for this purpose is given at the end of this chapter.

Photovoltaic systems can require batteries with a wide range of capabilities. Classifications of service requirements can help identify the optimum battery type for each application. The following classifications are helpful:

\section{A. Shallow Cycle Service}

Most cycles are less than $20 \%$ depth, but a small number may be as deep as 50 percent of 5 -hour rated $25^{\circ} \mathrm{C}$ capacity.

B. Deep Cycle Service

Most cycles are in the range of $60-80 \%$, but an occasional cycle may be $100 \%$ of rated $5-h 25^{\circ} \mathrm{C}$ capacity. 


\section{Standby Service versus Cycle Service \\ Standby service ranges from 2-12 cycles per year with the remaining service time on float at a predetermined voltage at ambient temperature.}

Deep or shallow cycle service is repetitive cycling on a fairly predictable regime with as many as 200-500 cycles per year and 1=2

- eycles jur ldy.

Combinations of the above classifications are common in photovoltaic system service:

I. Shallow Cycle-Standby (few shallow cycles, mainly float)

II. Shallow Cycle-Deep Cycle - Float-Stand (float occurs after shallow sycles and high insolation periuds whtle discharge stand occurs during long black-outs).

III. Deep Cycle-Standby (few deep cycles, mainly float)

IV. Deep rycie - Little Float (prodominantly deep cycling)

Pure lead dnd lead-calcium type lead-acid batteries are normally recommended for service types I and III above. Life may vary from 2-3 years in the case of thin plates, 6-10 years with medium thickness plates and 17-22 years with plates of $0.25-0.35$ inch thickness.: These cells are usually assembled with an effective microporous separator but with a minimum retainer system. 
When an effective retainer system is added to the pure lead or lead-calcium cells, then the cells can be placed in deep cycle service category type IV - al though the service life will be only moderate compared to the cycle life of a lead-antimony cell of the same capacity.

Pasted plate lead-antimony cell designs with thick plates $(0.25-$ 0.35 inches), effective microporous separators and proper active material retainers give excellent life on deep cycle regimes. When higher ampere rates are required, the number of plates is increased, plate thickness is decreased, and service life is reduced.

The tubular positive battery also gives excellent life on deep discharge cycle service. In addition, the tubular positive plate design increases effective plate area and gives very good high current rate performance.

Maintenance (addition of water to celîs) will be greater in leadantimony cells than in lead-calcium cells unless the reserve acid in each cell is increased in the cell design used for solar applications where low maintenance is known to be an important requirement. 
Category II service requires a lead-antimony battery because of the variety of service conditions and the possibility of very deep discharges followed by discharged stands.

Requirements for low maintenance can be met by a pure lead battery provided the charge - discharge rates are very low and with in the range of the thick platc, chargc retaining, purc lcad ccll designa. These cells can be occasionally deep discharged and then restored to full capacity by a low rate ( $75 \mathrm{~h}$ minimum) recharge.

Lead-calcium batteries wi th oxygen-hydrogen recombination devices in their vents are excellent for low maintenance applications, but their deep cycle life is more limited at today's state-of-the-art than leadantimony cells.

A reliable automatic watering accessory which enables a leadantimony battery to meet the low maintenance requirement is becoming a viable alternative for the solar PV system designer to consider.

A collection of additional data on the various types of lead-acid batteries and on the pocket-plate nickel-cadmium battery is given in the appendix as an aid to the system designer in selecting the battery type and size most suitable to each appicication specification. 
To assist the battery manufacturer's applications engineer in assessing application requirements, it is recommended that the application data form be completed and submitted along with any request for technical information or pricing made to a manufacturer by the solar system engineer. 


\section{APPLICATION DATA SUMMARY FORM \\ Solar Photovoltaic Battery Subsystem}

1. Array vs. Load Power Estimates

\begin{tabular}{|c|c|c|c|}
\hline $\begin{array}{l}\text { Month } \\
\text { of Year }\end{array}$ & $\begin{array}{l}\text { Max. Array } \\
\text { Power - kW }\end{array}$ & $\begin{array}{l}\text { Useful Array } \\
\text { Power - kW }\end{array}$ & $\begin{array}{l}\text { Total Loac } \\
\text { Power - kl }\end{array}$ \\
\hline \multicolumn{4}{|l|}{ Jan. } \\
\hline \multicolumn{4}{|l|}{ Feb. } \\
\hline \multicolumn{4}{|l|}{ Mar. } \\
\hline \multicolumn{4}{|l|}{ Apr. } \\
\hline \multicolumn{4}{|l|}{ May } \\
\hline \multicolumn{4}{|l|}{ June } \\
\hline \multicolumn{4}{|l|}{ Juty } \\
\hline \multicolumn{4}{|l|}{ Aug. } \\
\hline \multicolumn{4}{|l|}{ Sept. } \\
\hline \multicolumn{4}{|l|}{ Oct. } \\
\hline \multicolumn{4}{|l|}{ Nov. } \\
\hline \multicolumn{4}{|l|}{ Dec. } \\
\hline \multicolumn{4}{|c|}{$\begin{array}{l}\text { Estilld led Annual } \\
\text { Energy - kWh }\end{array}$} \\
\hline \multicolumn{4}{|c|}{ - Array Output } \\
\hline
\end{tabular}

2. Standby Battery Charging Equipment

2.1 Power Source: (check) ac grid ; diesel electric

2.2 Power Rating: generator

2.3 Current Rating:

2.4 Type Regulation: (check one)

2.4.1 Constant Current Type

2.4.2 Constant Potential Type

2.4.3 Modified Constant Potential Type

2.4.4 0ther

Describe: 
3. Photovoltaic Array Power Characteristics

3.1 Voltage; minimum volts maximum volts

3.2 Current for charging battery; maximum amperes

3. 3 Power; minimum kW maximum $\mathrm{kW}$

3.4 Power profile; average $\mathrm{kW}$ each month during year

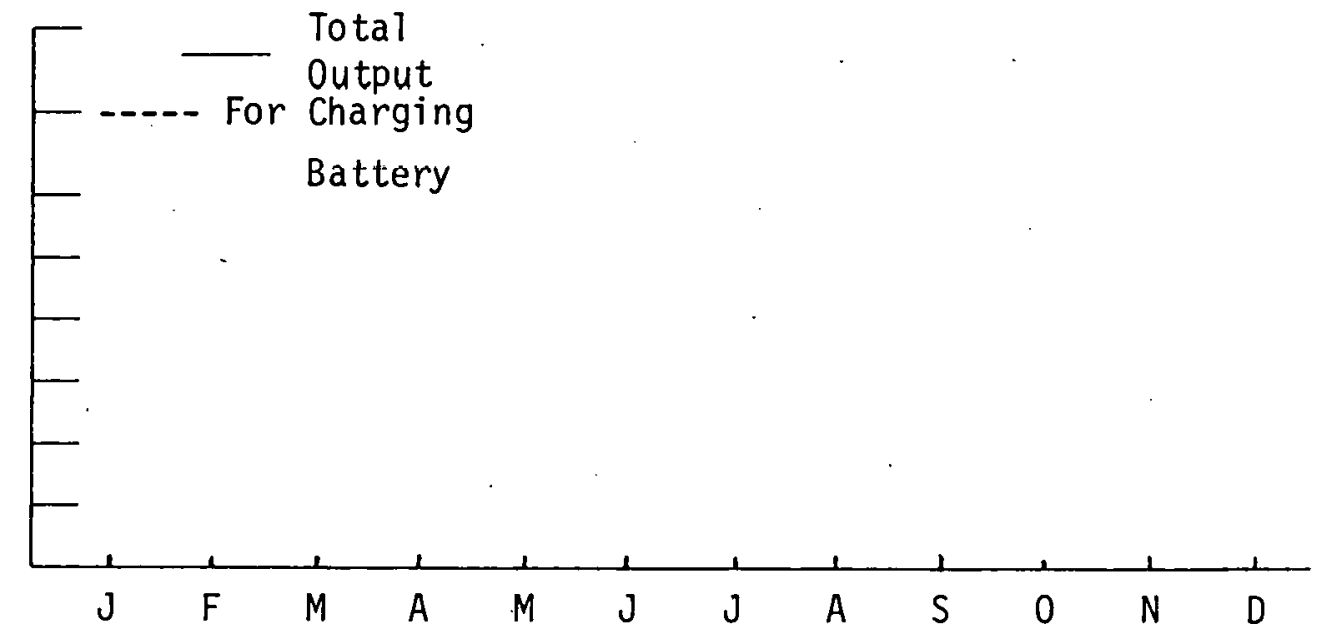

3.5 Expected daily power output:- Total --- For charging battery

Maximum Power Output $\mathrm{kW}$

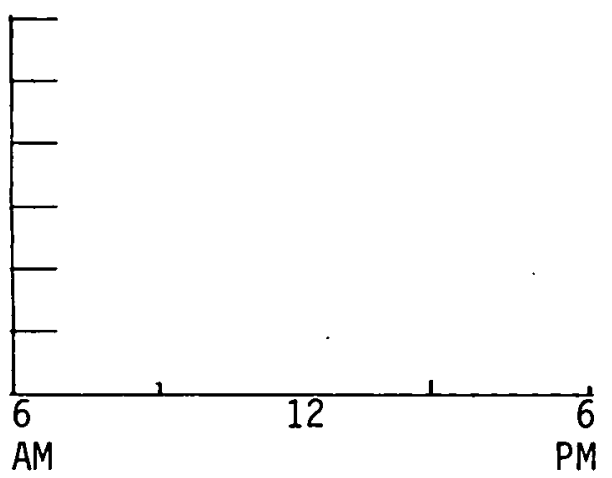

Minimum Power Output $\mathrm{kW}$

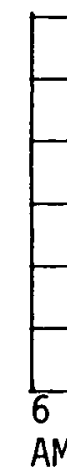

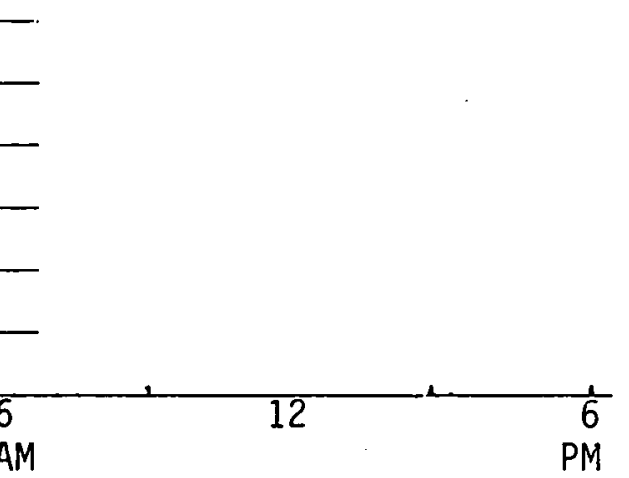


3.5.1 Expected zero power time per day: minimum hours

3:5.2 Maximum zero insolation period expected:

hours ; number periods per year

4. System and Equipment Loads on Battery

4.1 System voltage window:

Minimum, bottom of discharge volts

Maximum, top-of-charge volts

4.2 Maximum Discharge current A

4.3 Battery energy storage requirement kWh

4.4 Typical and worst case battery daily load profile: KW versus time Typical Worst Case
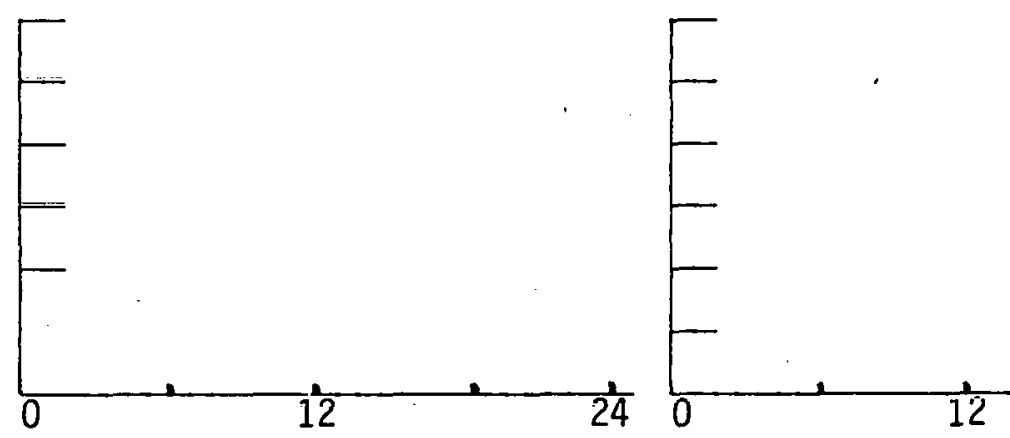
24 
4.5 Type of Equipment Loads on Batteries

Test

Unit

1 Appliance

(1)

(2)

(3) Total

4.5.1 Load

watts

4.5.2 Current, mean

4.5.3 Duration

4.5.4 Number per

A
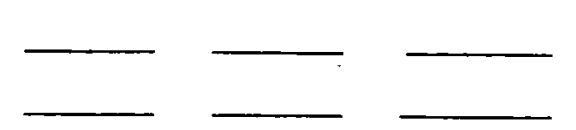

h day

ea

4.5.5 Number per ea week

4.5.6 Number per ea year

4.5.7 Average energy output per day kWh

4.5.8 Total energy output per year

kWh

4.5.9 Total energy input needed per year

kWh

5. Environmental Requirements

5.1 Temperature extremes: minimum maximum ${ }^{\circ} \mathrm{C}$ ${ }^{\circ} \mathrm{C}$

5.2 Desired battery life, years

5.3 Vibration and shock:

6. Maintenance Schedule Permitted:

Water addition every months. 
7. Space Allocations and Ventilation

7.1 Battery Space and Battery Room Dimensions

\begin{tabular}{|c|c|c|}
\hline Dimension & Battery Space & Battery Room \\
\hline Floor Area: & $f t^{2}$ & \\
\hline Dimensions: & & \\
\hline$L$ & $r l$ & $-\ldots-$ \\
\hline w & $\mathrm{ft}$ & 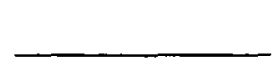 \\
\hline$H$ & $f t$ & \\
\hline Vol ume & $-\mathrm{ft}^{3}$ & \\
\hline
\end{tabular}

8. Other Information: 


\section{APPENDIX A}

\section{TYPICAL PERFORMANCE CHARACTERISTICS OF LEAD-ACID CELLS AND BATTERIES}

Work Performed for

The U.S. Department of Energy Sandia National Laboratories Albuquerque. New Mexico 87185 Under Contract No. 13-2202 


\section{APPENDIX A \\ TYPICAL PERFORMANCE CHARACTERISTICS OF LEAD-ACID \\ BATTERIES AND CELLS}

Representative data is summarized in the following appendices giving discharge and cycle life characteristics of cells and modules of the four major lead-acid battery types: pure lead flat plate, lead-calcium flat plate, lead-antimony flat plate and tubular positive lead-antimony.

Data is given for these parameters:

- Discharge voltage vs depth of discharge

- Energy output and energy density per unit weight and volume at $25^{\circ} \mathrm{C}$ with estimates for $0^{\circ} \mathrm{C}$ and $-18^{\circ} \mathrm{C}$.

- Wet life and estimated cycle life vs depth of discharge on cycling regimes.

This data is calculated from manufacturer's specification sheets, observed in laboratory tests on small samples of cells, or estimated from the performance of similar cells tested under the same conditions. 


\section{APPENDIX A-I \\ PURE LEAD CHARGE RETAINING BATTERIES \\ $(110-600 \mathrm{Ah})$}

Figure A-1-1 Discharge Voltage vs Percent Time to End Voltage,

11 to 500 Hour Discharge Rate, 110, 220, and $600 \mathrm{Ah}$

Cells, 1.300 Specific Gravity, $25^{\circ} \mathrm{C}$.

Figure A-1-2 Energy Density per Unit Weight, Charge Retaining 110, 220 and 600 Ah Cells vs Discharge Rate, 10-500 h, $25^{\circ} \mathrm{C}$.

Figure A-1-3 Energy Density per Unit Volume, Charge Retaining 110, 220 and 600 Ah Cells vs Discharge Rate, 10-500 h, $25^{\circ} \mathrm{C}$.

Table A-1-1 Discharge Energy Output vs Discharge Rate, 600 Ah Low Rate Charge Retaining Cel1, $25^{\circ} \mathrm{C}$. 


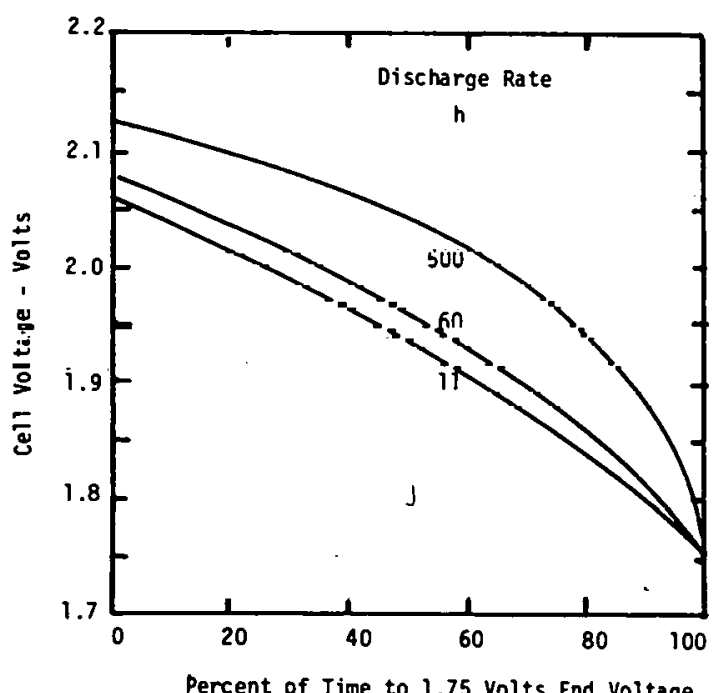

Figure $A-1-1$ Discharge Voltage vs. Discharge Rate, 11-500 Hours, Low Rate 110,220 and 600 Ah Charge Retaining Pure Lead Cells, 1.300 specific Gravity, $25^{\circ} \mathrm{C}$.

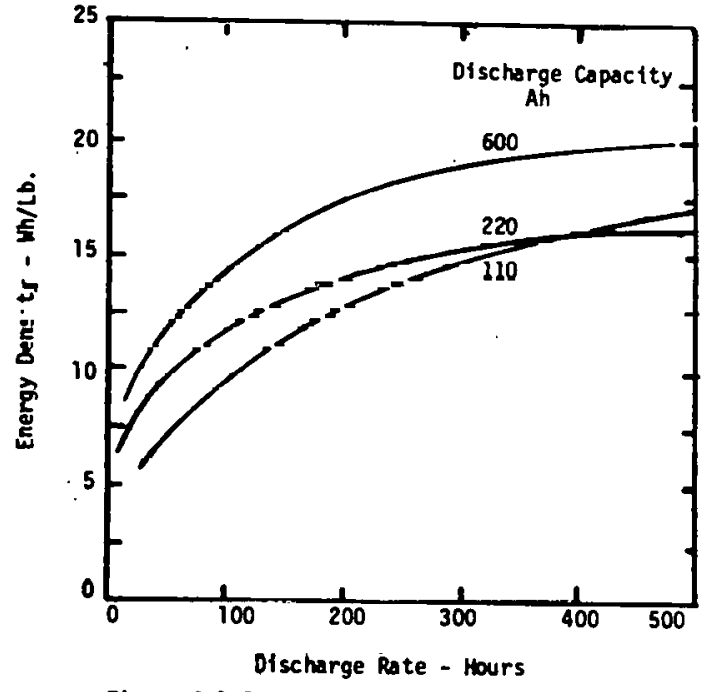

Figure A-1-2 Energy Density per Unit Weight vs Discharge Rate, 11-500 Hours, Low Rate Charge Retaining Pure Lead Cells. $110-600 \mathrm{Ah}, 1.300$ Specific Gravity, $25^{\circ} \mathrm{C}$.

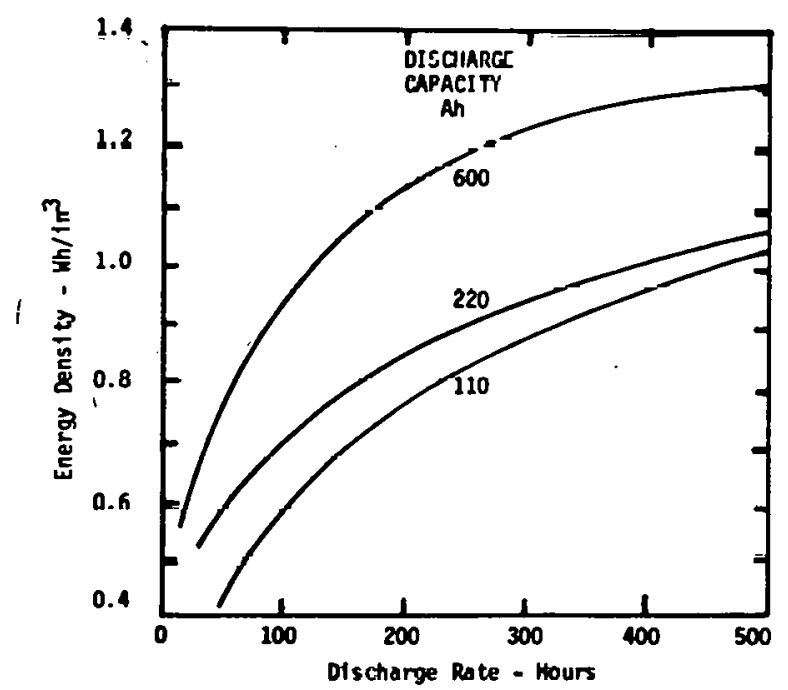

Figure A-1-3 Energy Density per Unit Volume vs Discharge Rate, 11 to 500 Hour Rate, Low Rate Charge Rotaining Pure Lead Cells, 110-600 Ah, 1.300 specific Gravity, $25^{\circ} \mathrm{C}$. 


\section{TABLE $A-1-1$}

Discharge Energy Output vs Discharge Rate 600 Ah Low Rate Charge Retaining Cell, $25^{\circ} \mathrm{C}$

\begin{tabular}{cccccc}
\hline \multicolumn{2}{c}{ Discharge } & $\begin{array}{c}\text { Capacity } \\
\text { Time }\end{array}$ & $\begin{array}{c}\text { Energy } \\
\text { Cutput } \\
\text { to } 1.8 \mathrm{~V}\end{array}$ & Energy Density to $1.8 \mathrm{~V}$ \\
$\mathrm{~h}$ & $\mathrm{~A}$ & Ah & Wh & Wh/1b & Wh/in \\
& & & & & \\
600 & 1.0 & 600 & 1210 & 21 & 1.38 \\
160 & 3.0 & 480 & 960 & 17 & 1.09 \\
80 & 5.0 & 400 & 780 & 13 & .88 \\
50 & 7.0 & 350 & 680 & 12 & .77 \\
30 & 10.0 & 300 & 580 & 10 & .66 \\
\hline
\end{tabular}

Cell Dimensions, inches:

$\begin{array}{cc}H & 14.0 \\ L & 7.6 \\ W & 8.3 \\ \text { Volume: } & 880 \mathrm{in}^{3} \\ \text { Weight: } & 58 \mathrm{ibs} .\end{array}$

Note: Charged and maintained in accord with manufacturer's operating instructions. 


\section{APPENDIX A-2 \\ LEAD-CALCIUM PASTED FLAT PLATE CELLS $(50-200 \mathrm{Ah})$}

Table A-2-1 Energy Output, Energy Density at 25,0 and $-18^{\circ} \mathrm{C}$ of 50,100 and 200 Ah Cells at the 1, 3, 8 and 500 Hour Discharge Rate.

Figure A-2-1 Cell Voltage vs Percent Time to Final Voltage of 50-200 Ah Cells at $25^{\circ} \mathrm{C}, 1.215$ Specific Gravity Sulfuric Acid.

Figure A-2-2 Energy Density per Unit Weight vs Discharge Rate (Hours) at $25^{\circ} \mathrm{C}, 50-200$ Ah Cells, 1.215 Specific Gravity Acid.

Figure A-2-3 Energy Density per Unit Volume vs Discharge Rate (Hours) at $25^{\circ} \mathrm{C}, 50-200$ Ah Cel1s, 1.215 Specific Gravity Acid. 
TABLE A-2-1

Energy Density vs Discharge Rate and Operating Temperature Lead-Calcium Flat Plate Cells

50-200 Ah

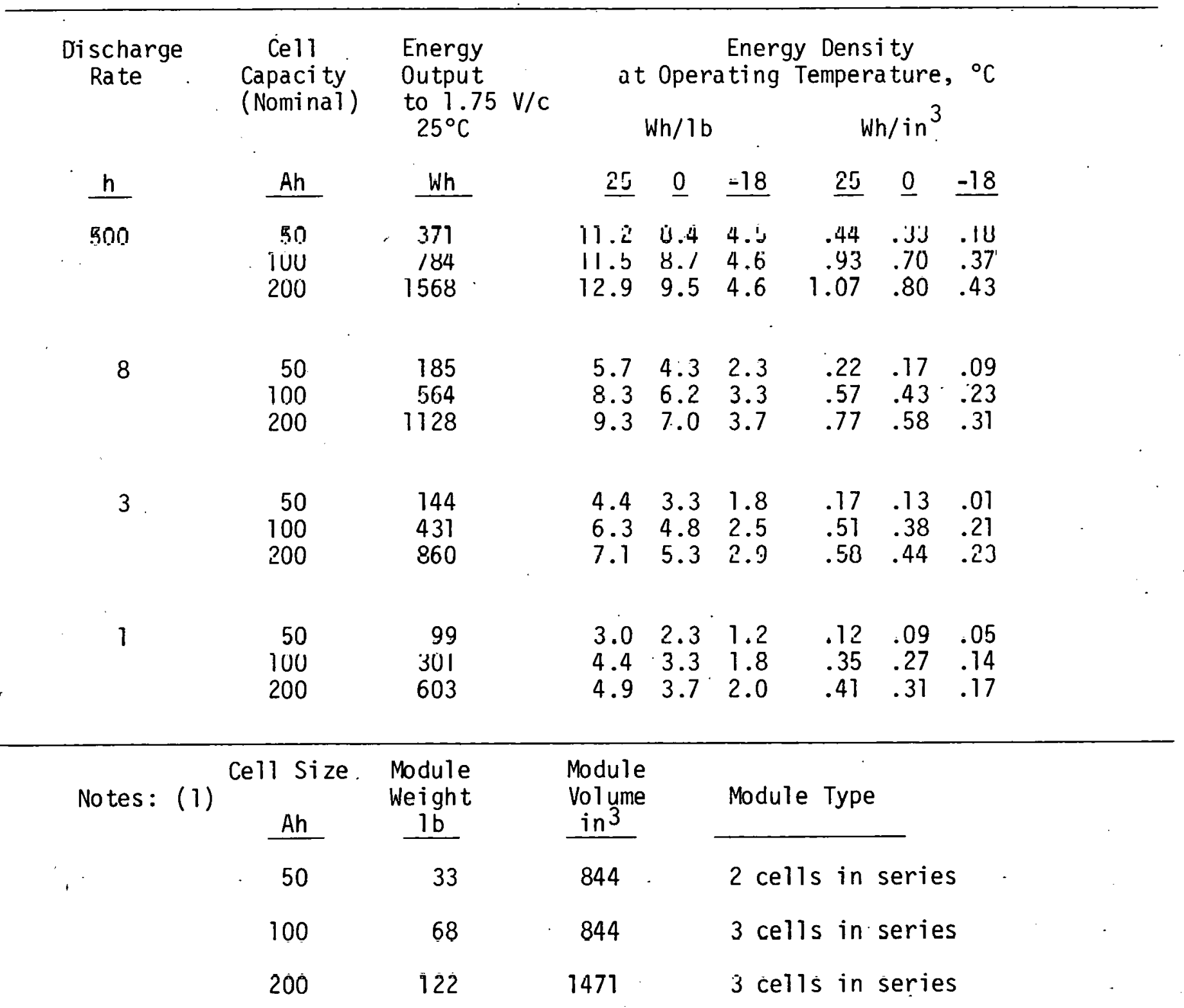

(2) Charged and maintained in accord wi.th manufacturer's operating instructions: 

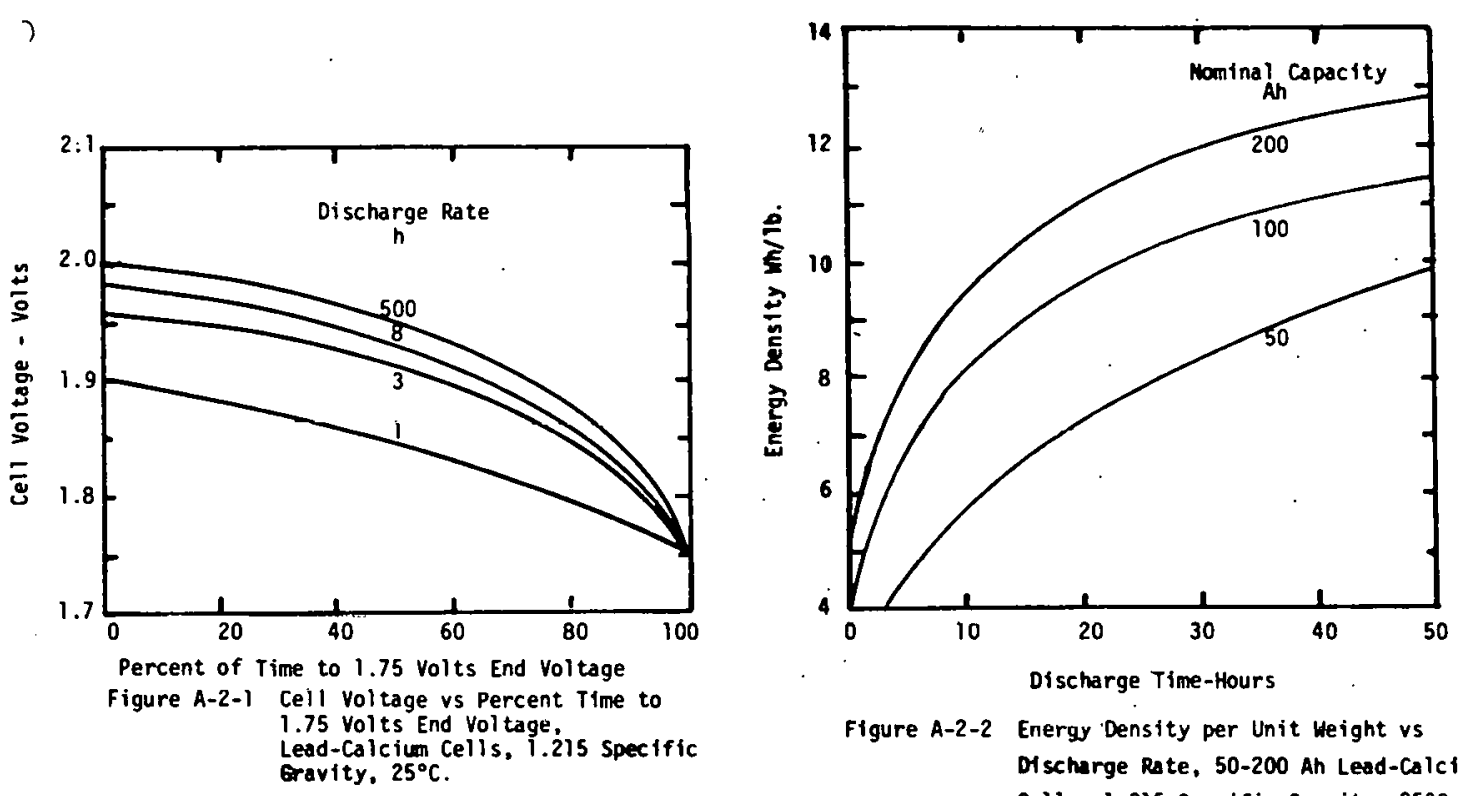

Figure A-2-2 Energy Density per Unit Weight vs D1 scharge Rate, 50-200 Ah Lead-Calcium Cells, 1.215 Specific Gravity, $25^{\circ} \mathrm{C}$.

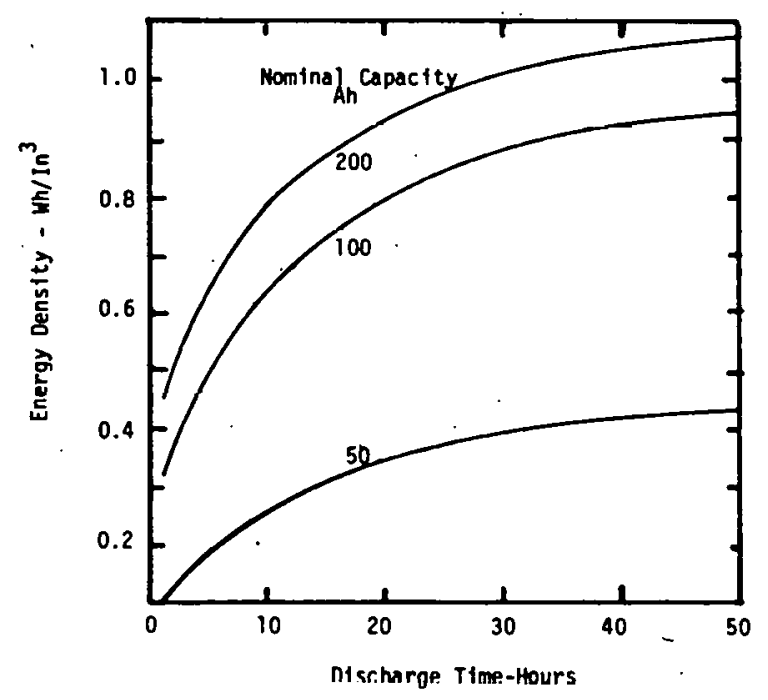

Figure A-2-3 Energy Density per Unit Volume vis Discharge Rate. 50-200 Ah Lead-calctum cells, 1.215 Spactfic Gravity, $25^{\circ} \mathrm{C}$. 


\section{APPENDIX $A-3$}

\section{LEAD-CALCIUM PASTED FLAT PLATE CELLS $(1850-3700 \mathrm{Ah})$}

Table A-3-1 Energy Output and Energy Density vs Discharge Rate, $1,3,8$ and 500 Hours at $-18,0$ and $25^{\circ} \mathrm{C}$.

Figure A-3-1 Discharge Cell Voltage vs Percent of Time to 1.75 Volts End Vol tage, 1, 3, 8 and 500. Hour Discharge Rate, $25^{\circ} \mathrm{C}$.

Figure A-3-2 Energy Density per Unit Weight vs Discharge Rate, 1-500 Hours, $25^{\circ} \mathrm{C}$.

Figure A-3-3 Energy Density per Unit Volume vs Discharge Rate, 1-500 Hours, $25^{\circ} \mathrm{C}$. 
TABLE $\cdot A-3-1$

Energy Density vs Discharge Rate and Operating Temperature Lead-Calcium Flat Plate Cells

(1020-3700 Ah)

\begin{tabular}{|c|c|c|c|c|c|c|c|c|c|}
\hline \multirow{2}{*}{$\begin{array}{c}\text { Discharge } \\
\text { Rate } \\
\text { h }\end{array}$} & \multirow{2}{*}{$\begin{array}{c}\text { Cell } \\
\text { Capacity } \\
\text { (Rated 8-h) } \\
\begin{array}{c}\text { Alı } \\
(8-h)\end{array}\end{array}$} & \multirow{2}{*}{$\begin{array}{c}\text { Energy } \\
\text { Output } \\
\text { to } 7.75 \\
25^{\circ} \mathrm{C} \\
\text { Wh } \\
\left(25^{\prime \prime}(\mathrm{i})\right.\end{array}$} & \multirow{2}{*}{$\mathrm{V} / \mathrm{C}$} & \multicolumn{6}{|c|}{$\begin{array}{c}\text { Energy Density } \\
\text { at Operating Temperature, }{ }^{\circ} \mathrm{C} \\
\text { Wh/1b }, \quad \text { Wh/ in }{ }^{3}\end{array}$} \\
\hline & & & & 25 & 0 & -18 & 25 & 0 & -10 \\
\hline 500 & $\begin{array}{l}1020 \\
1850 \\
2530 \\
3150 \\
3700\end{array}$ & $\begin{array}{l}5472 \\
5350 \\
7086 \\
8345 \\
9300\end{array}$ & & $\begin{array}{l}13.6 \\
14.0 \\
13.6 \\
13.9 \\
13.4\end{array}$ & $\begin{array}{l}10.2 \\
10.5 \\
10.2 \\
10.4 \\
10.1\end{array}$ & $\begin{array}{l}5.4 \\
5.6 \\
5.4 \\
5.5 \\
5.4\end{array}$ & $\begin{array}{l}1.11 \\
1.08 \\
1.07 \\
1.26 \\
1.41\end{array}$ & $\begin{array}{r}.83 \\
.81 \\
.81 \\
.95 \\
1.05\end{array}$ & $\begin{array}{l}.45 \\
.43 \\
.43 \\
.50 \\
.56\end{array}$ \\
\hline 8 & $\begin{array}{l}1020 \\
1850 \\
2530 \\
3150 \\
3700\end{array}$ & $\begin{array}{l}3667 \\
3490 \\
4780 \\
5900 \\
6990\end{array}$ & & $\begin{array}{r}9.1 \\
9.2 \\
9.2 \\
9.9 \\
10.1\end{array}$ & & & $\begin{array}{r}.75 \\
.71 \\
.72 \\
.90 \\
1.06\end{array}$ & & \\
\hline 3 & $\begin{array}{l}1020 \\
1850 \\
2530 \\
3150 \\
3700\end{array}$ & $\begin{array}{l}2680 \\
2460 \\
3515 \\
4340 \\
5190\end{array}$ & & $\begin{array}{l}6.7 \\
6.4 \\
6.8 \\
7.3 \\
7.6\end{array}$ & $\begin{array}{l}5.0 \\
4.8 \\
5.1 \\
5.4 \\
5.6\end{array}$ & $\begin{array}{l}2.7 \\
2.6 \\
2.7 \\
2.9 \\
3.0\end{array}$ & $\begin{array}{l}.54 \\
.50 \\
.53 \\
.66 \\
.78\end{array}$ & $\begin{array}{l}.41 \\
.37 \\
.40 \\
.49 \\
.59\end{array}$ & $\begin{array}{l}.31 \\
.19 \\
.21 \\
.26 \\
.32\end{array}$ \\
\hline 1 & $\begin{array}{l}1020 \\
1850 \\
2530 \\
3150 \\
3700\end{array}$ & $\begin{array}{l}1567 \\
1385 \\
2080 \\
2625 \\
3113\end{array}$ & & $\begin{array}{l}2.0 \\
3.6 \\
4.0 \\
4.3 \\
1.5\end{array}$ & $\begin{array}{l}1.5 \\
2.7 \\
3.0 \\
3.3 \\
3.4\end{array}$ & $\begin{array}{l}.8 \\
1.5 \\
1.6 \\
1.8 \\
1.8\end{array}$ & $\begin{array}{l}.16 \\
.28 \\
.32 \\
.41 \\
.47\end{array}$ & $\begin{array}{l}.12 \\
.21 \\
.24 \\
.30 \\
.35\end{array}$ & $\begin{array}{l}.05 \\
.11 \\
.13 \\
.16 \\
.19\end{array}$ \\
\hline
\end{tabular}

Notes: (1) Cell size Weight Volume

\begin{tabular}{|c|c|c|}
\hline Ah & $1 b$ & in $^{3}$ \\
\hline $\begin{array}{l}1020 \\
1850 \\
2530 \\
3150 \\
3700\end{array}$ & $\begin{array}{l}402 \\
382 \\
520 \\
601 \\
693\end{array}$ & $\begin{array}{l}4943 \\
4943 \\
6621 \\
6621 \\
6621\end{array}$ \\
\hline
\end{tabular}

Battery

Type

2 cells in one jar single cell

$\begin{array}{ll}11 & 11 \\ 11\end{array}$

(2) Charged and maintained in accord with manufacturer's operating instructions. 


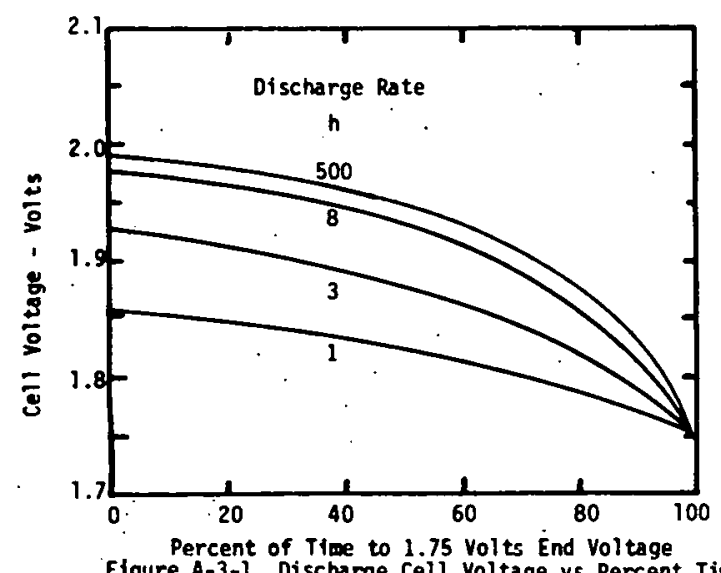

Figure A-3-1 Discharge Cell Voltage vs Percent Time to $1.75 \mathrm{~V}$ 1850-3700 Ah Lead-Calciun Cells, 1.215

specific Gravity. $25^{\circ} \mathrm{C}$.

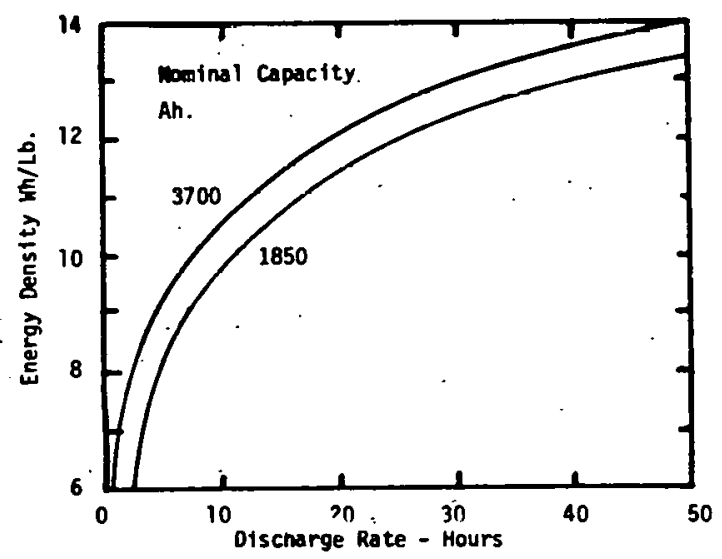

Figure A-3-2 Energy Density per Unit Weight, 1850-3700 Ah Lead-Calciu Cells, 1.215 Specific Gravity, $25^{\circ} \mathrm{C}$.

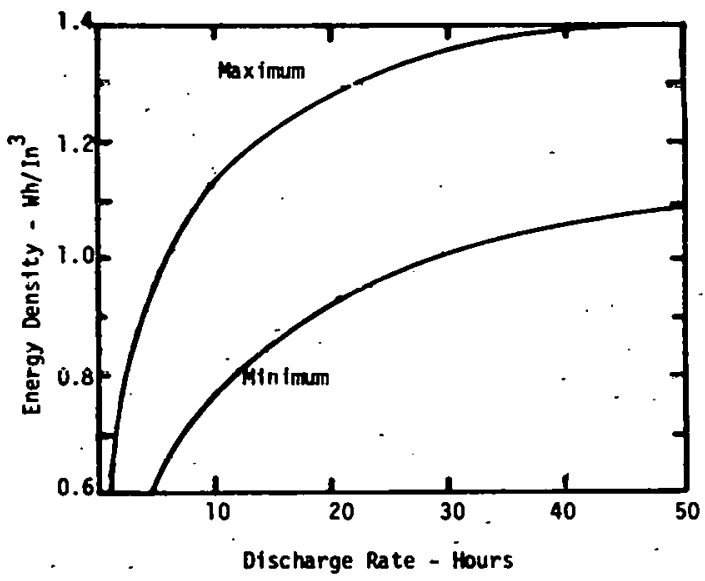

Figure A-3-3 Enerty Density per Unit Voluee vs. Discharge Rate. 1850-3700 Ah Lead-Caiclun Cells, 1.215 Specific Gevitity. $25^{\circ} \mathrm{C}$. 
TABLE A-4-1

Energy Density vs. Discharge Rate and Operating Temperature Lead-Antimony Flat Plate Cells

(50-200 Ah)

\begin{tabular}{|c|c|c|c|c|c|c|c|c|}
\hline \multirow{3}{*}{$\begin{array}{c}\text { Discharge } \\
\text { Rd le' } \\
\underline{h}\end{array}$} & \multirow{3}{*}{$\begin{array}{c}\text { Ccll } \\
\text { Capacity } \\
\text { (Numinal) } \\
\underline{\text { Ah }}\end{array}$} & \multirow{3}{*}{$\begin{array}{r}\text { Fnergy } \\
\text { Output } \\
\text { to } 1.75^{\circ} \mathrm{v} \\
\text { Wh } \\
\left(25^{\circ} \mathrm{C}\right)\end{array}$} & \multicolumn{6}{|c|}{$\begin{array}{l}\text { Energy Density at Operating } \\
\text { Temperaturc oc }\end{array}$} \\
\hline & & & \multicolumn{3}{|c|}{ Wh/Tb } & \multicolumn{3}{|c|}{ Wh/in 3} \\
\hline & & & $\underline{25}$ & $\underline{0}$ & -18 & $\underline{25}$ & $\underline{0}$ & -18 \\
\hline 500 & $\begin{array}{r}50 \\
100 \\
200\end{array}$ & $\begin{array}{r}249 \\
788 \\
1576\end{array}$ & $\begin{array}{r}6.6 \\
11.6 \\
13.0\end{array}$ & $\begin{array}{l}5.0 \\
8.7 \\
9.8\end{array}$ & $\begin{array}{l}2.6 \\
4.6 \\
5.2\end{array}$ & $\begin{array}{r}.29 \\
.93 \\
1.10\end{array}$ & $\begin{array}{l}.22 \\
.07 \\
.83\end{array}$ & $\begin{array}{l}.11 \\
.04 \\
.44\end{array}$ \\
\hline 8 & $\begin{array}{r}50 \\
100 \\
200\end{array}$ & $\begin{array}{r}191 \\
573 \\
1146\end{array}$ & $\begin{array}{l}5.0 \\
8.4 \\
9.5\end{array}$ & $\begin{array}{l}3.8 \\
6.3 \\
7.1\end{array}$ & $\begin{array}{l}2.0 \\
3.4 \\
3.8\end{array}$ & $\begin{array}{l}.23 \\
.68 \\
.78\end{array}$ & $\begin{array}{l}.17 \\
.51 \\
.59\end{array}$ & $\begin{array}{l}.09 \\
.27 \\
.30\end{array}$ \\
\hline 1 & $\begin{array}{r}50 \\
100 \\
200\end{array}$ & $\begin{array}{r}96 \\
282 \\
571\end{array}$ & $\begin{array}{l}2.5 \\
4.1 \\
4.7\end{array}$ & $\begin{array}{l}1.9 \\
3.1 \\
3.5\end{array}$ & $\begin{array}{l}1.0 \\
1.6 \\
1.9\end{array}$ & $\begin{array}{l}.11 \\
.33 \\
.39\end{array}$ & $\begin{array}{l}.08 \\
.25 \\
.29\end{array}$ & $\begin{array}{l}.04 \\
.13 \\
.16\end{array}$ \\
\hline \multirow[t]{4}{*}{ Notes: (1) } & $\begin{array}{c}\text { Cell } \\
\text { raparity } \\
\text { Ah } \\
\end{array}$ & \multicolumn{2}{|c|}{$\begin{array}{l}\text { Weight } \\
\text { Ib } \\
\end{array}$} & & $\begin{array}{l}\text { olume } \\
\text { in }^{3} \\
\end{array}$ & \multicolumn{3}{|c|}{$\begin{array}{l}\text { Module } \\
\text { Type }\end{array}$} \\
\hline & 50 & \multicolumn{2}{|c|}{38} & & 844 & \multicolumn{3}{|c|}{2 Cells in Series } \\
\hline & 100 & \multicolumn{2}{|c|}{68} & & 844 & \multicolumn{3}{|c|}{3 Cells in Series } \\
\hline & 200 & \multicolumn{2}{|c|}{121} & & 471 & \multicolumn{3}{|c|}{3 Cells in Series } \\
\hline
\end{tabular}

(2) Charged and maintained in accord wi th manufacturer's operating instructions. 


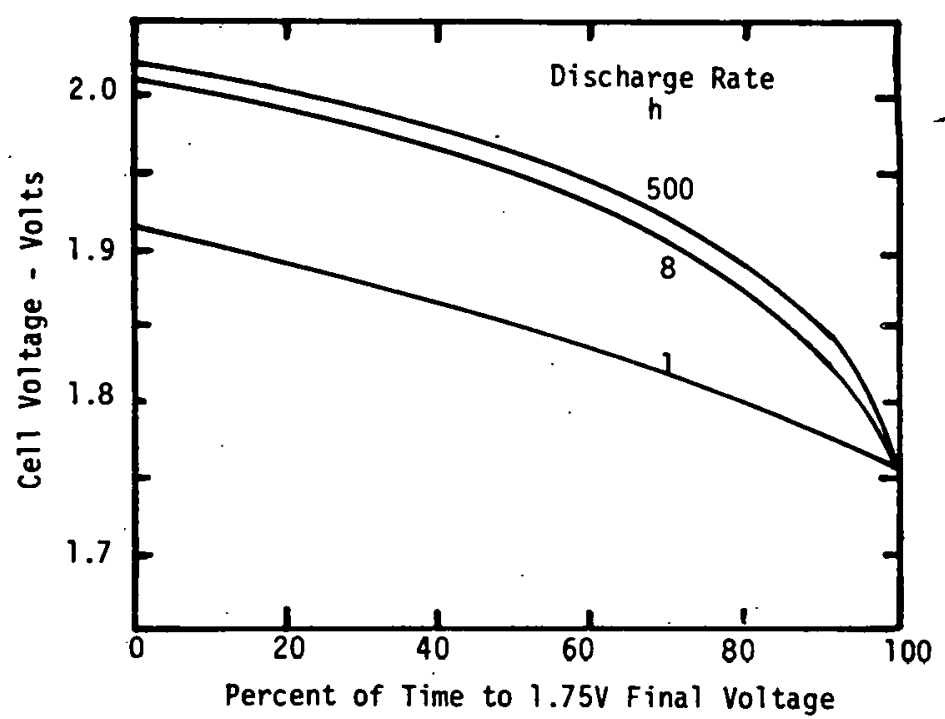

Figure A-4-1 Discharge Voltage vs Percent Time to 1.75V, 50-200 Ah Lead-Antimony

Pasted Flat Plate Cells, 1.215

Specific Gravity, $25^{\circ} \mathrm{C}$.

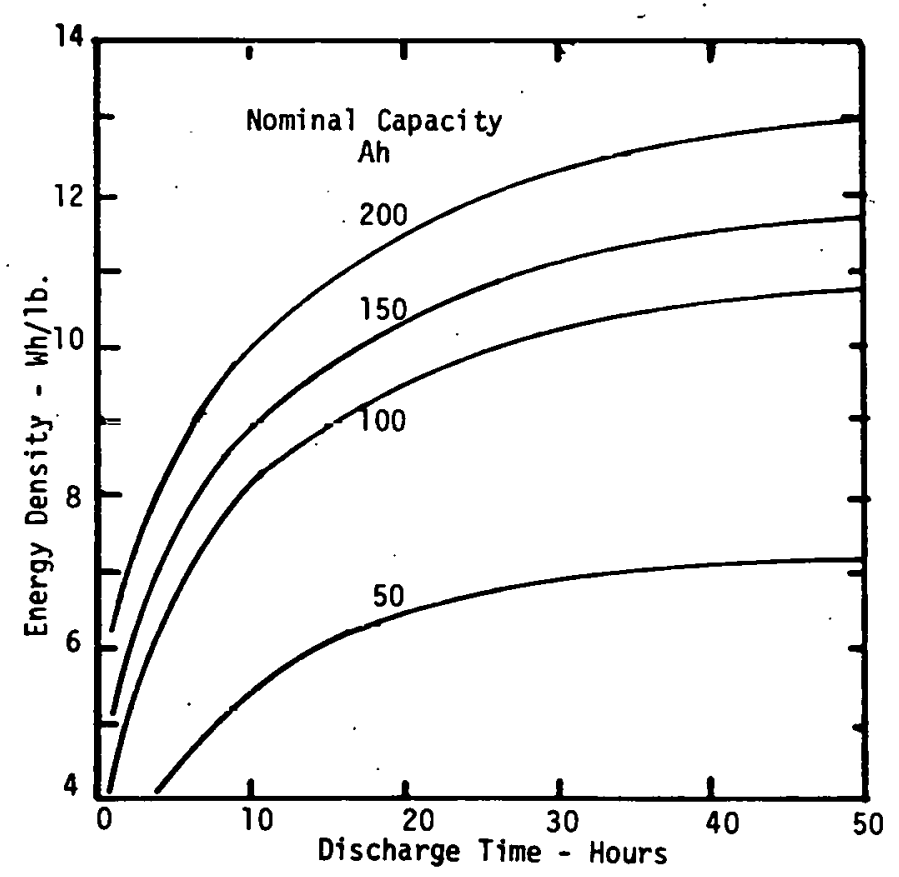

Figure A-4-2 Energy Density per Unit Weight vs Discharge Rate, 1-50 Hours, 50-200 Ah Flat Plate Lead-Antimony Cells. 1.215 Specific Gravity, $25^{\circ} \mathrm{C}$. 


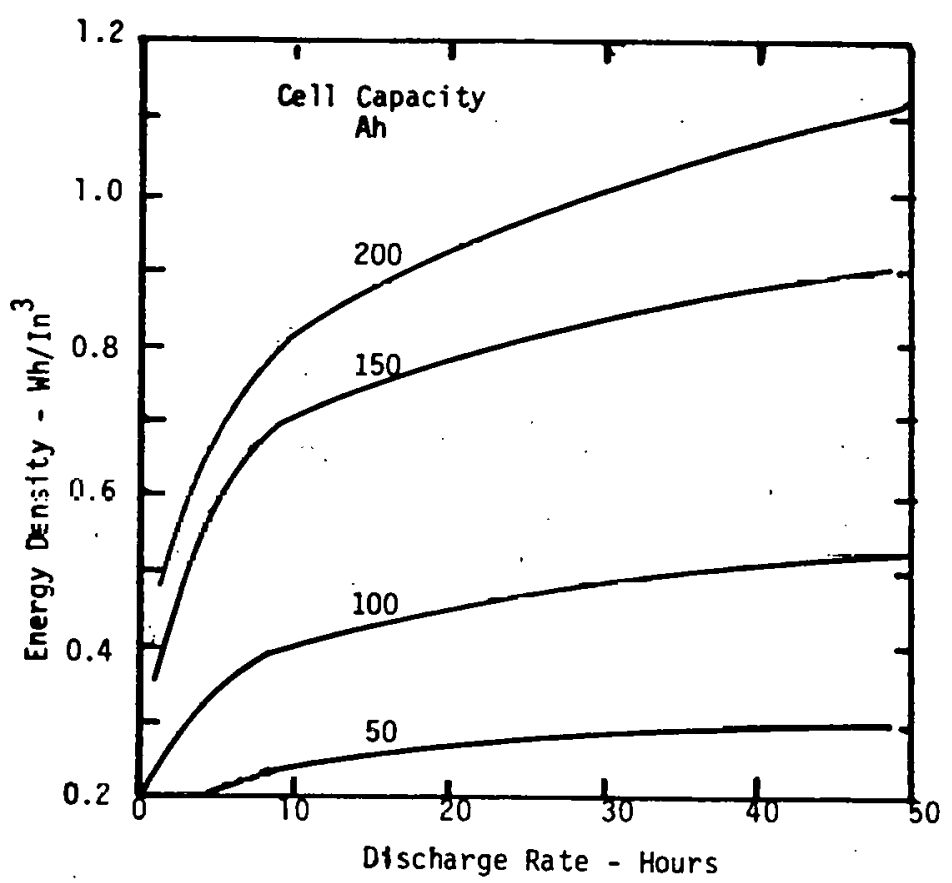

Figure A-4-3 Energy Density per Unit Volume vs

Discharge Rate, 1-50 Hours, 50-200 Ah

Flat Plate Lead-Antimony Cel1s, 1.215

Specific Gravity, $25^{\circ} \mathrm{C}$.

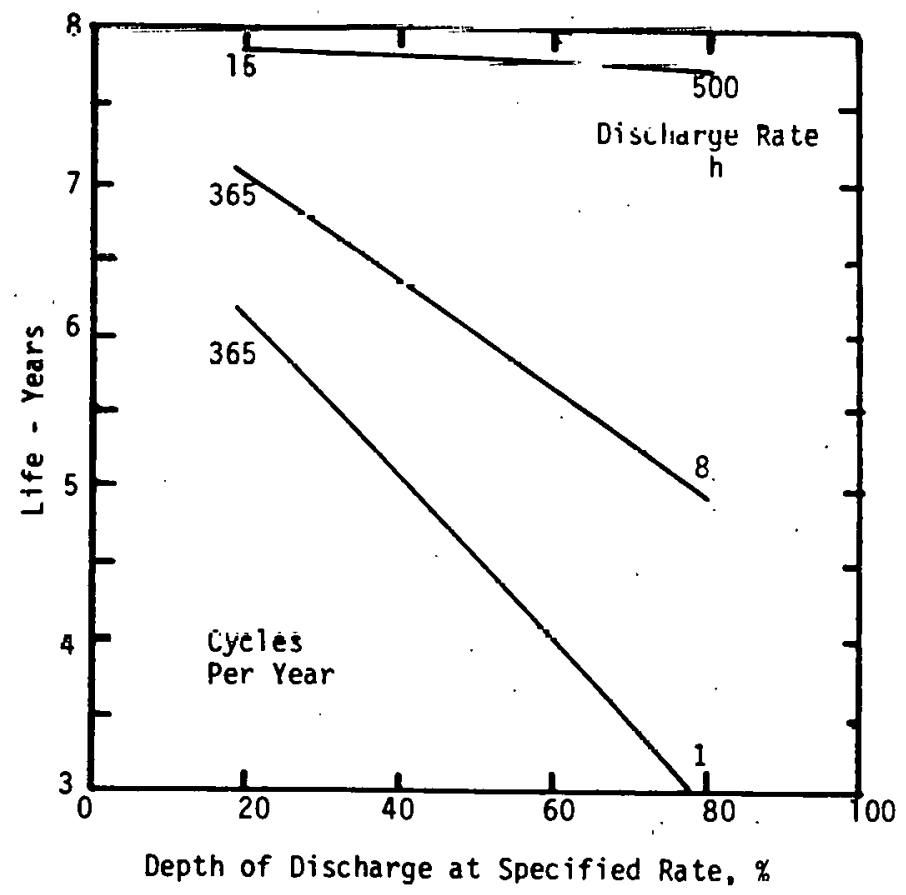

Figure A-4-4 Wet Cycle Life vs. Depth of Discharge, 50-200 Ah Flat Plate Lead-Antimony Cells, 1.215 Specific Gravity, $25^{\circ} \mathrm{C}$. 


\section{APPENDIX A-4 \\ LEAD-ANTIMONY PASTED FLAT PLATE CELLS $(50-200 \mathrm{Ah})$}

Table A-4-1 Energy Output and Energy Density per Unit Weight and Volume at $-18,0$ and $25^{\circ} \mathrm{C}$ vs Discharge Rate 1,8 and 500 Hours to 1.75 Volts per Cel1, 50-200 Ah Cells.

Figure A-4-1 Discharge Voltage vs Percent Time to End Voltage of 1.75 Volts at 1,8 and 500 Hour Rate, $25^{\circ} \mathrm{C}$.

Figure A-4-2 Energy Density per Unit Weight vs Discharge Rate, Hours, $25^{\circ} \mathrm{C}$.

Figure A-4-3 Energy Density per Unit Volume vs Discharge Rate, Hours, $25^{\circ} \mathrm{C}$.

Figure A-4-4 Wet Life and Cycle Life vs \% Depth of Discharge, $25^{\circ} \mathrm{C}$. 


\section{APPENDIX A-5 \\ LEAD-ANTIMONY PASTED FLAT PLATE CELLS \\ ( $110-900 \mathrm{Ah})$}

Table A-5-1 Discharge Voltage vs Discharge Rate. and Depth of Discharge, Motive Power Cells, $25^{\circ} \mathrm{C}$.

Table A-5-2 Energy Output, Energy Density vs Discharge Rate 3,8 and 72-Hours, Motive Power Cells, $25^{\circ} \mathrm{C}$.

Table A-5-3 Wet Life and Cycle Life vs Depth of Discharge, Motive Power lells, zb"c:

Table A-5-4 Discharge Capacity, Energy Output, and Energy Density, $25^{\circ} \mathrm{C}, 6$ Volt Electric Vehicle Type Batteries 


\section{TABLE $\quad A-5-1$}

Discharge Voltage vs Discharge Rate and Depth of Discharge Pasted Flat Plate Lead Antimony Industrial Truck Cells

$$
(150-1200 \mathrm{Ah})
$$

Discharge Depth
$?$
0
20
40
60
80
100

$7 \hat{r}=h$ Rale
2.10
2.05
2.02
1.98
1.92
1.75

$\begin{array}{cc}\text { Cel1 Voltage }- \text { Volts } \\ \text { 8-h Rátc } & 3-h \text { Rate } \\ & \\ 2.03 & 1 . y 9 \\ 2.00 & 1.95 \\ 1.97 & 1.92 \\ 1.94 & 1.88 \\ 1.88 & 1.82 \\ 1.75 & 1.75\end{array}$


Energy Output, Energy Density vs Discharge Rate 3, 8 and 72-Hours, $25^{\circ} \mathrm{C}$, Pasted Flat Plate Motive Power Cells

\begin{tabular}{|c|c|c|c|c|}
\hline $\begin{array}{l}\text { Discharge } \\
\text { Rate }\end{array}$ & $\begin{array}{r}\text { Capacity } \\
\text { to } 1.70 \text { VPC }\end{array}$ & $\begin{array}{ll} & \text { Energy } \\
\text { Output } \\
\text { to } 1.70 \text { VPC }\end{array}$ & $\begin{array}{r}\text { Er } \\
\text { Unit } \\
\text { Weight }\end{array}$ & $\begin{array}{l}\text { ity } \\
\text { Unit } \\
\text { Volume }\end{array}$ \\
\hline $\mathrm{h}$ & Ah & Wh & Wh/1b & Wh/ in $^{3}$ \\
\hline 72 & $\begin{array}{r}327 \\
655 \\
980 \\
1310 \\
240 \\
480 \\
720 \\
960 \\
195 \\
390 \\
585 \\
780\end{array}$ & $\begin{array}{r}650 \\
1295 \\
1940 \\
2595 \\
465 \\
930 \\
1400 \\
1860 \\
365 \\
735 \\
1100 \\
1465\end{array}$ & $\begin{array}{r}14.1 \\
16.0 \\
16.4 \\
16.9 \\
10.1 \\
11.5 \\
11.9 \\
12.1 \\
7.9 \\
9.1 \\
9.3 \\
9.5\end{array}$ & $\begin{array}{l}1.77 \\
1.94 \\
1.98 \\
2.02 \\
1.26 \\
1.39 \\
1.43 \\
1.45 \\
.99 \\
1.10 \\
1.12 \\
1.14\end{array}$ \\
\hline $\begin{array}{l}\text { Nominal } \\
\text {-Hour Rated } \\
\text { Capacity }\end{array}$ & $\begin{array}{c}\text { Cell } \\
\text { Weight }\end{array}$ & $\begin{array}{c}\text { Cell } \\
\text { Vol ume }\end{array}$ & & \\
\hline Ah & lbs & in $^{3}$ & & \\
\hline $\begin{array}{l}225 \\
450 \\
675 \\
900\end{array}$ & $\begin{array}{r}46 \\
81 \\
118 \\
154\end{array}$ & $\begin{array}{r}368 \\
669 \\
380 \\
1284\end{array}$ & & \\
\hline \multicolumn{5}{|c|}{ Includes cell share of steel battery tray. } \\
\hline
\end{tabular}


TABLE $A-5-3$

Wet Life and Cycle Life vs Depth of Discharge, $25^{\circ} \mathrm{C}$

Pasted Flat Plate Motive Power Cells

$\begin{array}{cccc}\begin{array}{c}\text { Depth of Discharge } \\ \% \text { 6-Hour Rated } \\ \text { Capacity }\end{array} & \begin{array}{c}\text { Cycle Life } \\ \text { Cycles per Day } \\ \text { (Estimated) }\end{array} & \begin{array}{c}\text { Wet Life } \\ \text { (Estimated) } \\ \text { Years }\end{array} & \begin{array}{c}\text { Accumulative Output } \\ \text { X Rated CapacityC }\end{array} \\ 10 & \text { Gu(n) } & 8.5 & 600 . \mathrm{C} \\ 30 & 4400 & 6 . & 1320 \mathrm{C} \\ 50 & 3250 & 4.5 & 1625 \mathrm{C} \\ 80 & 2000 & 3 . & 1600 \mathrm{C}\end{array}$

Note: Charged and maintained in accord with manufacturer's operating instructions. 
TABLE $A-5-4$

Discharge Capacity, Energy Output and Energy Density

$6 \mathrm{~V}$ Electric Vehicle Batteries, $25^{\circ} \mathrm{C}$

Lead-Antimony, Pasted Flat Plate Cells

\begin{tabular}{|c|c|c|c|c|c|}
\hline $\begin{array}{l}\text { Nominal } \\
\text { Capacity } \\
\text { 3-Hour } \\
\text { Rate } \\
\text { Ah } \\
\end{array}$ & $\begin{array}{c}\text { Discharge } \\
\text { Rate } \\
h\end{array}$ & $\begin{array}{c}\text { Discharge } \\
\text { Capacity } \\
\text { to } 1.70 \text { VPC } \\
\text { Ah } \\
\end{array}$ & $\begin{array}{c}\text { Energy } \\
\text { Output } \\
\text { to } 1.70 \mathrm{VPC} \\
\text { kWh } \\
\end{array}$ & $\begin{array}{l}\text { Energy } \\
\text { Per } \\
\text { Unit. Weight } \\
\text { Wh/lb. }\end{array}$ & $\begin{array}{l}\text { Density } \\
\text { Per } \\
\text { Unit Volume } \\
\text { Wh/in } \\
\end{array}$ \\
\hline 110 & $\begin{array}{r}72 \\
24 \\
12 \\
6 \\
3\end{array}$ & $\begin{array}{l}180 \\
165 \\
150 \\
135 \\
110\end{array}$ & $\begin{array}{l}1.09 \\
0.99 \\
0.89 \\
0.79 \\
0.64\end{array}$ & $\begin{array}{l}18.2 \\
16.6 \\
14.9 \\
13.2 \\
10.7\end{array}$ & $\begin{array}{l}1.56 \\
1.41 \\
1.27 \\
1.13 \\
0.91\end{array}$ \\
\hline 133 & $\begin{array}{r}72 \\
24 \\
12 \\
6 \\
3\end{array}$ & $\begin{array}{l}200 \\
185 \\
170 \\
155 \\
133\end{array}$ & $\begin{array}{l}1.22 \\
1.10 \\
1.01 \\
0.91 \\
0.77\end{array}$ & $\begin{array}{l}18.7 \\
16.9 \\
15.5 \\
14.0 \\
11.8\end{array}$ & $\begin{array}{l}1.74 \\
1.57 \\
1.44 \\
1.30 \\
1.10\end{array}$ \\
\hline
\end{tabular}

Notes: (1) Dimensions, volume, wet weight

Nominal

Capacity Volume Weight, Wet

$\begin{array}{llll}\mathrm{Ah} & \frac{\mathrm{in}^{3}}{110} & \frac{1 \mathrm{~b} .}{700} & 59.8 \\ 13.3 & & 700 & 65.2\end{array}$

(2) Cycle life: about 500 cycles at $80 \%$ depth in 500 days wet $1 \mathrm{ife}$ in ambient conditions. 


\section{APPENDIX A-6 \\ LEAD-ANTIMONY TUBULAR POSITIVE CELLS AND BATTERIES \\ (220-1820.Ah)}

Figure A-6-1 Discharge Voltage vs Percent Time to End Voltage of 1.75 Volts per Cell at $25^{\circ} \mathrm{C}$ at 1,8 and 500 Hour Discharge Rate.

Figure A-6-2 Wet Cycle Life vs Percent Depth of Discharge, 220-400 Ah Tubular Positive Cells, 1.28 Specific Gravity, $25^{\circ} \mathrm{C}$.

Table A-6-1 Energy Output 6-Hour Rate, Energy Density vs Operating Temperature, $-18,0$ and $25^{\circ} \mathrm{C}$ for $12 \mathrm{~V} 110$ torized Hand Truck Batteries.

Table. A-6-2 Energy Output, Average Voltage, Energy Density vs Discharge Rate, $1,8,100$ and 500 Hours $25^{\circ} \mathrm{C}$ General Purpose Tubular Positive Cells, 760-1820 Ah.

Table A-6-3 Energy Output, Energy Density vs Discharge Rate 6, 12 and 72 -Hours, $25^{\circ} \mathrm{C}$. Tubular Positive Motive Power Cells, 510-1200 Ah.

Table A-6-4 Wet Life and Cycle Life vs Depth of Discharge, Tubular Positive Industrial Truck Cells, $25^{\circ} \mathrm{C}$. 


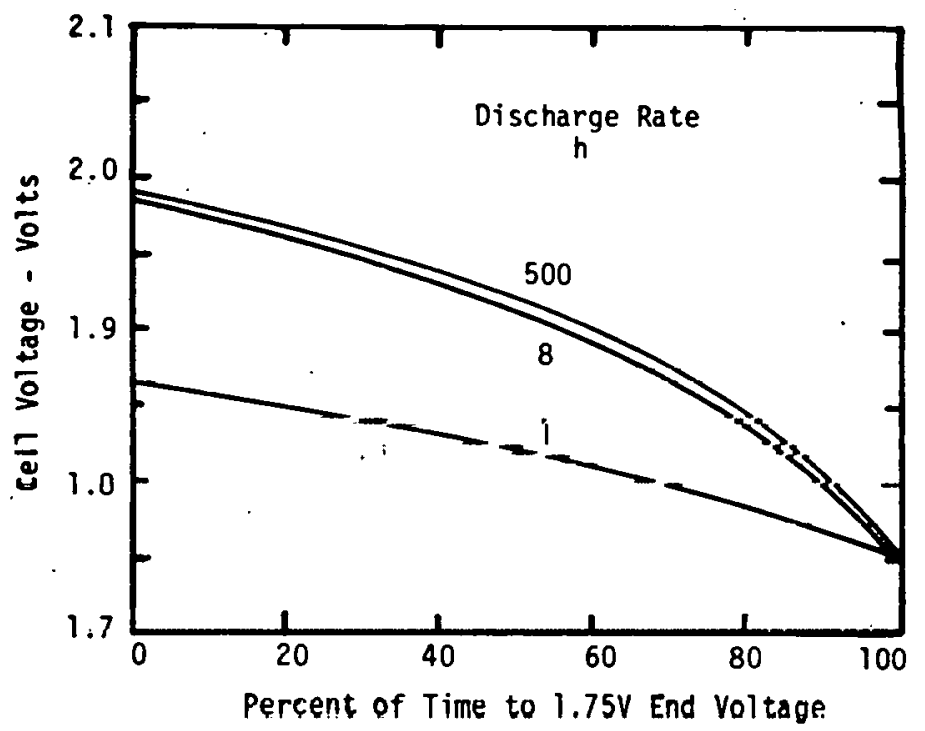

Figure A-6-l Cell Discharge Voltage vs Percent Time to $1.75 \mathrm{~V}$ End Voltage, 220-400 Ah Tubular Positive LeadAntimony Cells, 1.280 Specific Gravity, $25^{\circ} \mathrm{C}$.

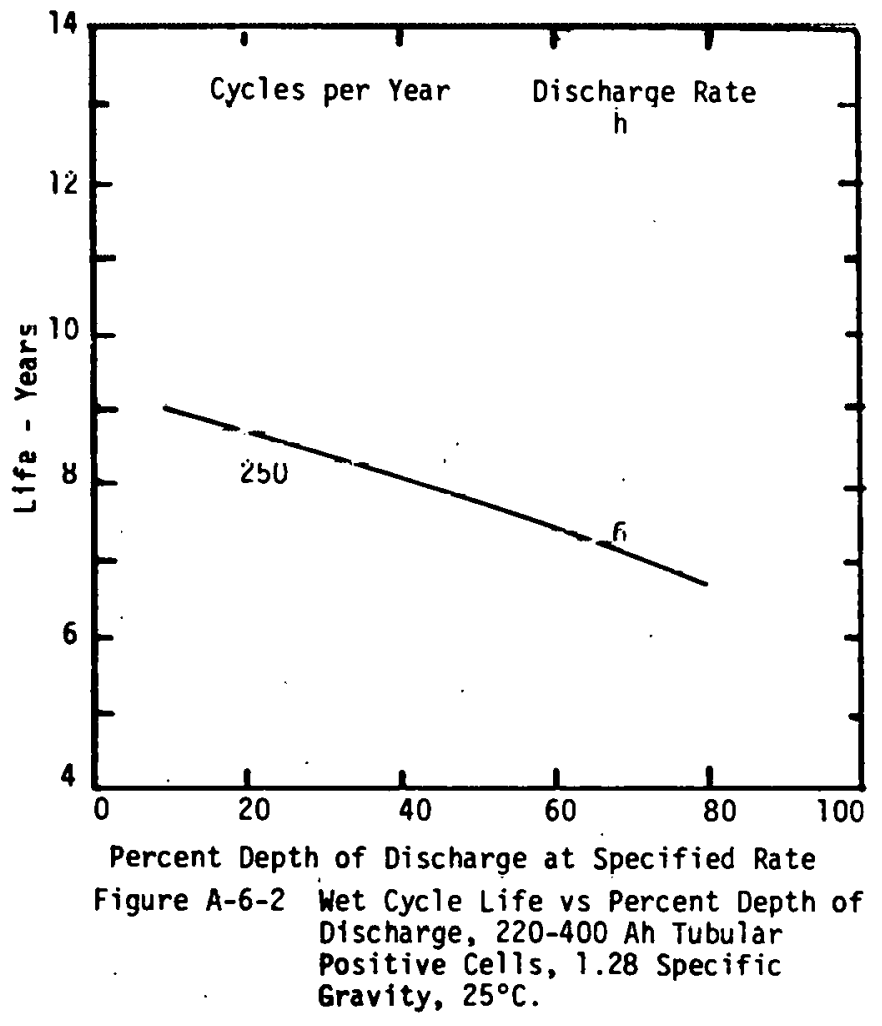


Energy Output 6-Hour Rate, Energy Density vs Operating Temperature, $-18,0$ and $25^{\circ} \mathrm{C}$

$12 \mathrm{~V}$ Motorized Hand Truck Batteries

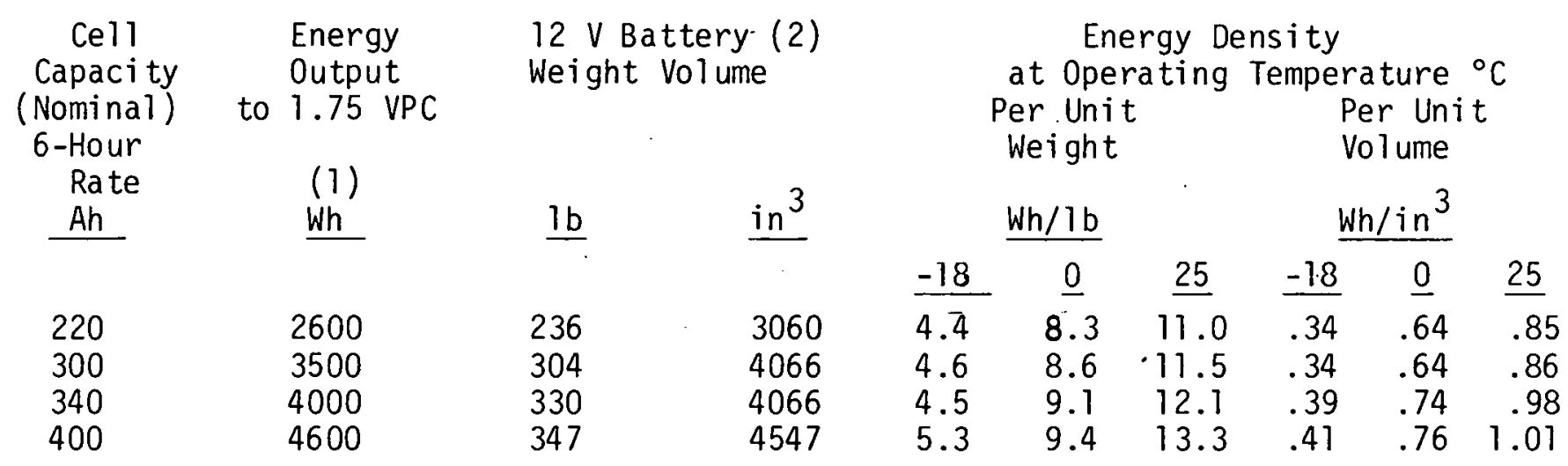

Notes: (1) Batteries discharged at $6-\mathrm{h}$ rate to $10.5 \mathrm{~V}$ at $25^{\circ} \mathrm{C}$.

(2) Nine plate cells assembled as $12 \mathrm{~V}$ battery in a steel tray.

(3) Reference: Exide Lead Acid Batteries for Industrial Trucks, Section 20.02, page 1 .

(4) Charged and maintained in accord wi th manufacturer's operating instructions. 
TABLE $A-6-2$

Energy Output, Average Voltage, Energy Density vs Discharge Rate, $25^{\circ} \mathrm{C}$ General Purpose Tubular Positive

Lead-Antimony Cells

(760-1820 Ah)

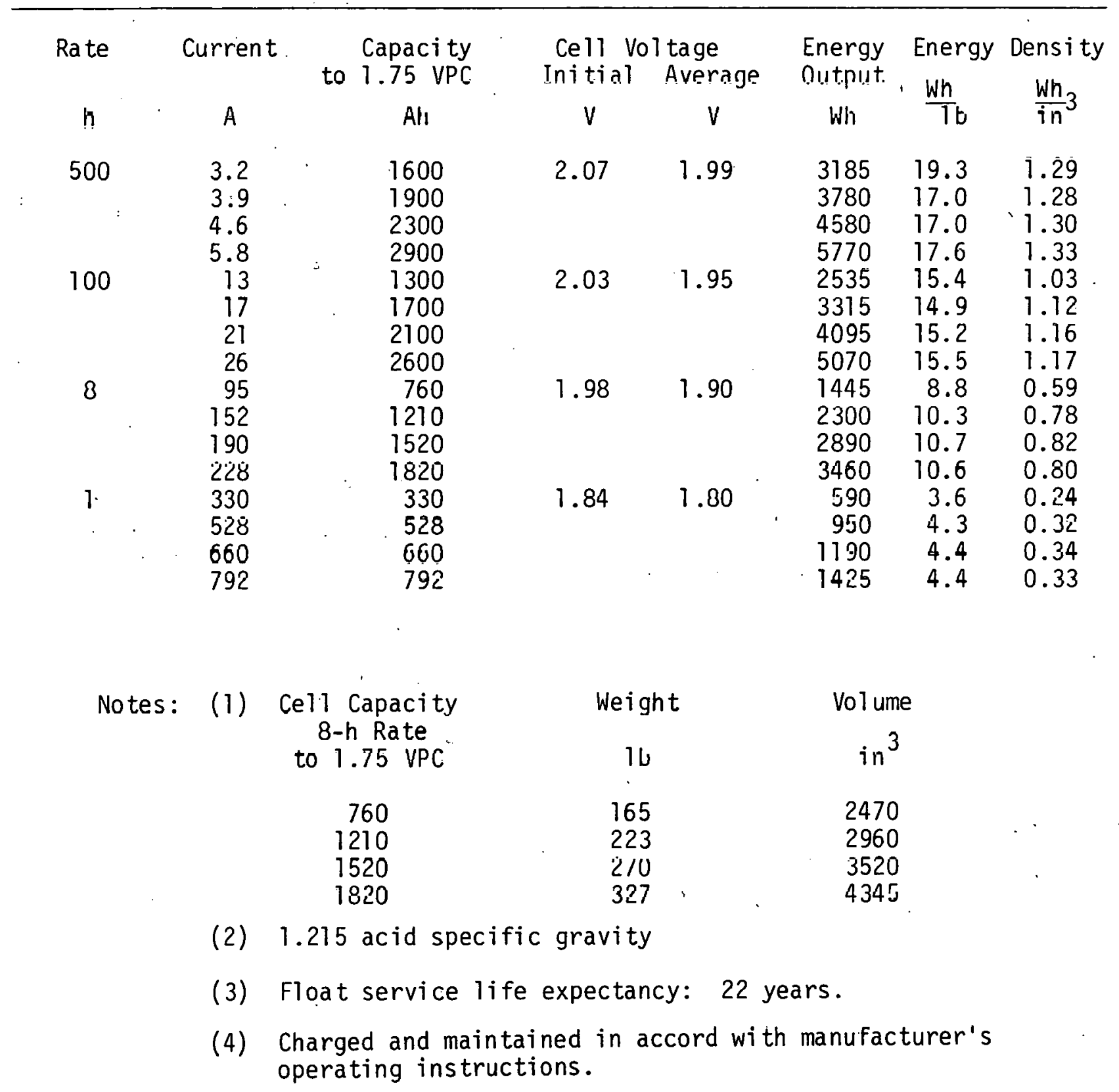


TABLE $A-6-3$

Energy Output, Energy Density vs Discharge Rate, $25^{\circ} \mathrm{C}$ Tubular Positive Lead-Antimony Motive Power Cells

(510-1200 Ah)

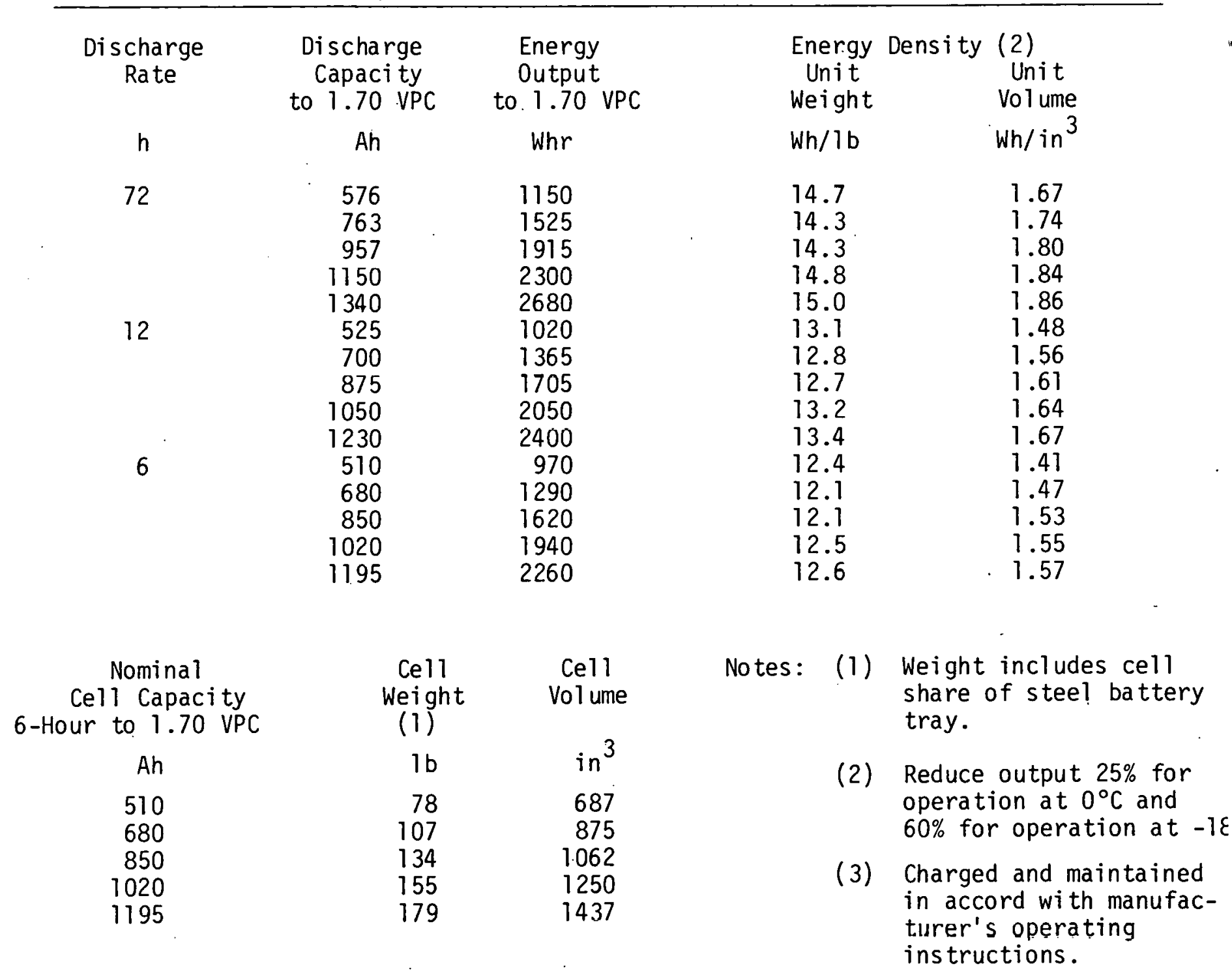




\section{TABLE $A-6-4$}

Wet Life and Cycle Life vs Depth of Discharge, $25^{\circ} \mathrm{C}$ Tubular Positive Industrial Truck Cells

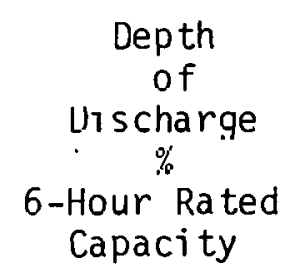

10

30

50

80

\author{
Cycle \\ Life \\ 2 c.yciles \\ per \\ Day \\ (Estimated)
}

4600

3400

2450

1500

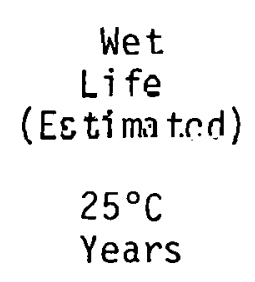

7

5

4

3
Accumulative Output $X$ Rated Capacity C

(Es Lillld LCU)
(1)
Ah

$460 \mathrm{C}$

$1020 \mathrm{C}$

$1225 \mathrm{C}$

$1200 \mathrm{C}$

Notes: (1) Charged and maintained in accord with manufacturer's operating ins tructions. 


\section{APPENDIX B}

TYPICAL PERFORMANCE CHARACTERISTICS OF NICKEL-CADMIUM POCKET PLATE CELLS

Work Performed for

The U.S. Department of Energy Sandia National Laboratories

Albuquerque, New Mexico 87185

Under Contract No. 13-2202 


\section{APPENDIX B \\ TYPICAL PERFORMANCE CHARACTERISTICS OF NICKEL-CADMIUM POCKET PLATE CELLS}

Data is summarized in this appendix of the discharge and charge characteristics of a typical vented, intermediate rate, pocket plate nickel-cadmium cell. High rate and low rate cells are also available from manufacturers and can be considered by the system designer. High rate cells will have higher voltages on high rate discharges like starter loads. Low rate cells will have superior energy density and longer life.

Data for hermetically sealed sintered nickel-cadmium cells has not been enclosed because of the higher cast of these cells; however, this data can be supplied by the battery manufacturer upon request. 


\section{APPENDIX B-1 \\ TYPICAL PERFORMANCE CHARACTERISTICS OF NICKEL-CADMIUM POCKET PLATE CELLS}

Table B-1-1 Discharge Voltage vs. Discharge Rate and Depth of Discharge, $25^{\circ} \mathrm{C}$.

Table B-l-2 Charge Efficiency of Pocket Plate Nickel-Cadmium Ce $11 \mathrm{~s}, 25^{\circ} \mathrm{C}$.

Table B-1-3 Energy Output, Energy Density vs. Discharge Rate $1,5,10,50,500$ Hours, 7.5-480 Ah Ce11s, $25^{\circ} \mathrm{C}$.

Table B-1-4 Charged Stand Loss Rates at 22 and $49^{\circ} \mathrm{C}$. 
TABLE $B-1-1$

Discharge Voltage vs Discharge Rate and Depth of Discharge

Pocket Plate Nickel-Cadmi um Cells, $25^{\circ} \mathrm{C}$

$\begin{array}{rcccc}\begin{array}{c}\text { Discharge } \\ \text { Capacity } \\ \% \text { of } \\ \text { 5-h Rate }\end{array} & \begin{array}{c}\text { Co-h Rate } \\ \text { Volts }\end{array} & \begin{array}{c}\text { 10-h Rate } \\ \text { Volts }\end{array} & \begin{array}{c}\text { 5-h Rate } \\ \text { Volts }\end{array} & \begin{array}{c}\text { 1-h Rate } \\ \text { Vol ts }\end{array} \\ 0 & 1.35 & 1.34 & 1.32 & 1.20 \\ 20 & 1.30 & 1.28 & 1.25 & 1.12 \\ 40 & 1.28 & 1.26 & 1.23 & 1.08 \\ 60 & 1.26 & 1.24 & 1.21 & 1.03 \\ 80 & 1.24 & 1.22 & 1.20 & 0.80 \\ 100 & 1.18 & 1.15 & 1.00 & --\end{array}$

TABLE B-1-2

Charge Efficiency of Pocket Plate

Nickel Cadmium Cells, $25^{\circ} \mathrm{C}$

(31\% KOH Electrolyte)

$\begin{array}{ccc}\begin{array}{c}\text { Discharge } \\ \text { Output }\end{array} & \begin{array}{r}\text { Recharge Required to } \\ \text { Restore Output Capacity } \\ \text { \% of Rated } \\ \text { 5-h Caparit.y (1) }\end{array} & \begin{array}{c}\text { Overcharge } \\ \text { Required }\end{array} \\ 5-h \text { Rated } & & \% \\ 100 & 140 & 40 \\ 80 & 120 & 40 \\ 60 & 98 & 38 \\ 40 & 75 & 35 \\ 20 & 50 & 30 \\ 10 & 30 & 20\end{array}$

(1) Recharge time: 20 hours minimum. 

Energy Output, Energy Density vs. Discharge Rate, $25^{\circ} \mathrm{C}$ Pocket Plate Nickel Cadmium Cells $(7.5$ - 480 Ah)

\begin{tabular}{|c|c|c|c|c|}
\hline \multirow[b]{2}{*}{$\begin{array}{l}\text { Discharge } \\
\text { Ra te }\end{array}$} & \multirow{2}{*}{$\begin{array}{c}\text { Cell } \\
\text { Capacity } \\
\text { (Nominal) } \\
5-\mathrm{h} \text { to } 0.9 \mathrm{~V}\end{array}$} & \multirow[b]{2}{*}{$\begin{array}{l}\text { Energy } \\
\text { Output } \\
\text { to } 0.9 \mathrm{~V}\end{array}$} & \multicolumn{2}{|c|}{ Energy'Dens ity } \\
\hline & & & $\begin{array}{l}\text { Unit } \\
\text { Weight }\end{array}$ & $\begin{array}{l}\text { Unit } \\
\text { Vol ume }\end{array}$ \\
\hline$\underline{h}$ & Ah & Wh & Wh/lb. & Wh/in \\
\hline 500 & 7.5 & 11.2 & 6.2 & 0.31 \\
\hline 50 & & 11.0 & 6.1 & 0.30 \\
\hline 10 & & 9.6 & 5.3 & 0.26 \\
\hline & & 8.9 & 4.9 & 0.24 \\
\hline 1 & & 6.3 & 3.5 & 0.17 \\
\hline 500 & 85 & 129 & 14.7 & 0.64 \\
\hline 50 & & 125 & 14.2 & 0.63 \\
\hline 10 & & 110 & 12.5 & 0.55 \\
\hline & & 103 & 11.7 & 0.52 \\
\hline 1 & & 72 & 8.2 & 0.36 \\
\hline 500 & 300 & 450 & 20.6 & 1.20 \\
\hline 50 & & 440 & 20.2 & 1.17 \\
\hline 10 & & 385 & 17.7 & 1.03 \\
\hline 5 & & 360 & 16.5 & 0.96 \\
\hline 1 & & 250 & 11.5 & 0.67 \\
\hline & 480 & & 20.8 & \\
\hline 50 & & 690 & 20.2 & 1.21 \\
\hline 10 & & 605 & 17.7 & 1.07 \\
\hline 5 & & 565 & 16.5 & 0.99 \\
\hline 1 & & 395 & 11.5 & 0.70 \\
\hline
\end{tabular}

\section{Cell Nominal Capacity}

$\underline{\text { Ah }}$

7.5
85
300
480

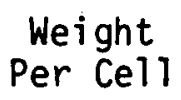

lb.

$$
\begin{array}{r}
1.8 \\
8.8 \\
21.8 \\
34.2
\end{array}
$$

Vol ume

Per Cell

in 3

36.5

199

375

568

Note: Charged and maintained in accord with manufacturer's operating instructions. 
TABLE $B-1-4$

Charged Stand Loss Rates

Pocket Plate Nickel Cadmi um Cells

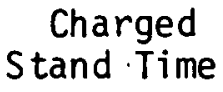

Months

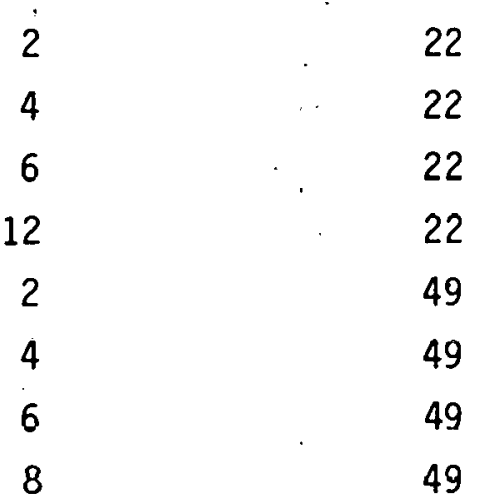

$$
\begin{aligned}
& \text { Capacity } \\
& \text { Retained }
\end{aligned}
$$

i

87

82

80

78

62

40

24

10
Capacity Loss Rate

\&day

0.22

0.15

0.11

0.06

0.63

0.50

0.42

0.38 
DISTRIBUTION :

DOE/TIC-4500-R69, UC-94ca (336)

Aerospace Corporation

20030 Century Blvd.

Germantown, MD 20767

ATTN: I. B. Weinstock

Applied Physics Laboratory

John Hopkins Road

Laurel, MD 20810

ATTN: W. R. Powell

Argonne National Laboratory

9700 South Cass Avenue

Argonne, IL 60439

ATTN: N. P. Yao

R. O. Loutfy

Battelle, Columbus Laboratories

505 King Avenue

Columbus, OH 43201

ATTN: J.E. Clifford

Bechtel National, Inc.

P. O. Box. 3965

San Francisco, CA 94119

ATTN: W. J. Stolte

S. W. Eckroad

Bell Laboratories

600 Mountain Avenue

Murray Hill, NJ 07974

ATTN: D. O. Feder

Dr. Frank J. Biondi, Conoultant

74 Ridge Drive

Livingston, NJ 07039

Dr. Per Bro

Route 7, HydePark Estates

Santa Fe, NM 87501

Brookhaven National Laboratory

Upton, NY 11973

ATTN : J. McBreen

Exide Management and Technology Co. 19 West College Avenue

P. O. Box 336

Yardley, PA 19067

ATTN : J.J. Kelly (10)

D. T. Ferreli, Jr.

Jet Propulsion Laboratory

4800 Oak Grove Drive

Pasadena, CA 91103

ATTN: J. W. Farrar

R. V. Powell

J. L. Hesse

Lawrence Berkeley Laboratory

University of California

Berkeley, CA 94720

ATTN : F. McLarnon

Lawrence Livermore Laboratory

P. O. Box 808

Livermore, CA 94550

ATTN: E. Behrin

Massachusetts Institute of

Technology

Lincoln Laboratory

P. O. Box 73

Lexington, MA 02173

ATTN: M. D. Pope

NASA-Lewis Research Center

21000 Brookpark Roa.d

Cleveland, $\mathrm{OH} \quad 44135$

ATTN : A. W. Nice

L. H. Thaller

Naval Weapons Support Center Electrochemical Power Sources Div Crarie, IN 47522

ATTN: D. E. Mains

SES, Incorporated

Tralee Industrial Park

Newark, DE 19711

ATTN: W. J. Kaszeta

Solar Energy Research Institute 1536 Cole Buulevara

Golden, Co 80401

ATTN : F. Baylin

Dr: Philip Symons, Consultant

251 E. Lincoln Road

Birmi.ngham, MI 48009 
United States coast Guard

Research and Development Center Avery Point

Groton, CT 06340

ATTN : S. E. Trenchard

U. S. Department of Energy

1000 Independence Avenue, SW

Forestal Building, M.S. 6B-025

Washington, DC 20585

ATTN : John J. Brogan

U. S. Department of Energy

1000 Independence Avenue, SW

Forestal Bulldirg, Rm-1G066

Washingturl, DC 20585

ATTN: A. R. Landgrebe (10)

W. H. Webster

V. Rabl

U. S. Department of Energy

P. O. Box 5400

Albuquerque, NM 87115

ATTN: D. L. Plymale

U. S. Department of Energy

9700 South Cass Avenue

Axgonne, TI $6 \cap 439$

$\triangle T T N$ : W. R. Frost

U. S. Department of Energy

20 Massachusetts Avenue, NW

Washington, DC 20585

ATTN: T., Rogers

U. S: Department of Energy

Photovoltaic Branch

1000 Independence Avenue; SW

Forestal Building

Washington, DC 20585

ATTN: A. Clorfeine

M. J. Katz

U. S. Department of Energy

1000 Independence Avenue, SW

Forestal Building, Rm-5G033

Washington, DC 20585

ATTN: R. F. Santopietro
2500 J. C. Crawford

2520 H. J. Saxton

2522 R. D. Wehrle

2523 R. K. Quinn

2525 R. P. Clark

2525

8214

3141

3151

D. M. Bush

P. A. Childers

L. J. Erickson (5)

W. L. Garner (3)

For DOE/TIC (Unlimited Releas 
